九州大学学術情報リポジトリ

Kyushu University Institutional Repository

バングラデシュにおけるツムギアリ0ecophy l la smaragdinaの系統地理（ハチ目アリ科）

モハメッド マムヌール ラーマン

http://hdl. hand le. net/2324/1959176

出版情報 : Kyushu University，2018，博士（農学）， 課程博士 バージョン：

権利関係 : 


\title{
Phylogeography of weaver ant, Oecophylla smaragdina, in Bangladesh (Hymenoptera: Formicidae)
}

\author{
Md. Mamunur Rahman
}

2018 


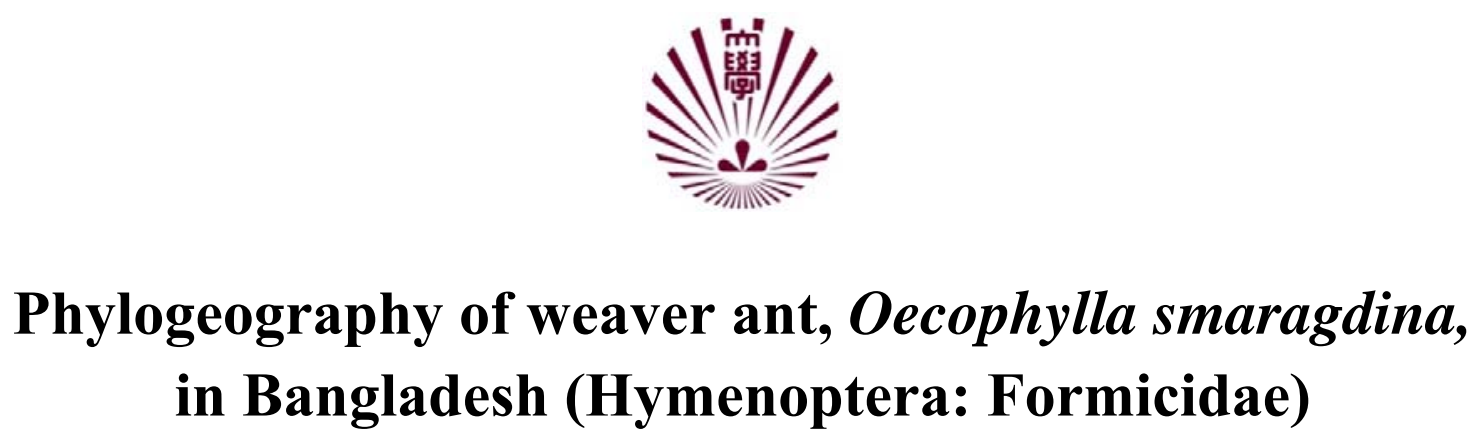

by

\section{Md. Mamunur Rahman}

A dissertation submitted to the Graduate School of Bioresource and

Bioenvironmental Sciences, Kyushu University, Japan

\section{DOCTOR OF PHILOSOPHY}

Graduate School of Bioresource and Bioenvironmental Sciences

Kyushu University

Japan 


\section{AbstraCT}

The weaver ant species, Oecophylla smaragdina, is widely distributed from India through Southeast Asia to northern Australia including many tropical Western Pacific islands. The ant is arboreal observed in natural forests, fruit orchards and homestead woodlands, and is one of the important biological control agents. A recent phylogenetic study of O. smaragdina showed that the species is divided into 7 groups based on mtDNA and that the Bangladesh populations belong to SE Asian mainland clade despite of its geographical proximity to India. However, the samples analyzed from Bangladesh were limited and distribution pattern of Bangladeshi populations was not clearly presented.

The present study aims to reveal the phylogeographic aspect of $O$. smaragdina in Bangladesh including phylogenetic analysis, haplotype network analysis and divergence time estimation as well as hybridization detection based on extensive materials. The sampling was executed according to zonation of 5 areas which are demarcated by 3 main rivers during the years 2013 to 2017 . Ninety five colonies from 87 localities of 47 Districts were collected. The molecular analyses were carried out using 2 mitochondrial loci: Cytochrome b oxidase subunit 2 (Cytb) consisting of $507 \mathrm{bp}$ and Cytochrome c oxidase subunit I (COI) consisting of $639 \mathrm{bp}$.

The possibility of occurring hybridization of $O$. smaragdina in the zone of contact was examined by using LW Rh of nuclear DNA and microsatellite markers.

The phylogenetic analysis of 84 colonies revealed that 47 are the Indian clade (Indian type) and 37 are the SE Asian mainland clade (SE Asian type). The distribution of mtDNA types showed that the western parts of Bangladesh is predominantly occupied by the Indian type, whereas, the eastern part was dominated by the SE Asian type, and the central parts is the mixture of both types. The haplotype network analysis indicated that a total of 25 haplotypes 
were identified in Bangladesh based on COI genes, comprises 13 and 12 of Indian and SE Asian types, respectively. The divergence time analysis in Bangladesh populations, resulted that Indian type diverged ca. 2.2 Ma and SE Asian type diverged ca. 0.20 Ma corresponding to early to late Pleistocene. Two microsatellite markers, MS 6.45 and MS 8.24 possibly detected identical allele between Indian and SE Asian types of Oecophylla population in Bangladesh. Nuclear gene sequences from LW Rh region showed inconsistency of Indian and SE Asian types from two colonies of the overlapped zone. Discordance between mitochondrial and nuclear DNA genes suggests the possibility of hybridization in the zone of contact.

The results of the study suggest a scenario of dispersal: 1) before Last Glacial Maximum (LGM), the haplotypes observed in Bangladesh would be already established; 2) during the LGM, the Bengal Delta supposed to be vacant for Oecophylla smaragdina distribution because the northern limit of the species would be located down to the south; 3) after the LGM, the isolated populations in southern refuge areas of India and SE Asia extended to south, and in Bengal Delta the Indian type populations came from west and the SE Asian type populations from east; 4) when the Indian type populations and the SE Asian type populations contacted in the Bengal Delta, each of the types already contained several haplotypes of mtDNA, and reproductive isolation is not established. 


\section{CONTENTS}

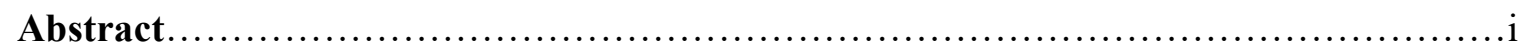

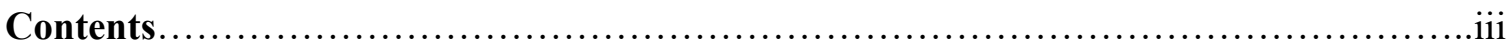

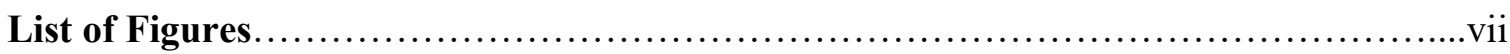

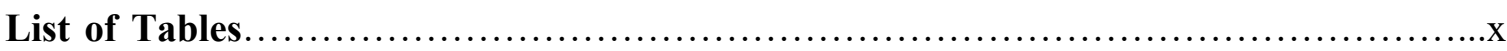

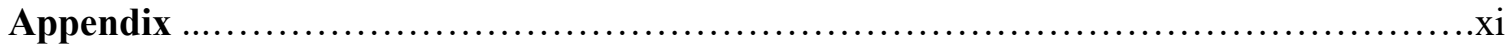

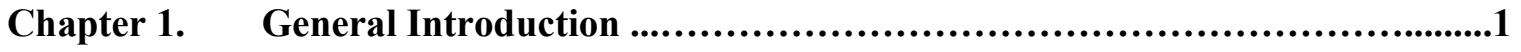

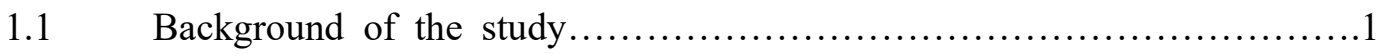

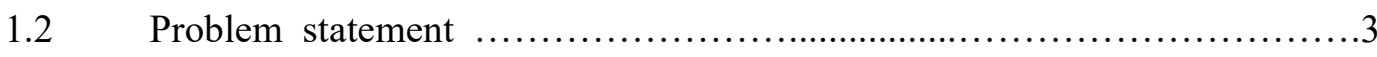

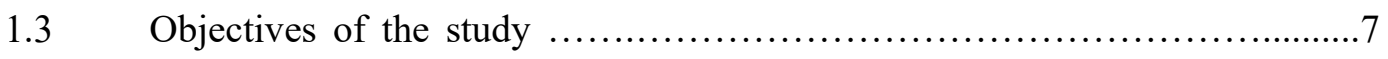

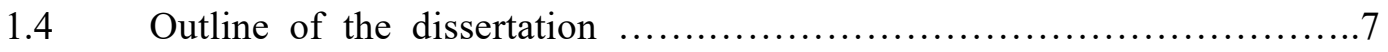

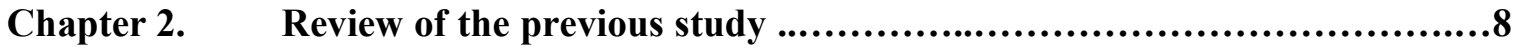

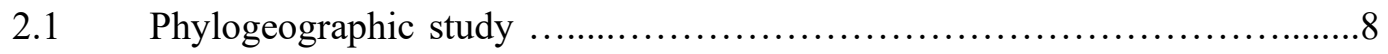

2.1.1 Mitochondrial DNA analysis ................................... 8

2.1.2 Nuclear DNA for detecting hybridization ...................................10

2.1.3 Microsatellite study for determining heterozygosity ..............12

2.1.4 Phylogenetic tree for inferring phylogeography $\ldots \ldots \ldots \ldots \ldots \ldots \ldots 12$

2.1.5 Phylogeographic feature in the study at East Asia ...................14

2.2 Taxonomy, distribution and divergence history of Oecophylla ..............15

2.2.1 Taxonomy of $O$. smaragdina .................................. 15

2.2.2 Biology of $O$. smaragdina ..................................20

2.2.3 Distribution of $O$. smaragdina and the factors affecting such 
2.2.4 Divergence time of $O$. smaragdina ............................23

2.3 Geology of Bangladesh and its importance for phylogeographic

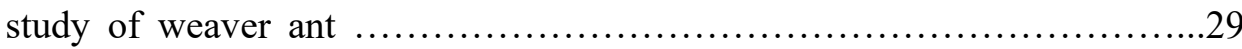

2.4 Phylogenetic study of $O$. smaragdina in Asian continent ...................32

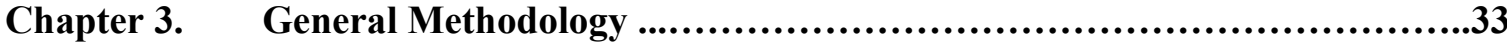

3.1 Sampling of Oecophylla smaragdina in Bangladesh .......................33

The setting of the study sites .........................................33

Localities of $O$. smaragdina sampling .................................36

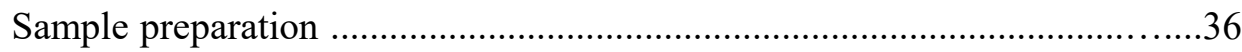

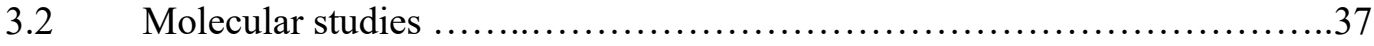

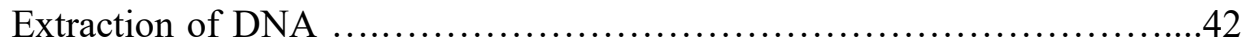

PCR (Polymerase chain reaction) $\ldots \ldots \ldots \ldots \ldots \ldots \ldots \ldots \ldots \ldots \ldots \ldots \ldots \ldots . \ldots \ldots 2$

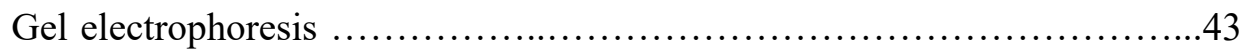

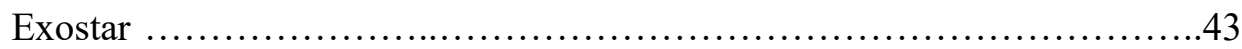

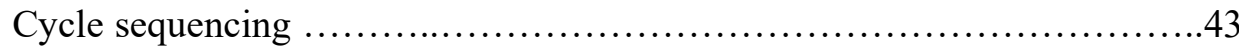

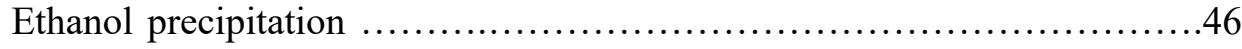

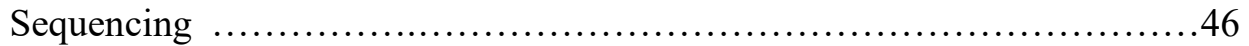

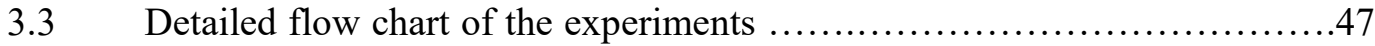

Chapter 4. Phylogenetic relationship inferred from mitochondrial DNA of Oecophylla smaragdina in Bangladesh .....................................................53

4.1 Revealing the distribution pattern of O. smaragdina in Bangladesh ...... 51

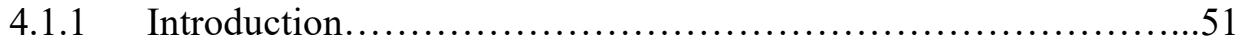


4.1.2 Materials and methods ......................................53

Sampling and preparation of specimens ........................53

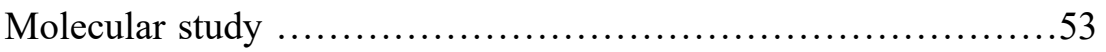

Phylogenetic inferences ...................................54

4.1.3 Results and discussions ....................................55

Bayesian phylogenetic tree inferences .......................55

Summary of distribution pattern ............................57

4.2 Haplotypes and its network distribution of O. smaragdina in Bangladesh

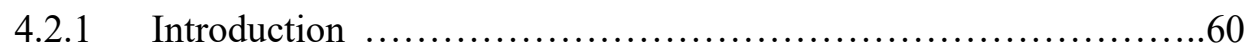

4.2.2 Materials and Methods ....................................61

Sampling and preparation of specimens $\ldots \ldots \ldots \ldots \ldots \ldots \ldots \ldots \ldots 61$

Molecular data collection..$\ldots \ldots \ldots \ldots \ldots \ldots \ldots \ldots \ldots \ldots \ldots \ldots \ldots \ldots \ldots$

Haplotype network analysis................................62

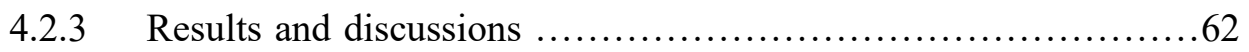

Oecophylla. smaragdina haplotypes in Bangladesh ...............62

Haplotype network study $\ldots \ldots \ldots \ldots \ldots \ldots \ldots \ldots \ldots \ldots \ldots \ldots \ldots . \ldots \ldots$

\section{Chapter 5. Divergence and contact of Indian and SE Asian types of Oecophylla} smaragdina in Bangladesh ............................................................68

5.1 Divergence time estimation of O. smaragdina in Bangladesh .....................68

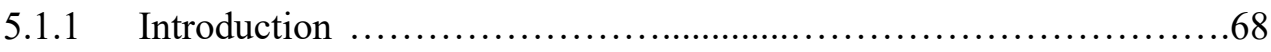

5.1.2 Materials and methods ..........................................69

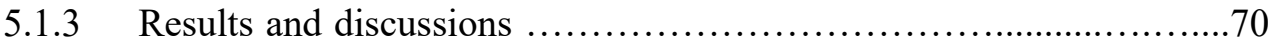

5.2 Hybridization scenario of Indian and SE Asian types of weaver ant using long 
wavelength rhodopsin (LW Rh) and microsatellite markers.

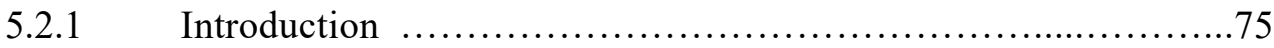

5.2.2 Materials and methods .......................................79

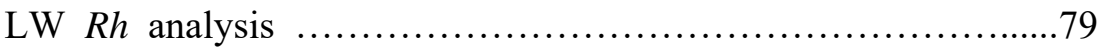

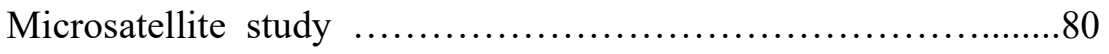

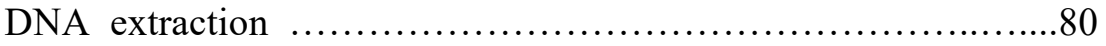

Microsatellite PCR condition and primer setting objectives..........81

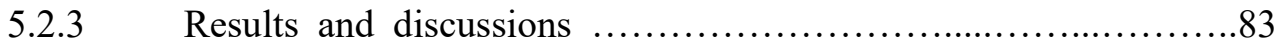

Nuclear DNA study by LW $R h \ldots \ldots \ldots \ldots \ldots \ldots \ldots \ldots \ldots \ldots \ldots . . . \ldots 3$

Presence of heterozygous colony in L34 and L46 ...............85

Microsatellite study $\ldots \ldots \ldots \ldots \ldots \ldots \ldots \ldots \ldots \ldots \ldots \ldots \ldots \ldots . . \ldots 1$

Microsatellite markers failed to detect identical alleles .............88

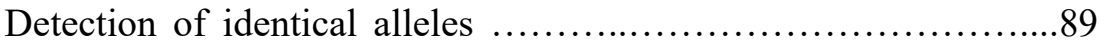

Limitation of the study .......................................92

Chapter 6. General discussion and conclusions ........................................93

6.1 General discussion ...........................................................93

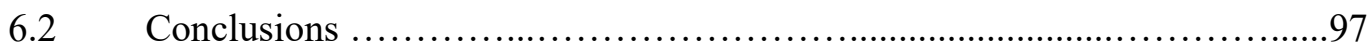

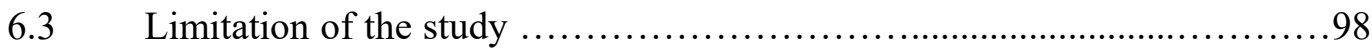

Acknowledgements $\quad$................................................................99

References $\quad$.....................................................................101

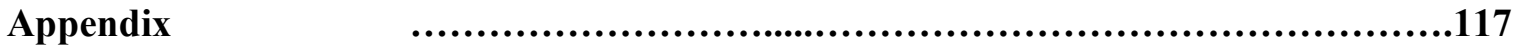




\section{LIST OF FIGURES}

\section{Chapter 1}

Fig. 1.1 Summary of the phylogeographic study of O. smaragdina by Azuma et al. (2006) and Asaka (2010) ...........................................

Fig. 1.2 Phylogeography of population groups of weaver ant, O. smaragdina with reference to geography modified from Azuma et al. (2006) ................5

\section{Chapter 2}

Fig. 2.1 Geochoronologic classification of the fossil species .27

\section{Chapter 3}

Fig. 3.1 Sampling sites of 5 broad areas based on three main rivers in Bangladesh. The red line across the map showing the river flow that separated 5 broad areas in Bangladesh. In the text, red color indicating the district name from

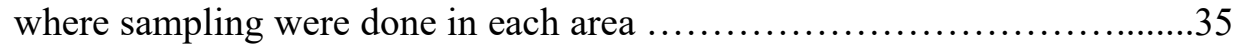

Fig. 3.2 Sampling sites of Oecophylla smaragdina in Bangladesh .................38

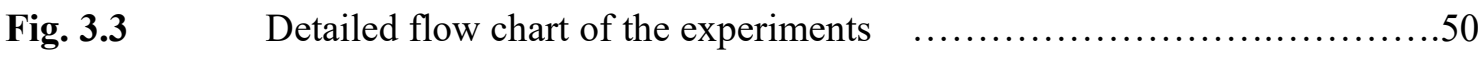

\section{Chapter 4}

Fig. 4.1 Bayesian phylogenetic tree of Bangladeshi O. smaragdina populations as inferred from the mitochondrial gene fragments (1143bp) of the COI (639 
bp) and the Cytb (504 bp) genes (substitution model: GTR + I + G 1000000 generations used in MrBayes 3.1.2 MrModeltest 2.3,PAUP*4.0b10).

Fig. 4.2 Distribution pattern of Indian and SE Asian types of O. smaragdina in Bangladesh ...................................................59

Fig. 4.3 Twenty five haplotypes in Bangladesh and their variable sites with changed position. The upper three numeric lines denotes the position on longitudinal basis of the each sequence. Each dot represent the identical sequence .....63

Fig. 4.4 Haplotype network of O. smaragdina. Solid colored circles indicate individual haplotype. A single bar connecting two haplotypes corresponds to a single base pair mutation. Each hatch mark on the bar indicate single base pair mutations. Haplotypes belonging to Indian clades are separated from the SE Asian clades by one of the largest number of mutational steps (27) inferred in the network. The locality information corresponding to each

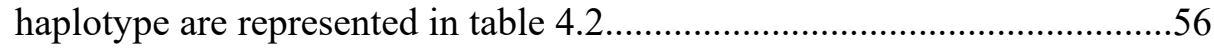

\section{Chapter 5}

Fig. 5.1 Divergence time of Oecophylla smaragdina modified from Azuma et al. (2006). The red text of the area indicating the Indian and SE Asian group of Oecophylla calculated by Azuma et al. 2006 ........................71

Fig. 5.2 Divergence time of Indian and SE Asian types of O. smaragdina in Bangladesh .73

Fig. 5.3 mtDNA and nDNA inconsistency pattern and the heterozygous status within the cell due to crossing of male and female of different Indian and

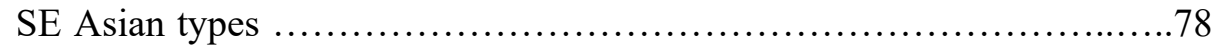


Fig. 5.4 In Bangladesh, O. smaragdina types inferred from nDNA by LW $R h$ compared with the results of the types inferred from mtDNA. L34 and L46 showing the inconsistency in mtDNA and nDNA types................84

Fig. 5.5 The inconsistency of the distribution pattern of Indian and SE Asian type of O. smaragdina in Bangladesh inferred from mitochondrial and nuclear DNA analysis. Distribution pattern inferred by mitochondrial DNA analysis were retrieved from (Rahman et al. 2017b). The locality information is the

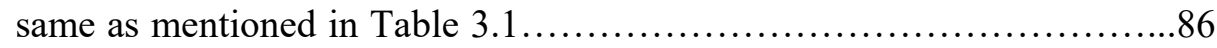

Fig. 5.6 Electropherogrum study to find out the sharing allele position of each individuals per colony $\ldots \ldots \ldots \ldots \ldots \ldots \ldots \ldots \ldots \ldots \ldots \ldots \ldots \ldots \ldots \ldots \ldots$ 


\section{LIST OF TABLES}

\section{Chapter 3}

Table 3.1 Detailed locality information of O. smaragdina sampling sites in

Bangladesh

Table 3.2 Primers for amplifying and sequencing mitochondrial Cytb and CO1and nuclear genes. The positions of primers for mitochondrial genes follow the complete sequence of mitochondrial DNA of Apis mellifera (Crozier and Crozier, 1993) ..............................................44

Table 3.3 The operational status of PCR and cycle sequencing $\ldots \ldots \ldots \ldots \ldots \ldots \ldots \ldots$

\section{Chapter 4}

Table 4.1 Detailed summary of the distribution pattern of weaver ant in Bangladesh ................................................................ 58

Table 4.2 List of haplotypes inferred from COI gene sequences .................. 66

\section{Chapter 5}

Table 5.1 PCR parameters used in microsatellite analysis .81

Table 5.2 List of loci used in microsatellite analysis of $O$. smaragdina in Bangladesh modified from (Azuma et al. 2004) ........................................82

Table 5.3 List of Nuclear DNA haplotypes corresponding to locality .................83

Table 5.4 Allele record for 10 microsatellite loci on 7 localities. $\mathrm{n}$ indicating the number of individuals/ locality 


\section{$\underline{\text { Appendix }}$}

Appendix 1. Detailed locality information with GenBank accession number of sequencing data ................................................117 
CHAPTER 1

GENERAL INTRODUCTION 


\section{CHAPTER 1}

\section{General Introduction}

\subsection{Background of the study}

Phylogeography is comparatively a new discipline that deals with the spatial arrangement of genetic lineages, among and within the closely related species (Avise, 2009). The study of phylogeography combined with classical population analyss deals with historical, phylogenetic components of the spatial distributions of gene lineages, distinguishes between vicariant allopatric divergence, long-distance dispersal or expansion events and investigates the effects of recurrent gene flow in shaping geographical molecular variation (Hewitt, 2004). Mitochondrial DNA (mtDNA) has been widely used in phylogenetic studies, because it evolves rapidly and provides an abundance of genotypic characters, either by restriction fragment analysis or amplification by PCR and subsequent nucleotide sequencing (Randi et al. 2001). The mitochondrial Cytochrome b (Cytb) gene and Cytochrome oxidase subunit I (COI) gene were used in many phylogeographic studies, since this region seems to has a proper substitution rate for analyzing intra species phylogeny of Hymenoptera and some insect-specific oligonucleotide primers are already designed for this gene (Patwardhan et al. 2014). Mitochondrial DNA, in conjunction with morphological data and nuclear-gene (e.g., allozyme) studies, can be a powerful tool for detecting hybridization (Dowling et al. 2015; Dowling and DeMaris, 1993). In addition, comparisons of nDNA and mtDNA suggest that interspecific hybridization has been a persistent feature in the history of this group. 
Oecophylla (Hymenoptera, Formicidae) is the weaver ant and is a broadly distributed genus. Weaver ants constitute the genus Oecophylla (Formicidae, Formicinae) which consists of only three extant species, O. longinoda, O. smaragdina and O. kolhapurensis. Oecophylla. longinoda (Latrelille, 1802) is distributed in tropical and subtropical Africa and $O$. smaragdina (Fabricius, 1775) in southeastern Asia and Australia including many tropical western pacific island (Bolton, 1995). The recently identified species O. kolhapurensis is distributed in western India (Kurane et al. 2015). Oecophylla originated in the early Paleogene of the Palaearctic realm, radiating strongly during the climatic changes of the Eocene-Oligocene transition (Dlussky et al. 2008). Oecophylla smaragdina and O. longinoda were estimated to be diverged at 13.3-11.3 Ma, while the diversification within the groups of O. smaragdina was estimated between 7.8 to $3.6 \mathrm{Ma}$, from the middle Pliocene to early Pleistocene (Azuma et al. 2006). Since O. smaragdina is an arboreal species, inseminated queens lifted by the wind than terrestrial ants. Rafting has been considered effective for between-island dispersal of several species of insects (Thornton, 1996), and weaver ants construct light and waterproof nests of leaves which appear to be a preadaptation for rafting dispersal.

Azuma et al. (2002) first analyzed populations of O. smaragdina using molecular data and samples of $O$. smaragdina from Bangladesh. Including additional populations of $O$. smaragdina from India, Southeast Asia and Australia, Azuma et al. (2006) proposed an outline of the phylogeography of $O$. smaragdina and categorized the sampled populations into 7 major clades: group 1 from India; group 2 from Southeast Asian mainland including the Indochinese and Malayan Peninsula as well as the Greater Sunda Islands; group 3 from the Philippines; group 4 from Flores; group 5 from Sulawesi; group 6 from Halmahera; group 7 from Australia and New Guinea. Hereafter, I call their group 1 as the Indian type and group 
2 as Southeast Asian type. Asaka (2010) extended the survey of O. smaragdina to South Asia, and collected several samples from India and Sri Lanka. Her phylogenetic analysis showed that all analyzed samples belong to Indian type with low levels of sequence divergence (Fig. $1.1)$.

Based on those data, Bangladesh is considered a major transition zone between Indian and Southeast Asian populations as Bangladesh populations of O. smaragdina is identified as SE Asian types. This is the unique case of population boundaries without any distinguished geographical borders (e.g., deep sea or high mountains) although the seven groups of $O$. smaragdina based on haplotype grouping by Azuma et al. (2006) are geographically bordered by the sea, except the group 1 and group 2 (Fig. 1.2). The major rivers are considered as the geographical border between India and Bangladesh, and as all Indian isolates are found to be Indian type (Asaka, 2010; Azuma et al. 2006), Bangladesh is a major focusing area to find out the border between Indian and SE Asian types. As in Bangladesh, 3 main rivers Ganges, Jamuna and Meghna originated during Pleistocene and crisscrossed throughout the mostly flat territories of the country, these rivers might have some influence of separating the Indian type and the SE Asian type in Bangladesh.

\subsection{Problem statement}

Azuma et al. (2006) characterized the mitochondrial sequence identity of the Bangladesh populations as the Southeast Asian clade in spite of geographical proximity of Bangladesh to India. So, there might be some barriers of Indian type to reach into Bangladesh, although no such evidence was found. Moreover, Bangladesh is a plane land area with the 3 big rivers 
Phylogeographic distribution of $O$. smaragdina

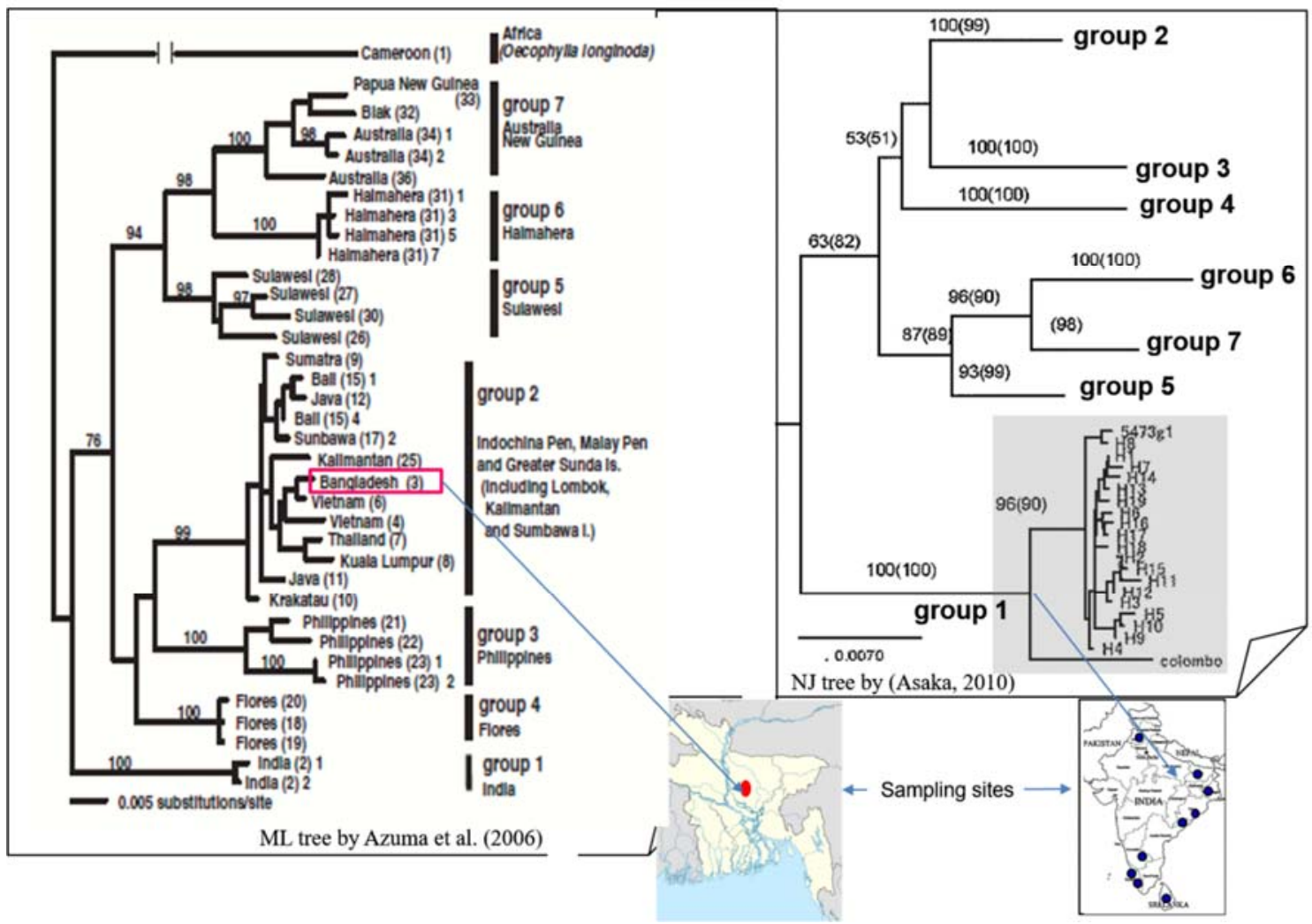

Fig.1.1 Summary of the phylogeographic study of O. smaragdina by Azuma et al. (2006) and Asaka (2010) 


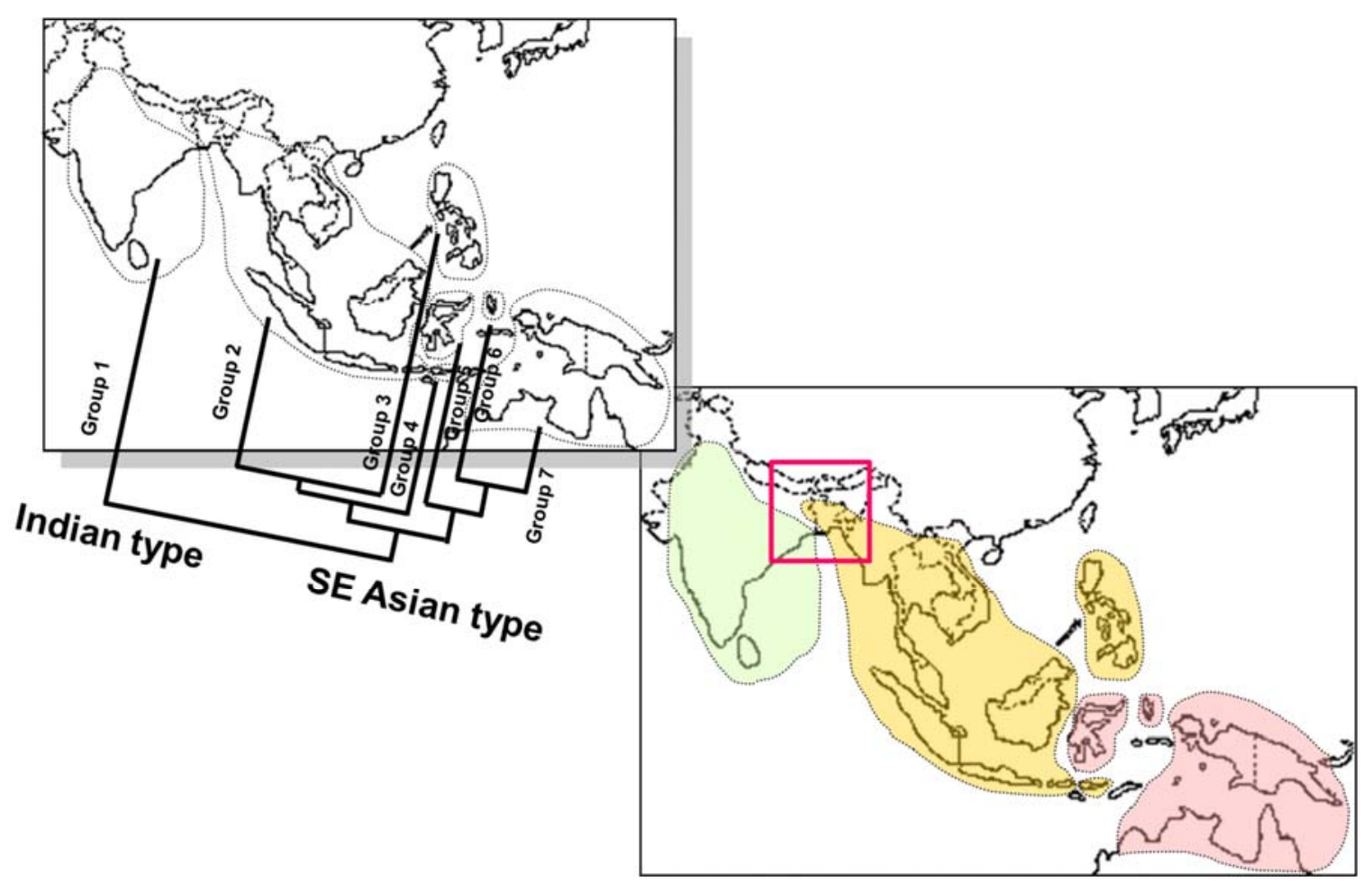

Fig.1.2 Phylogeography of population groups of weaver ant, O. smaragdina with reference to geography modified from Azuma et al. (2006). 
separated the Bangladesh geography from India. The river might be the barrier but no such a study was carried out before. On the contrary, rafting method of dispersal along with the nuptial flight is very common in O. smaragdina. So, barrier effect along with the geological history needs to be considered with a strong evidence which is also lacking. Azuma (2006) analyzed the Bangladesh sample from just one locality i.e., Nurbag. However, for getting the actual phylogeographic history, it is necessary to analyze the samples from different parts of the country more comprehensively. Data on the hybridization scenario of Indian and SE Asian types of $O$. smaragdina in this subcontinent was also lacking. Therefore, with this study, can have a glimpse of the phylogenetic study as well as the hybrid scenario of $O$. smaragdina in Bangladesh.

For checking those 3 rivers, Ganges, Jamuna and Meghna as borders, O. smaragdina was collected from 5 broadly categorized area based on three main rivers for phylogeographic analysis. From the analysis if it is found that all populations belong to Indian type, then it can be said that the previous results of Azuma et al. (2006), who showed that the Oecophylla population from area 3 was SE Asian type, will be exceptional.

For analyzing the existing border, if the collected sample from area 1 and area 2 is found SE Asian type, then it can be stated that the river Ganga will be the possible border for separating the two populations. If area 1 and area 2 denotes Indian Populations but area 3, area 4 and area 5 present the SE Asian type of population, then it can be said that, the river Jamuna is the border. If, area 1, area 2 and area 3 found Indian type but area 4 and area 5 as SE Asian type, then there is the possibility of Meghna river as existing border. If all populations from the 5 area found SE Asian type, then it will be clear that the river Ganga is the border as this river separating this two countries. If all population from the 5 area are found to be Indian type, then it can be said that the border is not existing in Bangladesh. It 
may be the Arakan mountains that separate Bangladesh from Myanmar and also the two populations of Oecophylla as well.

\subsection{Objectives of the study}

The present study aims to show an evolutionary aspect of the distribution of $O$. smaragdina. The first purpose is to test whether all the O. smaragdina populations in Bangladesh belong to SE Asian type or not. If not, the question arises where the boundary of SE Asian type and Indian type is. In other word, the second purpose of the study is to depict the distribution pattern of types at mtDNA level. This could be clarifying the limitation of the SE Asian type distribution in westward. Additionally, the hybridization of SE Asian and Indian types will be verified. Finally the study attempts to propose the probable cause of the revealed distribution pattern of $O$. smaragdina in Bangladesh.

\subsection{Outline of the dissertation}

This doctoral dissertation combines 6 chapters. In Chapter 1, the background, justification, hypothesis and objectives of the research are presented. Chapter 2 included some previous studies and their finding regarding the Phylogeography of O. smaragdina.

Chapter 3 focuses on the general methodology of conducting the several experiment for phylogeographic study. Chapter 4 sheds light on the phylogenetic study, distribution pattern and haplotype network analysis of O. smaragdina in Bangladesh. Chapter $\mathbf{5}$ describes the divergence time and the hybridization scenario of the two types of Oecophylla smaragdina in Bangladesh. Chapter 6 represents general discussion and the comprehensive conclusion of the study. The last parts outline the acknowledgement, references and appendix. 
CHAPTER 2

\section{REVIEW OF THE PREVIOUS STUDY}




\section{CHAPTER 2}

\section{Review of the previous study}

\subsection{Phylogeographic study}

The study of phylogeography combined with classical population genetics deals with historical, phylogenetic components of the spatial distributions of gene lineages, distinguish between vicariant allopatric divergence, long-distance dispersal or expansion events and investigate the effects of recurrent gene flow in shaping geographical molecular variation (Hewitt, 2004).

In molecular phylogeny, the relationships among, usually extant, organisms along with the modified total DNA content due to evolution are examined by comparing homologous DNA or protein sequence. Phylogeography offers the tools to shed light on the evolutionary relationship among different taxa with reference to the structure of population genealogies by demographic history. Moreover, it can also make inferences about temporal changes in the physical and biotic environment of a population using present day genetic data (Beheregaray, 2008).

\subsubsection{Mitochondrial DNA analysis}

Mitochondria, the powerhouse of a cell plays a crucial role in respiration, genetic illness, aging and self-destruction of a cell (Faure and Casanova, 2006). The genetic material in mitochondria, the mitochondrial DNA (mtDNA) contains genes involved in production of enzymes for oxidative phosphorylation and protein synthesis. Mitochondrial DNA (mtDNA) 
has been widely used in phylogenetic studies, because it evolves rapidly and provides an abundance of genotypic characters, either by restriction fragment analysis or amplification by PCR and subsequent nucleotide sequencing (Randi et al. 2001). Mitochondrial genome sequence and structure provide evolutionary and comparative genomics information as well as information on molecular evolution, and patterns of gene flow, phylogenetics and population genetics resources. Like other animals, insect mitochondrial genome is a double stranded molecule consists of 37 genes encoding the large and small subunit ribosomal RNAs, 22 transfer RNAs (trnI, $\operatorname{trn} Q, \operatorname{trn} M, \operatorname{trn} W, \operatorname{trnC}, \operatorname{trn} Y, \operatorname{trnL} 1, \operatorname{trn} K, \operatorname{trn} \mathrm{D}, \operatorname{trn} \mathrm{G}, \operatorname{trn} \mathrm{A}, \operatorname{trn} \mathrm{R}, \operatorname{trn} N$, $\operatorname{trnS} 1, \operatorname{trnE}, \operatorname{trnF}, \operatorname{trnH}, \operatorname{trnT}, \operatorname{trn} P, \operatorname{trnS} 2, \operatorname{trnL} 2, \operatorname{trnV})$ necessary to translate the protein-coding genes and 13 protein coding genes that are all components of the oxidative phosphorylation process (Faure et al. 2011).

In phylogenetic study, mitochondrial DNA has many advantages. They possess strict maternal transmission with high mutation rate due to limited repair system (5-10 times that of nuclear DNA) (Mauro et al. 2006) and conserved simple structure. These unique properties allow the development of universal primers and easy recovery from small or degraded biological sample due to its high copy number in most cells with a different evolution rate in different regions of mitochondrial DNA. This fact facilitates the monitoring of its transmission along the evolutive lines starting in the early evolution. In the case that one individual is not available for a direct comparison with a biological sample, any sample which comes from the maternal genitor can be a good and usable one (Mauro et al. 2006).

The mitochondrial cytochrome b (Cytb) gene and cytochrome oxidase subunit I (COI) gene were used in many phylogeographic studies, since this region seems to have a proper substitution rate for analyzing within-species phylogeny of Hymenoptera and some insectspecific oligonucleotide primers are already designed for this gene (Patwardhan et al. 2014). 
The enzyme cytochrome c oxidase I is a very well known protein of electron transport chain and is found in both bacteria and mitochondria. The COI and COII genes code for two of seven polypeptide subunits in the cytochrome c oxidase complex. The COI gene consists of approximately $894 \mathrm{bp}$. COI and/or COII sequences have been applied to phylogenetic problems at a wide range of hierarchical levels in insects, from closely related species to genera and subfamilies, families, and even orders. The COI gene is slowly evolving compared to other protein coding mitochondrial genes and is widely used for estimating molecular phylogenies and is a good performer in recovering an expected tree (Rawlings et al. 2001). Sequencing both the genes represents one of the largest sequence data sets generated for phylogenetic study of

any group and also fulfils the putative phylogenetic accuracy. COI has recently been suggested as a potential 'barcode' for insect identification in general.

Cytochrome-b gene $(\sim 1,143 \mathrm{bp})$ is reported as the most useful marker in recovering phylogenetic relationships among closely related taxa but it can lose resolution at deeper nodes (Randi et al. 2001). Although the cytochrome-b gene has proven useful in recovering phylogenetically useful information at a variety of taxonomic levels, strength of its utility can be lineage-dependent and declines with evolutionary depth. Study of the haplotype network based on mitochondrial DNA nucleotide sequences and estimation of time of divergence were also very important for accurate tracing of the phylogeographic study of weaver ant population.

\subsubsection{Nuclear DNA for detecting hybridization}

Genetic variation within maternal lineages as reflected by mitochondrial DNA (mtDNA) is commonly used to trace ancient population migrations, demographic history, phylogeography and phylogeny. Since in vertebrates mtDNA population genetic analyses is confined to tracing the migration patterns of maternal lineages, a more complete picture of 
population genetic structure requires analysis of nuclear DNA (nDNA)-encoded markers inherited from both parents. Moreover, being maternally inherited, the mtDNA population diversity reflects maternally directed natal site fidelity, whereas genome-wide bi-parentally inherited nDNA markers assist in quantifying levels of gene flow among subpopulations for both sexes (Bar Yaacov et al. 2012). Ancient hybridization would be most evident in comparisons among phylogenies based on independent character sets, such as mtDNA, allozymes, specific nuclear-gene trees, or morphology (Dowling and DeMaris, 1993). Biogeographical evidence would often support these inferences, for example, changes in distributions associated with Pleistocene glaciation (Dowling and DeMaris, 1993). However, the more likely outcome would be that the bifurcation between the hybridizing species would simply appear more recent than it actually was, because the hybridization would most likely involve sister taxa. Several points need to be considered with regard to hybridization. Hybridization is a problem in phylogenetic analysis only if it goes undetected. If hybridization is apparent, its effects can be taken into account and its occurrence incorporated into the historical narrative of the group as it should be. After all, the purpose of the phylogenetic analysis is to determine the evolutionary history of the group, which may have involved reticulate as well as cladistic events. For detecting the hybridization phenomenon, distribution of mitochondrial haplotypes must be compared with those of nuclear genes as only mt DNA cannot detect (Dowling and DeMaris, 1993). However, the nuclear genes need not be explicitly known Mitochondrial DNA, in conjunction with morphological and nuclear-gene (e.g., allozyme) studies, can be a powerful tool for detecting hybridization (Dowling et al. 2015; Dowling and DeMaris, 1993). More generally, hybridization results in intermediacy of traits determined by nuclear genes and increased variance because the genetic determinants assort independently. The nDNA phylogeny, along with preliminary evidence from amplified fragment length polymorphism data corroborates hypothesis of multiple invasions, providing 
additional details that elucidate the patterns and processes of speciation in Hawaiian Lauapla. In addition, comparisons of nDNA and mtDNA suggest that interspecific hybridization has been a persistent feature in the history of this group.

\subsubsection{Microsatellite study for determining heterozygosity}

Microsatellites, also called short tandem repeats (STRs) or simple sequence repeats (SSRs), are sequential repeats of 1 to 6 base pair motifs that have been used as genetic markers. Microsatellites have been used to measure population differentiation and hybridization (Butler et al. 2014), to investigate ploidy levels and to reconstruct parentage and pedigrees in wild and domestic populations (Steiner et al. 2011). Microsatellites are comparatively cheap to genotype and can be used with low concentrations of DNA. Furthermore, they typically have more alleles per locus than single nucleotide polymorphisms (SNPs) and thus provide more information per locus (Kronauer et al. 2011). In this study, we have conducted microsatellite analysis for determining the heterozygosity and finding the identical alleles. Azuma et al. (2004) characterized the 13 microsatellite loci for the O. smaragdina, which was found to be useful to analyze the genetic structure of Oecophylla species at both the colony and population levels.

\subsubsection{Phylogenetic tree for inferring phylogeography}

Phylogenetic tree is used for representing the phylogeographic relationship of groups of organism. The tree is a simple object consisting of two elements: nodes and branches. Branch is a line that connects two nodes. Bootstrap analyses are performed to test the support for branches of a phylogenetic tree. Mainly four primary methods are used for constructing phylogenetic tree. They are distance method (of which Neighbor-Joining is currently the favored implementation), maximum parsimony (MP), maximum likelihood (ML) and 
Bayesian (BAY) method. Haplotype network is also used to see the correlation pattern raised in phylogenetic tree. This network represents the relationships among the different haploid genotypes observed in the dataset (ie. identical sequences are pooled into a single terminal). They are usually drawn unrooted, which is quite sensible for within-species data, where the root location is often unknown. Bayesian phylogenetic methods were introduced in the 1990s and have since revolutionized the way we analyse genomic sequence data (Ronquist and Huelsenbeck, 2003). Examples of such analyses include phylogeographic analysis of virus spread in humans (Wilfert et al. 2016), inference of phylogeographic history and migration between species, analysis of species diversification rates (Hoorn et al. 2010), divergence time estimation and inference of phylogenetic relationships among species or populations. The popularity of Bayesian methods seems to be due to two factors: (1) the development of powerful models of data analysis; and (2) the availability of user-friendly computer programs to apply the models. In phylogenetics, the tree topology and the substitution model together specify the statistical model for the data. Different tree topologies thus correspond to different models, while the branch lengths or divergence times as well as the substitution parameters (such as the transition/transversion rate ratio) are parameters in the model. The data are usually a molecular sequence alignment or an alignment of morphological characters (or a combination of both). An appealing property of Bayesian inference is that it makes direct probabilistic statements about the model or unknown parameter. 


\subsubsection{Phylogeographic feature in the study at East Asia}

Recently, a great number of phylogeographic studies have been pubslished on insects, plants amphibians, birds, fishes, and several mammals. The result of those study mainly focused on the importance of Pleistocene climate changes and biogeographic barrier such as mountains, rivers, seas and deserts for the diversification, radiation and isolation of the genetic lineage within the species (Riddle et al. 2000). Besides the phylogeographic study (Asaka, 2010; Azuma et al. 2006, 2002) on O. smaragdina, several studies on Asian elephants denoted some phenomenon. Vidya et al. (2009) reported endangered Asian elephant (Elephas maximus), which revealed two highly divergent mitochondrial DNA (mtDNA) lineages, an elucidation of which is central to understanding the species's evolution. They identified several clades based on the divergence history of Asian elephants and suggested a contractionexpansion scenario during severe climatic oscillations of the Quaternary, with range expansions from different refugia during warmer interglacial leading to the varying geographical overlaps of the two mtDNA clades. Brandon-jones (1996) reported similar trends of declining the Oecophylla populations and other mammals after Pleistocene glaciation. Their study also discussed the possibility of variation of the Oecophylla types between Indian and Bangladesh. He described the divergence pattern between the Indian and Bangladeshi types might be due to a combination of submergence of lowlands or islands, deforestation caused by cold and drought in inland Asia, and other environ-mental changes. 


\subsection{Taxonomy, distribution and divergence history of Oecophylla}

\subsubsection{Taxonomy of $O$. smaragdina}

The genus Oecophylla was established by F. Smith in 1860 including two species, Formica smaragdina Fabricius and Formica virescens Fabricius. Subsequently Bingham (1903) designated Oecophylla virescens as type species. The genus is distinct in having triangular mandibles with long apical tooth, palp formula of 5 maxillary and 4 labial, elongate petiole with a low node as well as aggressive behavior and arboreal nesting habit. The latest phylogenetic study (Blaimer et al. 2015) showed that Oecophylla is the sister group of Gesomyrmex, and that the two genera were diverged in 70 to 75 Ma. Presently, 3 names of species are recognized as valid.

(1) Oecophylla smaragdina (Fabricius, 1775)

Formica smaragdina Fabricius, 1775: 828. Type locality: India

Combination in Oecophylla: Smith 1860: 102

Formica virescens Fabricius, 1775: 392. Type locality: Australia

Combination in Oecophylla virescens: Smith, 1860: 102.

As subspecies of Oecophylla smaragdina: Emery, 1887: 242; Forel, 1915: 95; Wheeler, 1922: 228, Emery, 1926: 52.

Junior synonym of Oecophylla smaragdina: Mayr, 1872: 143, Taylor \& Brown, 1985: 127.

Formica viridis Kirby, 1819: 478. Type locality: Australia

Junior synonym of Oecophylla virescens: Roger, 1863:10; Dalla Torre, 1893: 177; Emery, 1925: 52; of Formica smaragdina: Smith, 1857: 53; of Oecophylla smaragdina: Taylor \& Brown, 1985: 127.

Formica macra Guérin-Méneville, 1831: pl. 8, fig.1. Type locality: Indonesia 
Junior synonym of Oechopylla virescens: Smith 1858:29; of Oecophylla smaragdina:

Roger, 1863:10; Dalla Torre, 1893: 176; Arnold, 1922: 609.

Formica zonata Guérin-Méneville, 1838: 295. Type locality: "Port Praslin”, Australia.

Junior synonym of Oechopylla smaragdina: Roger, 1863:10; Dalla Torre, 1893: 176.

(2) Oecophylla longinoda (Latreille, 1802)

Formica longinoda Latreille, 1802: 184. Type locality: Senegal

Combination in Oecophylla: Mayr, 1863: 439.

Junior synonym of Oecophylla virescens: Smith, 1858: 29.

Subspecies of Oecophylla smaragdina: Emery, 1892: 564; Forel, 1907: 15; Santschi, 1914:

128; Santschi, 1919: 345; Emery, 1925: 52; Prins, 1965: 77.

Status as species: Dalla Torre, 1893: 176; Emery, 1921: 102; Wheeler, 1922: 227; Santschi, 1928: 211; Bolton, 1995: 298.

Oecophylla brevinodis André, 1890: 313. Type locality: Sierra Leone.

Subspecies of Oecophylla longinoda: Dalla Torre, 1893: 176; of Oecophylla smaragdina:

Stitz, 1916: 396.

Junior synonym of Oecophylla longinoda: Wheeler, 1922: 945.

\section{(3) Oecophylla kolhapurensis Kurane, Bhoje \& Sathe, 2015}

Oecophylla kolhapurensis Kurane, Bhoje \& Sathe, 2015: 39. Type locality: Kolhapur, Maharashtra, India.

The Asian weaver ant has been represented by a single species, Oecophylla smaragdina, in spite of variations of body color and size. The African weaver ant, Oecophylla longinoda, is 
similar to O. smaragdina. Indeed, it was treated as subspecies of O. smaragdina by some authors at one time.

According to Wheeler (1922), O. smaragdina is distinguished from O. longinoda by the shape of the petiole as follows:

1) In O. smaragdina, the petiole is very slender; its stigmata is very prominent in dorsal view; its ventral surface is nearly straight or very feebly convex in profile

2) In O. longinoda, the petiole is stouter and higher; its stigmata is not prominent in dorsal view; its ventral surface is strongly convex in profile.

The third species, O. kolhapurensis, was recently described from India, but the diagnose showed by Kurane et al. (2015) were obscure and the status as species is doubtful. Indeed, an opinion in "AntWiki*" mentioned that the species is "undoubtedly a junior synonym of common and widespread Oecophylla smaragdina." Although, the statement does not have value as a taxonomic treatment, the species is not taken in consideration here.

The species of the genus exhibits a high degree of variation in worker body color. For example, the workers are light to dark brown in Southeast Asia, but in Australia they are known as "green tree ants" due to the intense green color of the abdomen. Thus there has been a long history of descriptions of infraspecific forms.

Presently 12 valid subspecies names has been recognized:

Subspecies of Oecophylla smaragdina

nominal plus

Oecophylla smaragdina fuscoides Karawaiev, 1933. Type Locality: Indonesia (Java).

Oecophylla smaragdina gracilior Forel, 1911. Type Locality: Indonesia (Java). 
Oecophylla smaragdina gracillima Emery, 1893. Type Locality: Indonesia (Batjan I.).

Oecophylla smaragdina selebensis Emery, 1893. Type Locality: Indonesia (Sulawesi).

Oecophylla smaragdina subnitida Emery, 1892. Type Locality: New Guinea.

Subspecies of Oecopylla longinoda

nominal plus

Oecophylla longinoda annectens Wheeler, 1922. Type Locality: Democratic Republic of Congo.

Oecophylla longinoda claridens Santschi, 1928. Type Locality: Ivory Coast.

Oecophylla longinoda fusca Emery, 1899. Type Locality: Cameroun.

Oecophylla longinoda rubriceps, Wheeler, 1922. Type Locality: Democratic Republic of Congo.

Oecophylla longinoda rufescens, Santschi, 1928. Type Locality: Congo.

Oecophylla longinoda taeniata, Santschi, 1928. Type Locality: Democratic Republic of Congo.

Oecophylla longinoda textor, Wheeler, 1922. Type Locality: Democratic Republic of Congo.

In the case of Oecophylla, the infraspecific names were described in 1890s to 1930s. The concept of subspecies at that time is quite different from modern usage (Brown, 1955). Wheeler (1922) compiled these taxa to the date and showed the distinction in key as below.

1. Petiole very slender, its stigmata seen from above very prominent, its ventral surface nearly straight or very feebly convex in profile (smaragdina) - . . . . . - . - 2

- Petiole stouter and higher, its stigmata seen from above not prominent, its ventral surface strongly convex in profile (longinoda) - - - - - - - - - - - 7

2. Body ferruginous or testaceous - - - - - - - - - - - - - 3

- Gaster and sometimes the head pea-green, head more rouinded and less truncated 
behind; size smaller, petiole somewhat shorter (Queensland, New Guinea, the Islands Aru and Key) - - - - - - - - - subspecies virescens (Fab.)

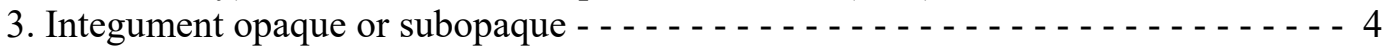

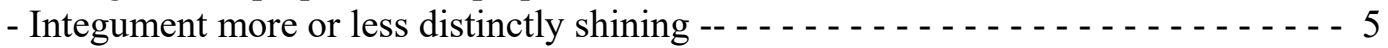

4. Color ferruginotis (India, Ceylon, Cochin China, Indonesia) - $\ldots$ - - - smaragdina (typical)

- Smaller and more testaceous, mesonotum and petiole alittle narrower (Java) - - - - - - - - - -- var. gracilior Forel

5. Large forms, integument slightly shining (Papua, Philippines, Melanesia) - - - - subspecies subnitida Emery

- Smaller forms, integument more shining - - - - - - - - - - - - - - - - - 6

6. Body very shining and slender, color testaceous, head rather elongate - - - - - - - var. gracillima Emery

- Less shining and less slender, head shorter (Celebes) - - - - - - var. selebensis Emery

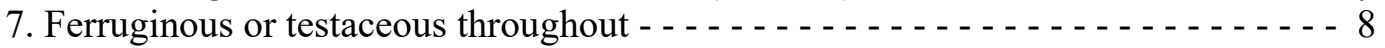

- Brown or black - - - _ - _ - _ -

8. Color ferruginous (West Africa) - - - - - - - - - - - - - longinoda (typical)

- Color paler, more testaceous, petiole shorter, head slightly broader, apical tooth of mandibles shorter (Zanzibar) - - - - - - - - - - - - - - - - var. textor (Santschi)

9. At least the thorax and mandibles black -

- Body rather uniformly brown (Belgian Congo) - - - - - . - - - - - - var. annectens Wheeler

10. Head dull red, gaster often brownish (Belgian Congo) - - - - - - var. rubriceps (Forel)

- Head and gaster black or dark brown (Belgian Congo, Nigeria, Liberia, Cameroon,

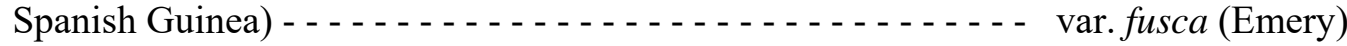

Since then, 4 names were added by Santschi (1928) and Karawaiew (1933) in Oecophylla smaragdina. In term of zoological nomenclature these are valid because no one synonymized then. But it is seldom to refer subspecies categories.

Subspecies refers to geographical populations that have some morphological features distinguishing from other populations. Before the biological species concept was established by Mayr (1942), the terms concerning infraspecies (subspecies, varieties, forma, etc.) were confused. Although ICZN describes the rule of trinomen where only the subspecies is a rank below species, Wilson and Brown (1953) argued that subspecies is not a "real taxa", because of the absence of criteria and thus arbitrariness (see also Mallet, 2007). In ant taxonomy, since both Wilson and Brown were researchers of ants, the application of subspecies were not popular until today. 
If the population is defined by genetic basis and it links with morphological characters, the naming of population or subspecies name might be important to evolutionary work. Phylogeography treats with populations, but in the case of Oecophylla smaragdina, the relationship between the named subspecies and populations treated in phylogeographic studies remains ambiguous. The classification of subspecies is not consistent with grouping based on mtDNA (Azuma et al. 2002, 2008).

\subsubsection{Biology of $O$. smaragdina}

Oecophylla colonies are arboreal, large and polydomous in nature. Workers show the polymorphic characters with diversified organizing behavior in the colony. They are aggressive in nature and well known for their predatory characters. They are able to protect a variety of terrestrial plants against insect pests. Weaver ants formed their nest in the tree canopy by their unique nest building behavior. Workers construct pendulous bag-like nests from cluster of green leaves which are bound together with silk produced by their mature larvae. (Chapuisat and Keller, 2002). Their prominent leaf nests glued ("woven") together with silk from the larvae, can readily be seen on many trees in open and closed forests, and their large colony sizes, often over 500,000 workers, (Lokkers, 1990), is considered as one of the background of dominating behavior.

Oecophylla smaragdina colony starts the life cycle with a mated queen and laying a batch of about 35 eggs within 5 - 10 days after dealation / shedding her wings (Lokkers, 1990). The development of brood depends on temperature however the optimum temperature is $30^{\circ} \mathrm{C}$. Emerging of larvae occurred about day eight. Pupae follow after day 17 and the first adult worker appeared after 28 days (Lokkers, 1990). Those colonies surviving the founding stage will develop into colonies consisting of at least half a million individuals occupying several 
good sized trees (Hölldobler and Wilson, 1990). When the queen dies the workers activate their ovaries and produce a last set of male brood before the colony shrinks as worker numbers reduce over the following months (Lokkers, 1990). The colony can live about 8 years.

Schlüns et al. (2009) reported that $O$. smaragdina promises to be a very interesting study organism because its genetic colony structure deviates from the archetypical case and varies among populations. This is a rare case where colony relatedness is reduced by both polygyny and polyandry at levels specific to each population. Oecophylla smaragdina involves the manner in which nest mates of multiple castes (including larvae) cooperate to construct arboreal silk nests. For crossing gaps, workers form living chains and bring leaves together. The rest of the workers by the help of mandibles hold final instar larvae for using the silk produced by the larvae at the binding position of the leaves, to fasten together leaves to form the nest walls (Hölldobler and Wilson, 1977). This is considered as one of the key factors of achieving such a big colony and dominating behavior in the ecosystem (Schlüns et al. 2009).

\subsubsection{Distribution of $O$. smaragdina and the factors affecting such distribution}

Oecophylla smaragdina is distributed from Australia to tropical and subtropical Asia, India and many tropical islands. Oecophylla longinoda is distributed mainly in tropical and subtropical Africa (Lokkers, 1986; Wheeler, 1922). Among all ant species, O. smaragdina is the most widespread over ocean islands. Behavioral characters of this species along with the environmental effect played the major roles of such distribution. The dispersal of $O$. smaragdina without human intervention indicates that the species has the ability to disperse across wide water barriers. In O. smaragdina, the mating swarming has not been observed and 
described, but only assumed when fertilized queens are found in large quantities in the vegetation. Lokkers, (1990) stated that sexuals 'take part in aerial swarm mating in north Queensland, but he had 'never witnessed the release of queens from a nest. Therefore, he suggested that swarming probably occurs under the cover of darkness. With discriminant analyses, Lokkers, (1986) observed the distribution pattern and suggested that both rainfall and temperature have the marked effect for the distribution of Oecophylla, as low temperatures directly inhibit larval development, and both rainfall and temperature levels limit the distribution of the forest-woodland vegetation required by this arboreal ant. Thus, the climatic condition also has the marked impact on the swarming behavior often leading to change in distribution pattern. Wetterer, (2017) and Peel et al. (2007) reported that the climatic condition of this continent has marked influence of some diverged distribution of Oecophylla and also explained the delimiting weather factors for Oecophylla distribution. According to them, the climatic conditions was much variable in this part might cause the behavioral changes in swarming and mating of weaver ant. Wetterer, (2017) based on the history of distribution and climatic condition with a Köppen-Geiger climate map resulted that the vast majority of $O$. smaragdina having tropical climates with tropical rainforest, monsoon climate. In arid climatic condition, fewer number of O. smaragdina distribution were observed. However, most of them comes from semi arid areas and majority from India or Australis. The moderate range of distributions were recorded in the sub tropical climate with dry winter and rainy summer. 


\subsubsection{Divergence time of $O$. smaragdina}

\section{Paleontological Information}

\section{1) Fossil species}

In spite of only 2 extant species, Oecophylla has many described fossil species. Although some were described based on forewings only from imprints, 16 valid species are recognized (Bolton, 2018). The species list of fossils, as shown below, is broadly based on the data from "Antcat.org", a database of ant taxonomy and from "Fossilworks", a web-based portal to the Paleobiolgy Database.

(1) Oecophylla atavina Cockerell

Oecophylla atavina Cockerell, 1915: 485, pl.64, fig. 7 (m) Bembridge Marls, UK (Eocene) [Age range: 37.2 to $33.9 \mathrm{Ma}$.

Oecophylla perdita Cockerell 1915: 485, pl. 64, figs. 5, 6 (q.m.)

Junior synonym of O. atavina: Dlussky and Perfilieva 2014: 424.

(2) Oecophylla bartoniana Cockerell

Oecophylla bartoniana Cockerell, 1920: 277, pl. 16, fig. 4 (wing) Bagshot Beds, Bournemouth, UK (Eocene) [Age range: 48.6 to $40.4 \mathrm{Ma}$ ]

(3) Oecophylla brischkei Mayr

Oecophylla brischkei Mayr, 1868: 31, pl. 1, figs. 12, 13 (w) Baltic amber, Poland, (Eocene). [Age range: 37.2 to $33.9 \mathrm{Ma}$ ]

[also Wheeler, 1915]

(4) Oecophylla crassinoda Wheeler

Oecophylla crassinoda Wheeler, 1922: 27. Baltic amber (Eocene)

Replacement name for Oecophylla brevinodis Wheeler, 1915: 116

[Junior primary homonym of Oecophylla brevinodis André, 1890: 313.]

(5) Oecophylla eckfeldiana Dlussky, Wappler and Wedmann 
Oecophylla eckfeldiana Dlussky, Wappler and Wedmann, 2008: 619, fig. 4 (w.q.). Eckfeild Maar, Germany (Eocene) [Age range: 48.6 to $40.4 \mathrm{Ma}$ ]

(6) Oecophylla grandimandibula Riou

Oecophylla grandimandibula Riou, 1999: 130 (alate, sex not indicated) Ardèche, France (Miocene) [Age range: 8.7 to $5.3 \mathrm{Ma}$ ]

(7) Oecophylla kraussei (Dlussky and Rasnitsyn)

Camponotites kraussei Dlussky and Rasnitsyn, 1999:74, fig 2 (q.) U.S.A. (Early Eocene). [Age range: 55.8 to $48.6 \mathrm{Ma}$ ]

Combination in Oecophylla: Perfilieva,Dubovikoff and Dlussky, 2017: 399.

See also Dlussky \& Rasnitsyn, 2003: 418; Dlussky, Karl, Brauckmann, Gröning and Reich, 2011:452; Archibald, S. B., Rasnitsyn, A. P., Brothers, D. J.; Mathewes, R. W. 2018: fig. $12 \mathrm{G}$

(8) Oecophylla leakeyi Wilson and Taylor

Oecophylla leakeyi Wilson and Taylor, 1964: 93, fig. 2, pl. 2 (w.1.). Mfwangano Island, Kenya (Miocene) [Age range: 20.43 to $15.97 \mathrm{Ma}$ ]

(9) Oecophylla longiceps Dlussky, Wappler and Wedmann

Oecophylla longiceps Dlussky, Wappler and Wedmann, 2008: 617, figs. 2, 3 6A (q.m.) Hessen, Germany (Eocene). [Age range: 48.6 to $40.4 \mathrm{Ma}$ ]

(10) Oecophylla macroptera (Dlussky)

Camponotites macroptera Dlussky, 1981: 76, fig. 53 (q.). RUSSIA (Middle Miocene). Combination in Oecophylla: Perfilieva,Dubovikoff and Dlussky, 2017: 399.

(11) Oecophylla megarche Cockerell

Oecophylla megarche Cockerell, 1915: 486, pl.65, fig. 1-3 (q.) Bembridge Marls, UK (Eocene). [Age range: 37.2 to 33.9 Ma] [See also Dlussky and Perfilieva, 2014:426] (12) Oecophylla obesa (Heer) 
Formica obesa Heer, 1849: 108, pl. 8, fig. 1 (q.) Radoboj, Croatia (Miocene) [Age range: 37.2 to $11.608 \mathrm{Ma}]$

Combination in Oecophylla: Mayr, 1867b: 50; Dlussky \& Putyatina, 2014: 252, figs. 5AF, 18A-B, 18E (q.m.).

Attopsis longipes Heer, 1867: 29, pl. 2, fig. 15 (m.?) Croatia (Miocene).

See also Förster, 1891: 442.

Junior synonym of Oecophylla obesa: Dlussky \& Putyatina, 2014: 252.

Formica pinguis Heer, 1849: 110, pl. 8, figs. 3, 4 (q.) Croatia (Miocene).

Combination in Camponotus: Mayr, 1867b: 51. Junior synonym of Oecophylla obesa: Dlussky \& Putyatina, 2014: 252.

Attopsis anthracina Heer, 1849: 156, pl. 12, fig. 12 (m.) Croatia.

Combination in Cataulacus: Mayr, 1867b: 58.

Senior synonym of Cataulacus nigra: Mayr, 1867b: 58.

See also: Bolton, 1974a: 87.

Junior synonym of Oecophylla obesa: Dlussky \& Putyatina, 2014: 252.

Attopsis nigra Heer, 1849: 157, pl. 12, fig. 13 (q.) Croatia.

Combination in Cataulacus: Mayr, 1867b: 58.

Junior synonym of Cataulacus anthracinus: Mayr, 1867b: 58.

(13) Oecophylla praeclara Förster

Oecophylla praeclara Förster, 1891: 432, pl. 13, fig. 6 (q.) Brunstatt, France (Oligocene).

[Age range: 33.9 to $28.4 \mathrm{Ma}$ ]

(14) Oecophylla sicula Emery, 1891

Oecophylla sicula Emery, 1891b: 156, pl. 3, figs. 36, 37 (w.) Sicilian amber, Italy (Tertiary). [Age range: 11.608 to $5.332 \mathrm{Ma}$ ] [also Brown \& Wilson, 1978]

(15) Oecophylla superba Théobald, 1937 
Oecophylla superba Théobald, 1937a: 212, pl. 4, fig. 17; pl. 15, fig. 1 (q.) Kleinkembs, Germany (Eocene/Oligocene Boundary). [Age range: 33.9 to $28.4 \mathrm{Ma}$

(16) Oecophylla taurica Perfilieva, Dubovikoff \& Dlussky, 2017

Oecophylla taurica Perfilieva, Dubovikoff \& Dlussky, 2017: 399, fig. 7, pl. 7.6 (q.) Malyi Kamyshlak, Crimean Peninsula, Russia (Middle Miocene).

In addition,Viehmeyer (1913) reported O. smaragdina selebensis found at Celebes copal (Quaternary of Indonesia). Zhang (1989: 297) transfered Rabidia xiejiaheensis Hong from Miocene under genus Oecophylla. Later the species was treated under Camponotites by Dlussky et al. (2008: 616). Bolton (2018) considered both Oecophylla xiejiaheensis and Rabidia xiejiaheensis as unavailable and uncategorized.

There was a confusion in the genus Camponotites. Dlussky established monotypic extinct genus Camponotites in 1981, based on the Camponotites macropterus from Russia, which is a forewing impression fossil. But this name is a junior homonym of Camponotites Steibach, 1967. The taxon was treated as incertae sedis in Formicidae by Hölldobler \& Wilson (1990: 18) and Dlussky \& Rasnitsyn (2002: 418), or in Formicinae by Bolton (1994: 50), Bolton (1995b: 83) and Bolton (2003: 112). Dlussky et al. (2011) treated Camponotites Dlussky as junior homonym and junior synonym of Campnotites Steinbach. The latest taxonomic treatment of the taxon is that of Perfilieva et al. (2017) in text where the genus Camponotites is a junior synonym of Oechophylla by implication as type-species of Camponotites Dlussky transferred to Oecophylla, but not not fully accepted (Bolton, 2018) 


\section{2) Geochronology and distribution of fossil species.}

\begin{tabular}{|c|c|c|c|}
\hline Era & Period & Epoch & Holocene \\
\hline \multirow{8}{*}{ Cenozoic } & Quaternary & Pleistocene & $0.01(\mathrm{Ma})$ \\
\hline & \multirow[b]{2}{*}{ Neogene } & Pliocene & \multirow{2}{*}{$\begin{array}{l}2.59 \\
5.33\end{array}$} \\
\hline & & Miocene & \\
\hline & \multirow{5}{*}{ Paleogene } & & \multirow{4}{*}{33.9} \\
\hline & & Oligocene & \\
\hline & & & \\
\hline & & Eocene & \\
\hline & & Paleocene & \multirow{2}{*}{$\begin{array}{l}55.8 \\
65.5\end{array}$} \\
\hline Mesozoic & Cretaceous & & \\
\hline
\end{tabular}

Fig. 2.1 Geochronologic classification of the fossil species

The fossil species are predominantly found from middle Eocene to Miocene in Europe (Fig. 2.1). Apart from O. kraussei from Klondike Mountain Formation, Washington State, USA in Early Eocine, the early fossils of the genus were described based on the materials from Europe. Two species are described from the Middle Eocene, O. longiceps and O. eckfeldiana both from Germany. In the Upper Eocene, six species are described: O. brischkei, O. crassinoda from Baltic amber; O. praeclara from Germany, O. bartoniana, O. atavina, and O. megarche from UK. In the Oligocene, two species are described; O. superba from Kleinkembs, France and O. sicula from Sicilian amber. In the Miocene, O. obesa from Croatia, O. leakeyi from Kenya and O. taurica from Russia.

The age of the Oecophylla is back to $48.6 \mathrm{Ma}$ and the distribution is summarized as follows (Fossilwork):

Quaternary: Indonesia (Viehmeyer, 1912)

Miocene: Croatia (Uger, 1841, Heer, 1849, 1865), France (Weidner and Riou, 1986), Germany (Heer, 1847, 1849), Italy (Brown \& Carpenter, 1978), and Kenya (Wilson \& Taylor, 1964) 
Oligocene: France (Förster, 1891) and Germany (Theobald, 1937)

Eocene: the Czech Republic (Deichmüller, 1881), Germany (Dlussky et al, 2009), Poland (Holl, 1829, Menge, 1854), Russia (Mayr, 1868, Cockerell, 1909, Enderlein, 1910, Ulmer, 1912), and UK (Cockerell, 1915)

Azuma et al. (2006) estimated the divergence time of Oecophylla smaragdina. Based on that estimation, O. smaragdina and O. longinoda diverged 13.3- 11.3 Ma, in the late Miocene. Diversification within the seven groups have been estimated between 7.8 and 3.6 Ma. Most likely Oecophylla originated in the early Paleogene in the Palaearctic realm, radiating strongly during the climatic changes of the Eocene-Oligocene transition (Dlussky et al. 2008). According to the fossil records, Oecophylla might have originated in the early Paleogene (ca. $60 \mathrm{Ma})$ in the Palaearctic region, and dispersed during the climatic changes of the EoceneOligocene transition at ca. 43 Ma (Dlussky et al. 2008). Recently, Blaimer et al. (2015) estimated the divergence time of the genus Oecophylla based on the fossil records and ultra conserved elements (UCEs). They estimated that Oecophylla crown group evolved during Oligocene at ca. $<30 \mathrm{Ma}$ and stem-group evolved during early Eocene at ca.50 Ma. The divergence time of Oecophylla are shown here based on (Azuma et al. 2006; Dlussky et al. 2008) resulted that diversification within the groups of $O$. smaragdina occurred between 4.7 Ma to 0.7 Ma ago. 


\subsection{Geology of Bangladesh and its importance for phylogeographic study of weaver ant}

Bangladesh is a riverine country with three main rivers Ganga, Jamuna and Meghna crisscrossed throughout the mostly flat territories of the country. Bangladesh is surrounded in the north, west and south by India, by Myanmar in the Southeast and by Bay of Bengal in the south. The river Ganges (Known all over the Bangladesh as Padma) is a trans-boundary river acting as a barrier of India and Bangladesh. The river rises in the western Himalayas in the Indian state of Uttarakhand, and flows south and east through the Gangetic Plain of North India into Bangladesh, where it empties into the Bay of Bengal. Bangladesh's geology began 350 million years ago when the Pangean supercontinent broke apart (Mannan, 2002). The Bengal Basin began 127 million years ago when the Indian Plate rifted away from Antartica at $18 \mathrm{~cm}$ per year for 20 million years.

This rapid velocity stopped 55 million years ago and was followed by a period in which little or no spreading took place west of the Ninety East Ridge for 20 million years. The Indian subcontinent lies atop the Indian tectonic plate, a minor plate within the Indo-Australian Plate (Gibbons et al. 2012). Its defining geological processes began a north eastwards drift lasting fifty million years across the then unformed Indian Ocean. The subcontinent's subsequent collision with the Eurasian Plate and subduction under it, gave rise to the Himalayas, the planet's highest mountains (Ali, 2005; Gibbons et al. 2012). In the former seabed immediately south of the emerging Himalayas, plate movement created a vast trough, which, having gradually been filled with sediment borne by the Indus and its tributaries and the Ganges and its tributaries, now forms the Indo-Gangetic Plain (Uddin and Lundberg, 1999). The second largest river Jamuna is derived from the Himalayas as Brahmaputra river. The river drains the 
Himalaya east of the Indo-Nepal border, southern-central portion of the Tibetan plateau above the Ganges basin and adjoint with Ganga, near chandpur and fall into Bay of Bengal. The river mainly formed during the period Holocene (Pickering et al. 2014). The Meghna is a distributary of the Brahmaputra. The Meghna is formed inside Bangladesh by the joining of the Surma and Kushiyara rivers originating from the hilly regions of eastern India. Down to Chandpur, Meghna is hydrographically referred to as the Upper Meghna. This rivers forms the Bengal basin at around 5-10 milliion years ago (Uddin and Lundberg, 1999). So, all the main rivers originating from different period of time, separating the countries with some definite geological areas. The southeast border of Bangladesh is separated by the mountain Arakans from Myanmar. Arakan Mountains formed by the compression as Indian plate collided with the Eurasian plate approximately along the boundary between India and Myanmar at around 71 ma ago. This mountain are submerged in Bay of Bengal for sufficiently long stretch and emerges against in the form of Andaman and Nicobar Island and the highest peak was found about $3055 \mathrm{~m}$ (Aitchison et al. 2008).

Formation of the Bengal basin in led to development of Bangladesh is corresponded to the divergence of $O$. smaragdina. Bengal delta being prograding in nature since its inception covers entire Bengal basin. The prograding nature of the delta has been intervened with sea transgression number of times in its geologic history. With, a low-lying delta complex associated with the Ganges, Brahmaputra-Jamuna, Meghna rivers form one of the largest depositional systems in the World (Goodbred and Kuehl, 2000). The major rivers, viz., the Ganges, the Brahmaputra-Jamuna, the Meghna and their tributaries and distributaries have been acting as the primary transporting media of the sediments in the delta building and subsequently emerged as the Bengal delta. In view of the contribution in the delta building by the rivers Ganges, Brahmaputra-Jamuna, Meghna and their tributaries and distributaries, the 
delta may be termed as Ganges Brahmaputra- Meghna (GBM) delta. Similarly inbred tectonism of the Indian plate has been playing a significant role in the development of the GBM delta (Chowdhury, 2012). The vital tectonic element, viz., Himalayas in the north and Indo-Burma range in the east, have been acting virtually as in exhausting sources of sediments. The river Ganges and Brahmaputra drain the NW and NE portion of the Himalayas to the Bay of Bengal over the delta. Subduction tectonics of the Indo-Burma convergent system and differential subsidence and up liftment largely controlled the basin architecture. Mannan (2002) studied on the Surma basin in Bangladesh, and according to him, most of the country is covered by thick layers of sediments. The country occupies most of the Bengal basin eroded from the eastern Himalayas and the Indo-Burman Ranges, and carried by major river systems similar to the present-day Ganges and Brahmaputra. The basin is bordered by the Indian plate to the west; the Himalaya to the north; the Shillong plateau, India, to the northeast; the Indo-Burman Ranges to the east; and the Bay of Bengal to the south. Sedimentation in the basin has been almost continuous for 65.5 million years. The first clearly orogenic detritus is in the lowermost 23 million year old strata. The Surma Basin is a sub-basin of the Bengal Basin, which was formed about 127 million years ago when the Indian plate rifted away from Antarctica. . onshore part of the Bengal Basin is the site of the world's largest formed by rivers (Ganges, Brahmaputra/Jamuna, Padma, Meghna) that drain a large portion of the Himalayas. Formation of the basin and its subsequent development might have some impact for the development of vegetation and other ecological niche as suitable host for Oecophylla. As the Bengal basin formation has a long history influenced by the origination and flow channel of the riverine border, so this could be the key issue for further phylogenetic study. In all the cases of such basin formation, climate change has the marked impact specially in the last glacial maximum (LGM). During LGM, most of the river system in Bangladesh was largely inactive in terms of sediment deposition but after glaciation the magnitude of sediment discharge increased 
substantially which facilitate the formation of different basins and also facilitate the formation of vegetation of the concrete locality (Goodbred, 2003).

\subsection{Phylogenetic study of $O$. smaragdina in Asian continents}

Weaver ant has an evolutionary importance which is corresponding to geography and geological history of the earth. Azuma et al. (2002) first analyzed populations of $O$. smaragdina including samples from Bangladesh. She also added comprehensive samples of $O$. smaragdina from India, Southeast Asia and Australia using molecular data, Azuma et al. (2006) proposed an outline of the phylogeography of $O$. smaragdina and categorized the sampled populations into 7 major clades: group 1 from India; group 2 from Southeast Asian mainland including the Indochinese and Malayan Peninsulas, as well as the Greater Sunda Islands; group 3 from the Philippines; group 4 from Flores; group 5 from

Sulawesi; group 6 from Halmahera; group 7 from Australia and New Guinea. Asaka, (2010) extended the survey of O. smaragdina to South Asia and collected several samples from India and Sri Lanka. Her phylogenetic analysis showed that all analyzed samples belong to Indian clade with low levels of sequence divergence. Azuma et al. (2006) characterized the mitochondrial sequence identity of the Bangladesh populations as Southeast Asian clade in spite of the geographical proximity of Bangladesh to India. 


\section{CHAPTER 3}

\section{GENERAL METHODOLOGY}




\section{CHAPTER 3}

\section{General Methodology}

\subsection{Sampling of Oecophylla smaragdina in Bangladesh}

\section{The setting of the study sites}

Based on three main rivers, Ganges, Jamuna, and Meghna, the study area in Bangladesh was broadly categorized into five areas under 8 division. The detailed information of that 5 broad areas is presented in the following figure (Fig. 3.1).

Area 01 included the northwestern part of Bangladesh. This area include 16 districts under 2 divisions. The climate of this area is comparatively dry with very hot summer and cold winter to other areas. This area is surrounded by the river Ganges and Jamuna. The study area lies between $24^{\circ} 07^{\prime} \mathrm{N}$ to $25^{\circ} 13^{\prime} \mathrm{N}$ latitude and $88^{\circ} 00^{\prime} \mathrm{E}$ to $89^{\circ} 10^{\prime} \mathrm{E}$ longitude. The average temperature ranges from $35^{\circ} \mathrm{C}$ to $25^{\circ} \mathrm{C}$ in the dry season and $9^{\circ} \mathrm{C}$ to $15^{\circ} \mathrm{C}$ in the winter season (Yasmin et al. 2013). This northwestern part of Bangladesh has been evolved during Pleistocene Terraces due to tectonic upliftment and /or exists as an erosional geomorphic feature (Rashid et al. 2015).

Area 02 was located atthe western districts of the country consisting Khulna, Barisal and western part of Dhaka divisions. The important feature of this area is the existence of Mangrove forest, "The Sundarbans". So, this area passess some unique vegetation. The Sundarban forest lies in the vast delta on the Bay of Bengal formed by the super confluence of the Ganges, Hooghly, Padma, Brahmaputra and Meghna rivers across the southern 
Bangladesh. The soil is saline in nature with the availability of less fresh water. The lower boundary of that area 02 is flooded by the Bay of Bengal. The major river channels are derived from this bay of Bengal along with the flow of Ganges.

Area 03 was located in the central and northern part of the country with the northern part of Dhaka division and Mymensingh division. The major characteristics of this area is the availability of Shal forest and it is mainly covered by the plain land. This area is the characterized of Pleistocene upliftment resulted Bhawal and Madhupur tract (Rashid et al. 2006). Some hilly areas including tectonically uplifted blocks created during Pleistocene are also the major characteristics in this area. This area is developed on the Ganges-Brahmaputra delta on late quaternary stratiphication (Goodbred and Kuehl, 2000).

Area 04 was located the northern part of Chittagong division and Sylhet. Northern Chittagong is a plane landed area with plenty of fresh water sources and many rivers crisscross acrossed while Sylhet division is mountainous with enormous number of tea garden with natural water fall. The major geological feature of that area is the Bengal basin. The Surma Basin is a sub-basin of the Bengal Basin situated in the northeastern part of Bangladesh. The basin is bounded on the north by the Shillong plateau, east and southeast by the ChittagongTripura fold belt of the Indo-Burman ranges, and west by The Indian Shield platform. This area is mainly created during Holocene (Mannan, 2002).

Area 05 includes the southern Chittagong division. This area is divided from others region of Bangladesh by the border of Meghna rivers. It is a mountainous area and the longest sea beach, Coxsbazar, is situated in this area. The area is mainly composed of Hill Tracts (CHT) in the south-eastern part of Bangladesh encompassing three hill districts: Rangamati, Khagrachari and Bandarban. It shares borders with Myanmar on the south and southeast, India on the north and northeast, and the Chittagong district of Bangladesh on the west. CHT is 


\section{Setting of Research Areas}

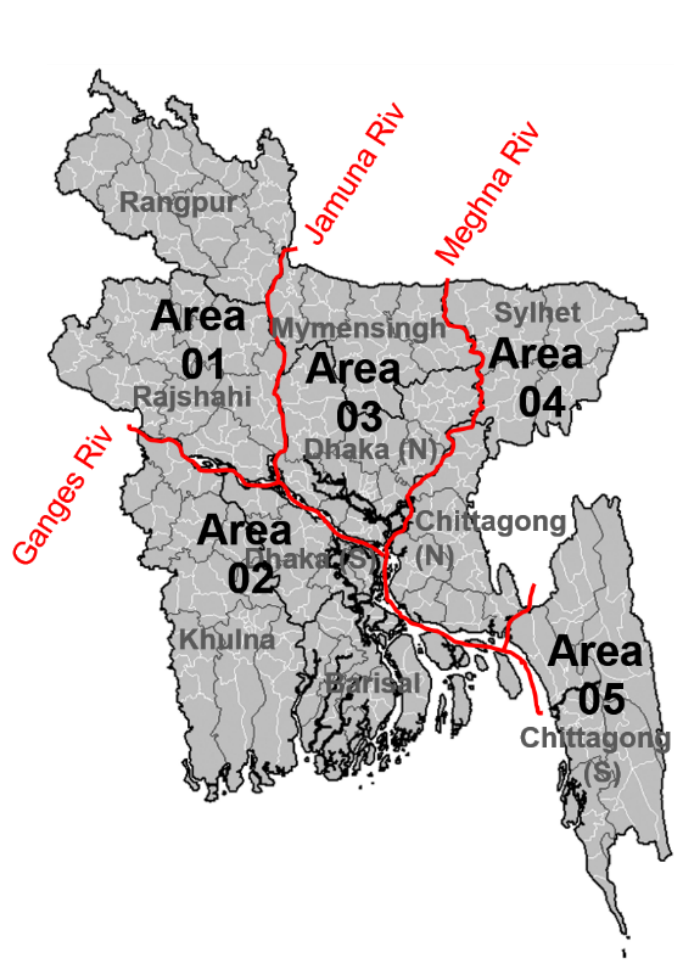

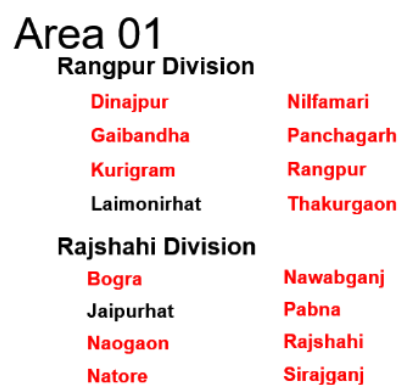

Area 02

Barisal Division Bargun Barisal

Bhola
Dhaka Division (Southern Part) Faridpur* Rajbari* Gopalganj* Shariatpur* Madaipur*

( ${ }^{*}$ Faridpur Division - plan)

Khulna Division

Bagerhat

Chuadanga

Jessore

Jhenaidaha Khulna
Area 03

Dhaka Division (Northern part)

Dhaka Munshiganj

Gazipur Narayanganj

Kishreganj Narsingdi

Manikganj Tangail

Mymensingh Division (4 Districts)

$\begin{array}{ll}\text { Jamalpur } & \text { Netrokona } \\ \text { Mymensingh } & \text { Sherpur }\end{array}$

\section{Area 04}

Chittagong Division (Northern part) Brahmanbaria* Feni* Chandpur* Lakshmipur* Comilla* Noakhali* (* Comilla Division - plan)

Sylhet Division Habiganj Snamgan Maulvibazar Sylhet

\section{Area 05}

Chittagong Division (Southern Part) Bandarban Khagrachari Chittagong Rangamati

The red letters show the District names where we sampled during March 2013 to December 2017.

Fig. 3.1 Sampling sites of 5 broad areas based on three main rivers in Bangladesh. The red line across the map showing the river flow that separated 5 broad areas in Bangladesh. In the text, red color indicating the district name from where sampling were done in each area. 
located between $21^{\circ} 40^{\prime}$ degrees and $23^{\circ} 47^{\prime}$ degrees north latitude and $91^{\circ} 40^{\prime}$ degrees and $92^{\circ} 42^{\prime}$ degrees east longitude. It is a unique territory with marked socio-economical and cultural differences from the rest of Bangladesh.

\section{Localities of $O$. smaragdina sampling}

A total of $95 \mathrm{O}$. smaragdina colonies had been collected from 87 localities of 47 districts belonging to 8 divisions of Bangladesh during September 2013 to December 2017. The locality position and detailed information are presented in Fig. 2.2 and Table 2.1.

\section{Sample preparation}

The collected samples from Bangladesh were analyzed for sequencing in the laboratory Institute of Tropical Agriculture of Kyushu University, Japan. The collected colonies of Oecophylla smaragdina were preserved in $99 \%$ ethanol prior to DNA extraction. 


\subsection{Molecular studies}

The sequential procedure for extraction of DNA to final sequencing is shown in the following diagram.

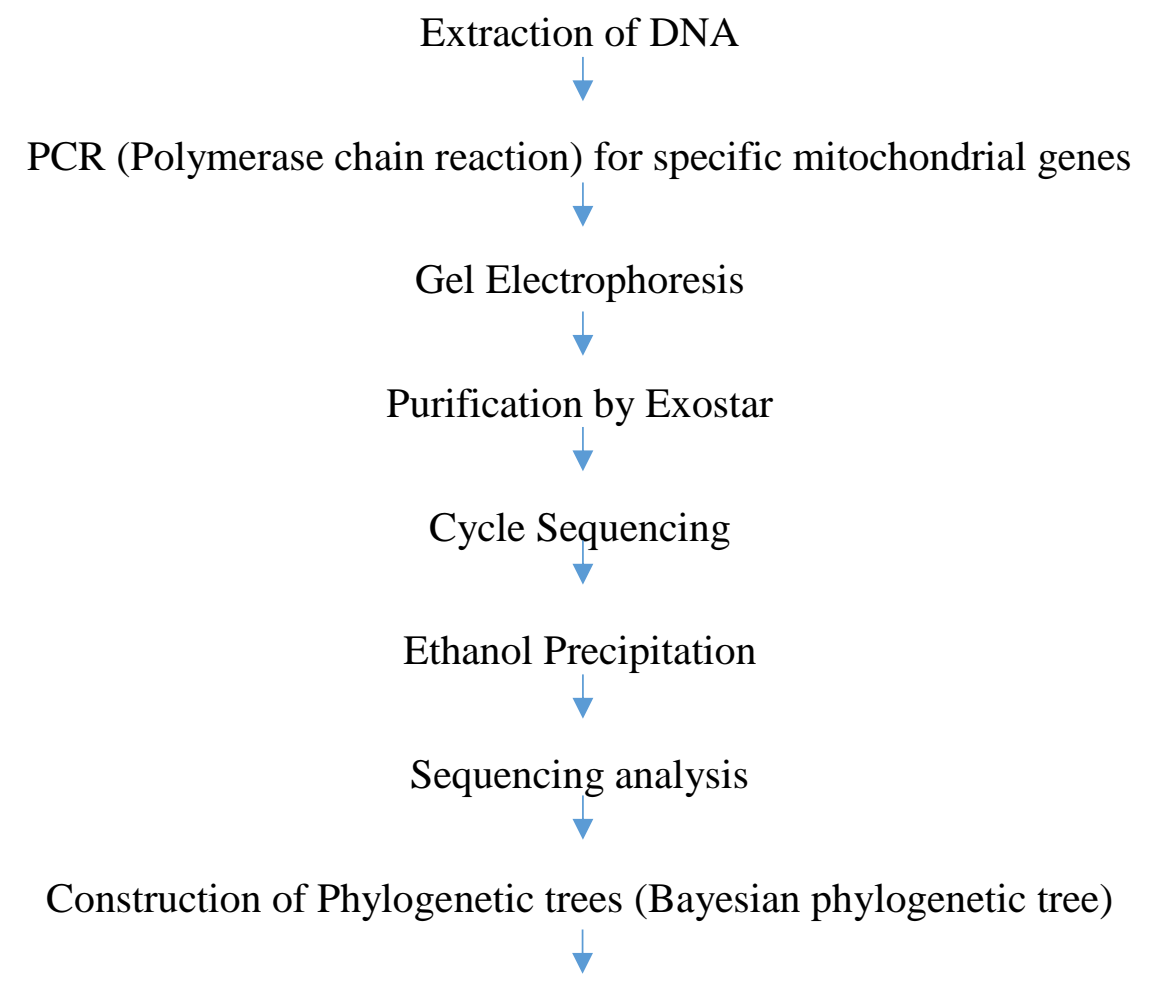

The inference is drawn by haplotype network analysis, divergence time estimation, Nuclear DNA (LWRh) analysis, and microsatellite study; The details will be in each chapter. 


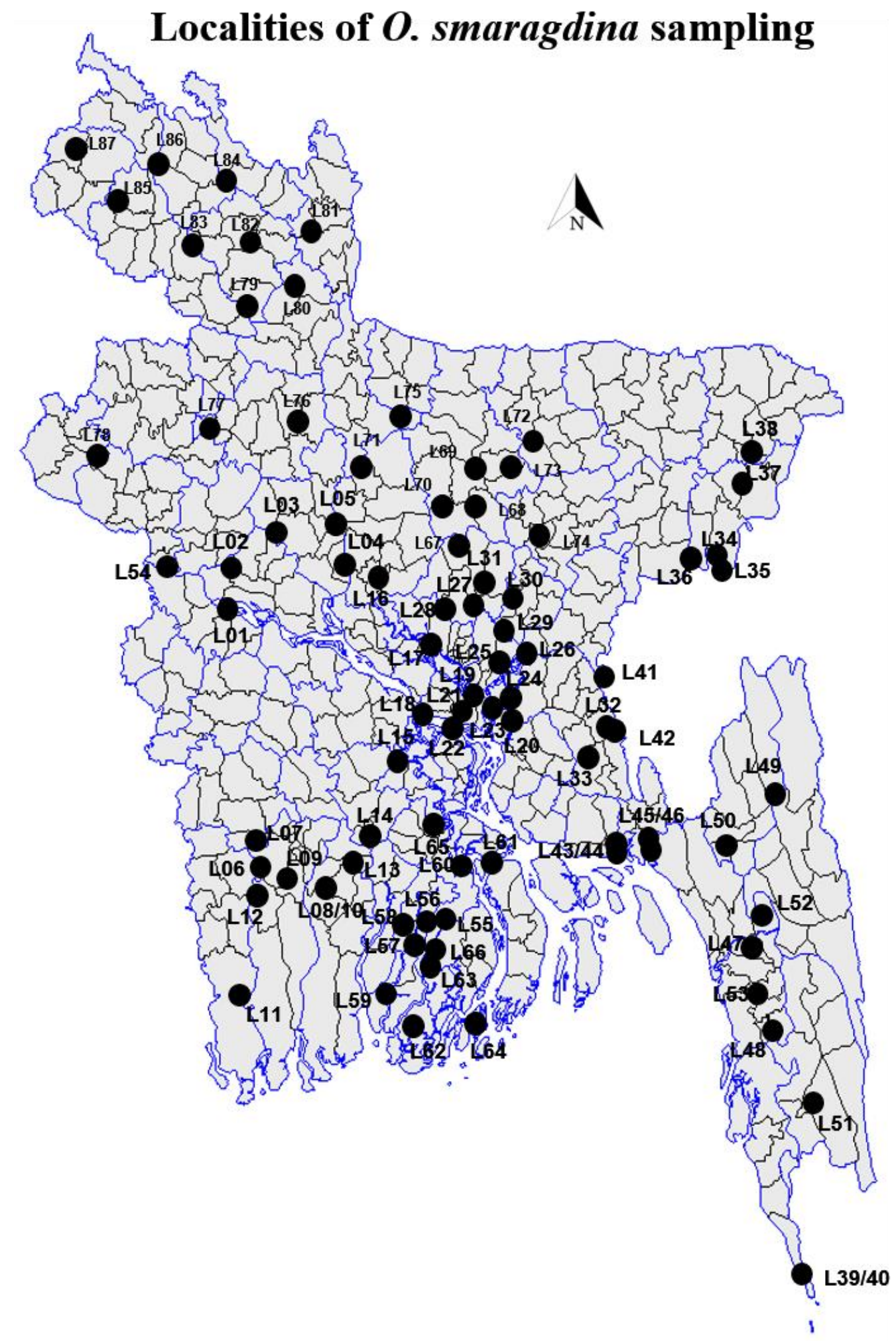

Fig. 3.2 Sampling sites of Oecophylla smaragdina in Bangladesh. 
Table 3.1 Detailed locality information of $O$. smaragdina sampling sites in Bangladesh

\begin{tabular}{|c|c|c|c|c|c|c|}
\hline Legends & $\begin{array}{l}\text { Locality } \\
\text { No. }\end{array}$ & Locality Name & $\begin{array}{l}\text { No. of } \\
\text { colonies }\end{array}$ & District & Division & $\begin{array}{l}\text { Area } \\
\text { Code }\end{array}$ \\
\hline $\mathrm{AB}$ & L01 & Ishwardi & 1 & Pabna & Rajshahi & $\mathrm{A} 01$ \\
\hline $\mathrm{ABC}$ & L02 & Bonpara & 1 & Natore & Rajshahi & $\mathrm{A} 01$ \\
\hline $\mathrm{AB}$ & L03 & Tarash & 1 & Sirajganj & Rajshahi & $\mathrm{A} 01$ \\
\hline $\mathrm{AB}$ & L04 & Chauhali & 1 & Sirajganj & Rajshahi & $\mathrm{A} 01$ \\
\hline $\mathrm{ABC}$ & L05 & $\begin{array}{l}\text { w side of Jamuna } \\
\text { Bridge }\end{array}$ & 1 & Sirajganj & Rajshahi & $\mathrm{A} 01$ \\
\hline $\mathrm{ABD}$ & L06 & Panjia & 1 & Jessore & Khulna & $\mathrm{A} 02$ \\
\hline $\mathrm{AB}$ & L07 & Monirampur & 1 & Jessore & Khulna & $\mathrm{A} 02$ \\
\hline $\mathrm{ABC}$ & L08 & Khulna Univ. Campus & 2 & Khulna & Khulna & $\mathrm{A} 02$ \\
\hline $\mathrm{AB}$ & L09 & Chuknagar & 1 & Khulna & Khulna & $\mathrm{A} 02$ \\
\hline $\mathrm{ABC}$ & L10 & Batiaghata & 1 & Khulna & Khulna & $\mathrm{A} 02$ \\
\hline $\mathrm{AB}$ & $\mathrm{L} 11$ & Atulia & 1 & Satkhira & Khulna & $\mathrm{A} 02$ \\
\hline $\mathrm{AB}$ & L12 & Modonpur & 1 & Satkhira & Khulna & $\mathrm{A} 02$ \\
\hline ACE & L13 & Mollahat Bazar & 1 & Bagerhat & Khulna & $\mathrm{A} 02$ \\
\hline $\mathrm{AB}$ & L14 & Pachuria & 1 & Gapalgonj & Dhaka & $\mathrm{A} 02$ \\
\hline $\mathrm{AB}$ & L15 & Bhanga & 1 & Faridpur & Dhaka & $\mathrm{A} 02$ \\
\hline $\mathrm{AB}$ & L16 & Elenga & 1 & Tangail & Dhaka & A03 \\
\hline $\mathrm{AB}$ & L17 & Kumrail & 1 & Dhaka & Dhaka & A03 \\
\hline $\mathrm{AB}$ & L18 & Thanamore & 1 & Dhaka & Dhaka & $\mathrm{A} 03$ \\
\hline $\mathrm{AB}$ & L19 & Ruhitpur & 1 & Dhaka & Dhaka & A03 \\
\hline A & L20 & Baluakandi & 1 & Munshiganj & Dhaka & $\mathrm{A} 03$ \\
\hline $\mathrm{ABCD}$ & $\mathrm{L} 21$ & Nimtali & 1 & Munshiganj & Dhaka & A03 \\
\hline $\mathrm{AC}$ & $\mathrm{L} 22$ & Bejgaon & 1 & Munshiganj & Dhaka & A03 \\
\hline A & $\mathrm{L} 23$ & Nababganj Bazar & 1 & Narayanganj & Dhaka & $\mathrm{A} 03$ \\
\hline A & L24 & Shiddirganj & 1 & Narayanganj & Dhaka & A03 \\
\hline $\mathrm{A}$ & $\mathrm{L} 25$ & Vulta & 1 & Narayanganji & Dhaka & $\mathrm{A} 03$ \\
\hline $\mathrm{ABCD}$ & L26 & Panchdona & 1 & Norsingdi & Dhaka & A03 \\
\hline $\mathrm{ABE}$ & $\mathrm{L} 27$ & Bhawal National Park & 2 & Gazipur & Dhaka & $\mathrm{A} 03$ \\
\hline $\mathrm{ABC}$ & L28 & Nurbag & 1 & Gazipur & Dhaka & A03 \\
\hline \multirow[t]{2}{*}{$\mathrm{ABC}$} & L29 & Charpara & 1 & Gazipur & Dhaka & A03 \\
\hline & L30 & Zamirarchala & 1 & Gazipur & Dhaka & $\mathrm{A} 03$ \\
\hline A & L31 & Rajbari & 1 & Gazipur & Dhaka & A03 \\
\hline $\mathrm{ABD}$ & L32 & Nimshar & 1 & Comilla & Chittagong & $\mathrm{A} 05$ \\
\hline $\mathrm{C}$ & L33 & Madhoyia & 1 & Comilla & Chittagong & A05 \\
\hline
\end{tabular}


Continued

$\begin{array}{lllllll}\text { ABCE } & \text { L34 } & \text { Tea Resort Center } & 3 & \text { Moulovibazar } & \text { Sylhet } & \text { A04 } \\ \text { AB } & \text { L35 } & \text { Lauachra National } & 1 & \text { Moulovibazar } & \text { Sylhet } & \text { A04 } \\ & & \text { Park } & & & & \\ \text { ABC } & \text { L36 } & \text { Bahubal } & 1 & \text { Habiganj } & \text { Sylhet } & \text { A04 } \\ \text { ABCD } & \text { L37 } & \text { Tarau } & 1 & \text { Sylhet } & \text { Sylhet } & \text { A04 } \\ \text { ABC } & \text { L38 } & \text { Doradarpur } & 1 & \text { Sylhet } & \text { Sylhet } & \text { A04 } \\ \text { AB } & \text { L39 } & \text { Marishbunia } & 1 & \text { Cox's Bazar } & \text { Chittagong } & \text { A05 } \\ & \text { L40 } & \text { Noakhali para } & 1 & \text { Cox's Bazar } & \text { Chittagong } & \text { A05 } \\ \text { AB } & \text { L41 } & \text { Mondabag } & 1 & \text { Bramhanbaria } & \text { Chittagong } & \text { A04 } \\ \text { A } & \text { L42 } & \text { Jogotpur } & 1 & \text { Comilla } & \text { Chittagong } & \text { A04 } \\ \text { AB } & \text { L43 } & \text { Sebarhat } & 1 & \text { Noakhali } & \text { Chittagong } & \text { A04 } \\ \text { A } & \text { L44 } & \text { Senbag Upozilla } & 1 & \text { Noakhali } & \text { Chittagong } & \text { A04 } \\ & & \text { Hospital } & & & & \\ \text { ABC } & \text { L45 } & \text { Mohipal } & 1 & \text { Feni } & \text { Chittagong } & \text { A04 } \\ \text { ABDE } & \text { L46 } & \text { Mohipal Primary } & 1 & \text { Feni } & \text { Chittagong } & \text { A04 }\end{array}$

School

$\begin{array}{lllllll}\text { A } & \text { L47 } & \text { Raujan Bazar } & 1 & \text { Chittagong } & \text { Chittagong } & \text { A05 } \\ \text { ABC } & \text { L48 } & \text { Satkania } & 1 & \text { Chittagong } & \text { Chittagong } & \text { A05 } \\ \text { ABC } & \text { L49 } & \text { Dighinala HRC } & 1 & \text { Khagrachari } & \text { Chittagong } & \text { A05 } \\ \text { ABE } & \text { L50 } & \text { Matiranga Dhibi } & 1 & \text { Khagrachari } & \text { Chittagong } & \text { A05 } \\ \text { AB } & \text { L51 } & \text { Ruma Karai } & 1 & \text { Bandarban } & \text { Chittagong } & \text { A05 } \\ \text { ABCD } & \text { L52 } & \text { Kawkhali Bazar } & 1 & \text { Rangamati } & \text { Chittagong } & \text { A05 } \\ \text { A } & \text { L53 } & \text { Patia } & 1 & \text { Chittagong } & \text { Chittagong } & \text { A05 } \\ \text { ABD } & \text { L54 } & \text { Thanapara Sadah } & 1 & \text { Rajshahi } & \text { Rajshahi } & \text { A01 } \\ \text { AB } & \text { L55 } & \text { Nalchiti prim. sch. } & 1 & \text { Jhalokati } & \text { Barisal } & \text { A02 } \\ & & \text { field } & & & & \\ \text { AB } & \text { L56 } & \text { BRAC more } & 1 & \text { Jhalokati } & \text { Barisal } & \text { A02 } \\ \text { ABCD } & \text { L57 } & \text { Baghribazar } & 1 & \text { Jhalokati } & \text { Barisal } & \text { A02 } \\ \text { ABCD } & \text { L58 } & \text { Kawkhali Upz P } & 1 & \text { Pirojpur } & \text { Barisal } & \text { A02 } \\ & & \text { Chottor } & & & & \\ \text { ABC } & \text { L59 } & \text { Shakharikathi } & 1 & \text { Pirojpur } & \text { Barisal } & \text { A02 } \\ \text { A } & \text { L60 } & \text { Rupatoli } & 1 & \text { Barisal } & \text { Barisal } & \text { A02 } \\ \text { ABC } & \text { L61 } & \text { Patarhat } & 1 & \text { Barisal } & \text { Barisal } & \text { A02 } \\ \text { A } & \text { L62 } & \text { Barguna Sadar bus } & 1 & \text { Barguna } & \text { Barisal } & \text { A02 } \\ & & \text { stand } & & & & \text { A02 } \\ \text { AD } & \text { L63 } & \text { PSTU } & 1 & \text { Patuakhali } & \text { Barisal } & \text { A02 } \\ \text { AB } & \text { L64 } & \text { Panpatti } & 1 & \text { Patuakhali } & \text { Barisal } & \end{array}$


Continued

\begin{tabular}{|c|c|c|c|c|c|c|}
\hline $\mathrm{ABD}$ & L65 & $\begin{array}{l}\text { Agailjhara Uni P } \\
\text { office }\end{array}$ & 1 & Barisal & Barisal & A02 \\
\hline ABED & L66 & Mohespur & 1 & Barisal & Barisal & $\mathrm{A} 02$ \\
\hline $\mathrm{ABCE}$ & L67 & Bhaluka Bazar & 1 & Mymensingh & Mymensingh & A03 \\
\hline $\mathrm{ABD}$ & L68 & $\begin{array}{l}\text { Trishal Primary } \\
\text { School }\end{array}$ & 1 & Mymensingh & Mymensingh & A03 \\
\hline $\mathrm{ABC}$ & L69 & BAU Campus & 1 & Mymensingh & Mymensingh & A03 \\
\hline $\mathrm{ABC}$ & L69 & $\begin{array}{l}\text { BAU, Sesh Matha } \\
\text { More }\end{array}$ & 1 & Mymensingh & Mymensingh & A03 \\
\hline $\mathrm{AB}$ & L70 & Nandail & 1 & Mymensingh & Mymensingh & A03 \\
\hline $\mathrm{ABCD}$ & L71 & $\begin{array}{l}\text { Sarisha Bari High } \\
\text { School }\end{array}$ & 1 & Jamalpulr & Mymensingh & A03 \\
\hline $\mathrm{AC}$ & L71 & Bazar Pukur & 1 & Jamalpur & Mymensingh & A03 \\
\hline $\mathrm{ABC}$ & L72 & Sadar Hospital & 1 & Netrokona & Mymensingh & A03 \\
\hline $\mathrm{ABC}$ & $\mathrm{L} 72$ & Sadar Primary School & 1 & Netrokona & Mymensingh & A03 \\
\hline $\mathrm{AB}$ & L73 & $\begin{array}{l}\text { Gauripur Upz } \\
\text { Complex }\end{array}$ & 1 & Mymensingh & Mymensingh & A03 \\
\hline $\mathrm{AB}$ & L74 & Higher par & 2 & Kishorgonj & Mymensingh & $\mathrm{A} 03$ \\
\hline $\mathrm{AB}$ & L75 & Sadar Thana more & 1 & Sherpur & Mymensingh & A03 \\
\hline $\mathrm{ABC}$ & L76 & Dhunat Upz. Chattor & 1 & Bogra & Rajshahi & A01 \\
\hline $\mathrm{ABC}$ & L77 & Municipality Orchard & 1 & Naogaon & Rajshahi & $\mathrm{A} 01$ \\
\hline $\mathrm{ABC}$ & L78 & Nijampur & 1 & $\begin{array}{l}\text { Chapainawab } \\
\text { ganj }\end{array}$ & Rajshahi & $\mathrm{A} 01$ \\
\hline $\mathrm{ABC}$ & L79 & Hakimpur Nursery & 1 & Dinajpur & Rangpur & A01 \\
\hline $\mathrm{ABC}$ & L80 & Shibpur & 1 & Gaibandha & Rangpur & A01 \\
\hline $\mathrm{ABC}$ & L81 & Gharialdanga & 1 & Kurigram & Rangpur & A01 \\
\hline $\mathrm{ABC}$ & L82 & $\begin{array}{l}\text { Rasulpur School } \\
\text { ground }\end{array}$ & 1 & Rangpur & Rangpur & $\mathrm{A} 01$ \\
\hline $\mathrm{ABC}$ & L83 & $\begin{array}{l}\text { Saidpur airport } \\
\text { surrounding }\end{array}$ & 1 & Nilfamari & Rangpur & A01 \\
\hline $\mathrm{ABC}$ & L84 & Barobala & 1 & Rangpur & Rangpur & A01 \\
\hline $\mathrm{ABC}$ & L85 & $\begin{array}{l}\text { Pirganj fire station } \\
\text { orchard }\end{array}$ & 1 & Thakurgaon & Rangpur & A01 \\
\hline $\mathrm{ABC}$ & L86 & Debiganj bus stand & 1 & Panchagar & Rangpur & A01 \\
\hline $\mathrm{ABC}$ & L87 & $\begin{array}{l}\text { Atwari sadar thana } \\
\text { more }\end{array}$ & 1 & Panchagar & Rangpur & A01 \\
\hline
\end{tabular}

$\mathrm{A}=$ used in phylogenetic analysis, $\mathrm{B}=$ used in Haplotype network study, $\mathrm{C}=$ in Nuclear DNA study, $\mathrm{D}=$ in Divergence time estimation, $\mathrm{E}=$ in Microsatellite study 


\section{Extraction of DNA}

Genomic DNA was extracted from the fore, middle and hind legs of specimens that were preserved in $99 \%$ ethanol by using QIAGEN DNeasy Blood and Tissue kit (Qiagen, Maryland, USA) following manufacturer's instruction. Samples were vortexed by adding $180 \mu 1$ Buffer ATL and $20 \mu \mathrm{l}$ proteinase K. Sample were incubated at $55^{\circ} \mathrm{C}$ for 48 hours. DNA extraction was completed by adding two wash buffer AW1 and wash buffer AW2 and Buffer AE and lysis buffer AL and elusion buffer AE, as per manufacturer instruction. All centrifugation steps were completed at room temperature. The colony mates of the specimens used for DNA analysis were preserved in the laboratory of Institute of Tropical Agriculture, Kyushu University after DNA extraction.

\section{PCR (Polymerase chain reaction)}

Amplification of mitochondrial DNA was done by polymerase chain reaction (PCR) using TaKaRa Ex Taq PCR kit, according to the manufacturer's instructions. The kit contains 10X Ex Taq Buffer (20mM Mg${ }^{2+}$ plus) and dNTP mixture (2.5mM each). The storage buffer contain $20 \mathrm{mM}$ Tris- $\mathrm{HCl}$ (pH 8.0), $100 \mathrm{mM} \mathrm{KCl,} \mathrm{0.1mM} \mathrm{EDTA,} \mathrm{1mM} \mathrm{DTT,} \mathrm{0.5 \%} \mathrm{Tween} \mathrm{20,} \mathrm{0.5 \%}$ Nonidet P-40 and 50\% glycerol. dNTP mixtures contains TAPS, $\mathrm{KCl}, \mathrm{MgCl}_{2}, \mathrm{DTT}$, dATP, dGTP, dCTP with activated salmon sperm DNA. Reaction mixtures for PCR for $50 \mu 1$, TaKaRa Ex Taq $(0.25 \mu \mathrm{l}), 10 \mathrm{XExTaq}$ Buffer $(5 \mu \mathrm{l})$, dNTP mixture $(4 \mu \mathrm{l})$, a pair of oligonucleotide primers (0.2-1.0 $\mu \mathrm{M}$; Table 2) and sterilized distilled water (up to $50 \mu \mathrm{l}$ ) were run in Biometra Genomics and Proteomics analyzer with the following instructional status. The thermal cycling parameters for $C y t b$ and $C O I$ basically followed the protocols established by (Crozier and Crozier, 1993) and (Sameshima et al., 1999), including $95^{\circ} \mathrm{C}$ for $5 \mathrm{~min}$ for initial denaturation, 35 cycles of dissociation $\left(92^{\circ} \mathrm{C}, 1 \mathrm{~min}\right)$, annealing $\left(50{ }^{\circ} \mathrm{C}\right.$ for $C y t b$ and $54{ }^{\circ} \mathrm{C}$ for $\left.C O I, 1 \mathrm{~min}\right)$, and extension $\left(70{ }^{\circ} \mathrm{C}, 2 \mathrm{~min}\right)$. The primers used for amplification are identical to primers 
reported by Crozier et al. (1995), Lunt et al. (1996), Azuma et al. (2002), and Azuma et al. (2006) (Table 3.2). For LW Rh, the PCR parameters were the same as for mitochondrial genes; thermal cycling parameters were nearly the same, except the annealing temperature was $60^{\circ} \mathrm{C}$ for this region. The sequences and positions of mitochondrial DNA of the primers for PCR and sequencing are shown in Table 3.3 and Table 3.4.

\section{Gel electrophoresis}

After PCR, gel electrophoresis was performed to check the result. The gel was prepared

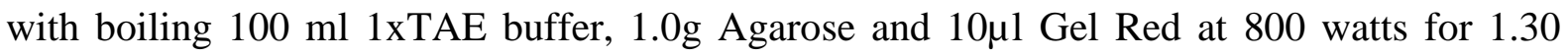
minutes. Then the PCR product having mixed with $6 \mathrm{X}$ coding buffer was put into the gel of gel electrophoresis plate for 20 minutes to compare the results of the PCR products with the standard product that containing $100 \mathrm{bp}$ DNA ladder.

\section{Exostar}

For Enzymatic PCR and sequencing clean-up, Illustra and ExoProStar were followed according to the instruction of the manufacturer GE Healtcare. Exonuclease ( 1 reaction $\mu 1^{-1}$, Solution in 20mM Tris-HCl (pH 7.5), 0.1mM EDTA, 1mM DTT, 50\% (v/v) glycerol) and Alkaline phosphate (1 reaction $\mu \mathrm{l}^{-1}$, Solution in 20Mm HEPES-NaOH (pH 7.4), $1 \mathrm{mM} \mathrm{MgCl} 2$, $0.1 \mathrm{mM} \mathrm{ZnCl} 2,0.1 \%(\mathrm{v} / \mathrm{v})$ Triton X-100, $50 \%$ (v/v) glycerol were added to the PCR product and incubate $37^{\circ} \mathrm{C}$ for 15 minutes and $80^{\circ} \mathrm{C}$ for 15 minutes to inactivate the enzymes.

\section{Cycle sequencing}

For cycle sequencing, ABI PRISM Big Dye Terminator v3.1 Cycle sequencing kits from Applied Biosystems were used in an automated sequencer. The operational status that 
Table 3.2 Primers for amplifying and sequencing mitochondrial Cytb and COI and nuclear genes. The positions of primers for mitochondrial genes follow the complete sequence of mitochondrial DNA of Apis mellifera (Crozier and Crozier, 1993)

\begin{tabular}{|c|c|c|c|c|}
\hline Region & Name & Direction & Sequence $\left(5^{\prime}-3^{\prime}\right)^{\mathrm{a}}$ & Position \\
\hline \multirow[t]{5}{*}{ Cytb } & $\mathrm{Cb}^{\mathrm{d}}$ & Forward & TATGTACTACCATGAGGACAAATATC (1) & $11400-11425$ \\
\hline & $\mathrm{tRs}^{\mathrm{c}}$ & Reverse & TATTTCTTTATTATGTTTTCAAAAC (1) & $12250-12226$ \\
\hline & $\mathrm{Cb} 1.5 \mathrm{~F}^{\mathrm{b}}$ & Forward & GAGATTTATATAAAATTCCT & $11596-11616$ \\
\hline & $\mathrm{Cb} 3^{\mathrm{b}}$ & Forward & CCAATTCATATTCAACC & $11777-11794$ \\
\hline & $\mathrm{Cb} 4 \mathrm{R}^{\mathrm{d}}$ & Reverse & CTCATATTTTTATAATTAGAAATGAT & $12100-12126$ \\
\hline \multirow[t]{4}{*}{ COI } & COI $1-3^{d}$ & Forward & ATAATTTTTTTTATAGTTATACC (2) & $1981-2002$ \\
\hline & $\mathrm{COI} 2-4^{\mathrm{d}}$ & Reverse & TCCTAAAAAATGTTGAGGAAA (2) & $3063-3083$ \\
\hline & $\mathrm{COI} 66 \mathrm{OR}^{\mathrm{b}}$ & Reverse & GCTGAAGTAAAATAAGCTCGTG & $2688-2710$ \\
\hline & $\mathrm{COI} 2-1^{\mathrm{b}}$ & Forward & CTTTATCAACATTTATTTTGATTTTT (2) & $2481-2499$ \\
\hline \multirow[t]{6}{*}{ LW Rh } & $\mathrm{LW} \mathrm{RhF}^{\mathrm{d}}$ & Forward & AATTGCTATTAYGARACNTGGGT (3) & NA \\
\hline & $\mathrm{LW} \mathrm{RhR}{ }^{\mathrm{d}}$ & Reverse & ATATGGAGTCCANGCCATRAACCA (3) & NA \\
\hline & LR $798 \mathrm{~F}^{\mathrm{d}}$ & Forward & GCH GCY CAY GAG AAG AAY ATG CG (4) & NA \\
\hline & LR $1047 \mathrm{R}^{\mathrm{d}}$ & Reverse & $\begin{array}{l}\text { GG ATT RTA YAC RGC RTT GGC TTT } \\
\text { BGC(4) }\end{array}$ & NA \\
\hline & LR $482 \mathrm{FCR}^{\mathrm{d}}$ & Forward & ATA TGG ACG ATG ACR ATG ATC GC(4) & NA \\
\hline & $\mathrm{LR} 855 \mathrm{R}^{\mathrm{d}}$ & Reverse & GA TCG YAR VGA AGC RAC GTT CAT(4) & NA \\
\hline
\end{tabular}

a (1) (Crozier et al. 1995), (2) (Lunt et al. 1996) ${ }^{\text {b } U s e d ~ o n l y ~ f o r ~ s e q u e n c e ; ~(C a m e r o n ~ e t ~ a l . ~ 2001) ~}$

(Cameron and Williams, 2003), (3) (Mardulyn and Cameron, 1999), (4) (Blaimer, 2012)

${ }^{\mathrm{c}}$ Used for PCR; ${ }^{\mathrm{d}}$ Used for both PCR and sequence 
Table 3.3 The operational status of PCR and Cycle sequencing

\begin{tabular}{cccccc}
\hline \multicolumn{5}{c}{ PCR for Cytb } \\
\hline Steps & $\begin{array}{c}\text { Times } \\
(\mathrm{X})\end{array}$ & ${ }^{0} \mathrm{C}$ & $\mathrm{M}: \mathrm{S}$ & $\begin{array}{c}\text { Go } \\
\text { to }\end{array}$ & Loops \\
\hline 1 & & 95.0 & $05: 00$ & & \\
2 & & 92.0 & $01: 00$ & & \\
3 & 35 & 50.0 & $01: 00$ & & \\
4 & & 70.0 & $02: 00$ & 2 & 34 \\
5 & & 70.0 & $01: 00$ & & \\
6 & & 4.0 & Pause & \\
\hline
\end{tabular}

\begin{tabular}{cccccc}
\hline \multicolumn{5}{c}{ PCR for CO1 } \\
\hline Steps & $\begin{array}{c}\text { Times } \\
(\mathrm{X})\end{array}$ & ${ }^{0} \mathrm{C}$ & $\mathrm{M}: \mathrm{S}$ & $\begin{array}{c}\text { Go } \\
\text { to }\end{array}$ & Loops \\
\hline 1 & & 95.0 & $05: 00$ & & \\
2 & 35 & 92.0 & $01: 00$ & & \\
3 & & 54.0 & $01: 00$ & & \\
4 & & 70.0 & $02: 00$ & 2 & 34 \\
5 & & 70.0 & $01: 00$ & & \\
6 & & 4.0 & Pause & & \\
\hline
\end{tabular}

\begin{tabular}{ccc}
\hline \multicolumn{3}{c}{ Exoster } \\
\hline Steps & ${ }^{0} \mathrm{C}$ & M:S \\
1 & 37.0 & $15: 00$ \\
2 & 80.0 & $15: 00$ \\
3 & 4.0 & Pause \\
\hline
\end{tabular}

\begin{tabular}{cccccc}
\hline \multicolumn{5}{c}{ Cycle sequence } \\
\hline Steps & $\begin{array}{c}\text { Times } \\
(\mathrm{X})\end{array}$ & ${ }^{0} \mathrm{C}$ & $\mathrm{M}: \mathrm{S}$ & $\begin{array}{c}\text { Go } \\
\text { to }\end{array}$ & Loops \\
1 & & 94.0 & $00: 30$ & & \\
2 & 25 & 96.0 & $00: 30$ & & \\
3 & & 50.0 & $04: 50$ & 2 & 24 \\
4 & & 4.0 & 99.59 & & \\
\hline
\end{tabular}


performed is presented in Table 2.4. Cycle sequencing and ethanol precipitation were done for final sequencing analysis by ABI 3100 Avant DNA Sequencer (Applied Biosystems).

\section{Ethanol precipitation}

After completing the cycle sequencing, the products were added with sodium acetate and 99\% ethanol. Then flash together and centrifuge at $15000 \mathrm{rpm}$ for 10 minutes, removed all the solutions and then added $70 \%$ ethanol. Recentrifuged again at $15000 \mathrm{rpm}$ for 5 minutes and then total ethanol was excluded. Then the product was kept for $90^{\circ} \mathrm{C}$ for 2 minutes to remove moisture.

\section{Sequencing}

For melting DNA of the ethanol precipitated product, Hidiformamid was added and heat shock at $94^{\circ} \mathrm{C}$ for 2 minutes was applied. Then it was placed in the final sequencer analyzer to get the final sequence by using ABI 3100 Avant DNA Sequencer (Applied Biosystems). 


\subsection{Detailed flow chart of the experiments}

Taking out the sample with a sterilized needle and placed into the tissue paper for dry $\downarrow$

It was kept in the $1.5 \mathrm{ml}$ tube and waiting for dry

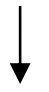

Destroying ant body; Addition of $180 \mu \mathrm{l}$ ATL Buffer $+20 \mu \mathrm{l}$ Proteinase- k Mixing

Placed in the heat Block at $55^{\circ} \mathrm{Cm}$ for 48 hours

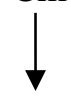

Taken from heat block and $200 \mu \mathrm{l}$ Buffer AL added (Vortexing + Rotating)

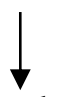

Incubate at $70{ }^{\circ} \mathrm{C}$ for 10 mins and then $210 \mathrm{ul}$ of $99 \%$ ethanol added (Vortexing)

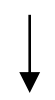

\section{Direct pouring}

Pipet the mixture into a DNeasy Mini Spin column.

Placed in a $2 \mathrm{ml}$ collecting tube, centrifuge at $8000 \mathrm{rpm}$ for $1 \mathrm{~min}$.

Discarded the flow through and collection tube. (Room Temperature $20^{\circ} \mathrm{C}$ )

Place the spin column in a new $2 \mathrm{ml}$ collection tube. 500 ul Buffer AWL added

Centrifuged at $800 \mathrm{rpm}$ for $1 \mathrm{~min}$

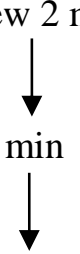

Placed the spin column in a new $2 \mathrm{ml}$ collection tube.

Add 500 ul Buffer AW2 and centrifuge for 3 mins at $15000 \mathrm{rpm}$

Transferred the spin column to a new $1.5 \mathrm{ml}$ or $2 \mathrm{ml}$ micro centrifuge tube.

Elute the DNA by adding $30 \mu \mathrm{l}$ Buffer AE to the center of the spin column membrane. Incubate at the room temperature for $1 \mathrm{~min}$. Centrifuge $8000 \mathrm{rpm}$ for $1 \mathrm{~min}$. 
Combination of MilliQ + 10x E7Q Buffer + DNTP Buffer + Primar (forward and reverse)

+ Ex Taq. All in one tube $(0.6 \mathrm{ml}$ tube) was done

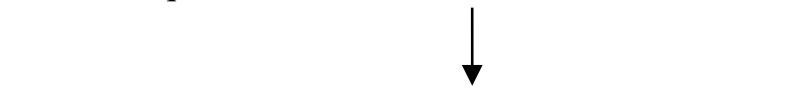

$9 \mu \mathrm{l}$ taken from the mixed solution of $0.6 \mathrm{ml}$ tube and put it into $0.2 \mu \mathrm{l}$ micro tube according to the number of samples. Extracted DNA solution of $1 \mathrm{ul}$ was added by Pipetting and then flashed in refrigerated centrifuge machine at $4^{\circ} \mathrm{C}$.

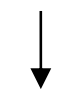

Placed in the PCR machine with set programing

\section{After PCR:}

Parafilm was taken and dropped 6x coding Buffer of $1.5 \mu 1$ and PCR product $4 \mu 1$

$4 \mu 1$ Drop of 100 bp DNA ladder to the additional one of the Parafilm.

Poured into stained gel keeping on the plate and started Gel Electrophoresis:

For the preparation of gel, $100 \mathrm{ml}$ 1XTAE Buffer $+1 \mathrm{~g}$ Agarose $+10 \mu 1$ ethyl bromide (staining) was added Boiling to the oven at 800 watts for 1:30 min.

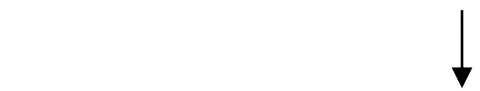

Taken the PCR product after the successful result of gel electrophoresis

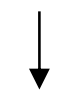

Add $1 \mu$ alkaline phosphate and $1 \mu$ l exonuclease

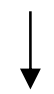

Placed in the PCR machine for summer cycle for 30 mins

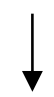

For cycle sequencing $1 \mu \mathrm{l}$ exostar product of each sample are taken in $0.2 \mathrm{ml}$ tube<smiles>C1CCCCC1</smiles>

MilliQ, dilution buffer, big dye buffer, and primer are mixed in an aforesaid concentration

$3.9 \mu 1$ mixture was added with each $1 \mu 1$ of Exostar product and placed for cycle sequencing 
After completion of cycle sequencing add 2 more chemicals

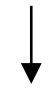

Sodium acetate of $1.5 \mu 1$ and $99 \%$ ethanol of $13.5 \mu 1$

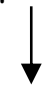

Flashed and wait for 5 minutes

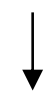

Centrifuged 10 mins @ 15000 rpm (placed carefully in proper direction)

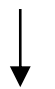

Removed all solution carefully (around $20 \mu \mathrm{l}$ )

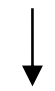

Added70\% Ethanol, @ $50 \mu 1$ and centrifuge 5 mins @ 15000 rpm

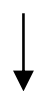

Exclusion of ethanol completely and kept in the PCR machine at $90^{\circ} \mathrm{C}$ for 2 mins to remove moisture

Taking out the product and add $10 \mu \mathrm{l}$ hidiformaid to melt DNA in each tube and shake to mix properly

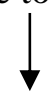

$94^{0} \mathrm{C}$ for 2 mins summer cycle machine (heat shock 02)

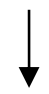

Pour into the Analyzer box 96 wall reaction plate Placed in DNA sequencing analyzer

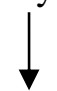

\section{Collection of Data}

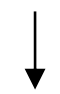

Sequencing analysis was done by using Vector NTI Advance ver.11.5 software.

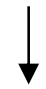

Construction of NJ tree and Maximum likelihood tree by using MEGA 6.0

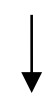

Selection of the best fit model by MrModel test (PAUP b.0)

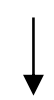

Bayesian analysis for phylogenetic study (MrBayes)

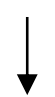

Haplotype network analysis by (TCS 2.1) 
Haplotype network drawing by using POPART 1.7

$\downarrow$

Divergence time estimation by MCMC tree using COI mitochondrial sequences

Checking for the nucleotide site change of Indian and SE Asian type between Mitochondrial and Nuclear DNA (MEGA 7.0)

Analysis of the STR by Microsatellite study (Peak scanner 1.0)

$\downarrow$

Finding the identical allele for Indian and SE Asian type of weaver ant by overserving

Single and double peak using electropherogram feature (Peak scanner 1.0)

Fig. 3.3 Detailed flow chart of the experiments 


\section{CHAPTER 4}

PHYLOGENETIC RELATIONSHIP INFERRED
FROM MITOCHONDRIAL DNA OF OECOPHYLLA
SMARAGDINA IN BANGLADESH




\section{CHAPTER 4}

\section{Phylogenetic relationship inferred from mitochondrial DNA of Oecophylla smaragdina in Bangladesh}

To reveal the molecular phylogeny of the Asian weaver ant in Bangladesh, the following experiments were conducted.

4.1 Revealing the distribution pattern of $O$. smaragdina in Bangladesh by phylogenetic study using mtDNA genes

4.2 Providing the haplotypes and distribution of the haplotype network of $O$. smaragdina in Bangladesh

In this chapter, we will discuss the results of each experiment in details.

\subsection{Revealing the distribution pattern of $O$. smaragdina in Bangladesh}

\subsubsection{Introduction}

The weaver ant, O. smaragdina is a broadly distributed genus and has the ability to disperse over ocean islands without human interventions. Azuma et al. (2002) first analyzed populations of $O$. smaragdina using molecular data and samples, including the $O$. smaragdina from Bangladesh. In addition, she added comprehensive samples of $O$. smaragdina from India, Southeast Asia and Australia, Azuma et al. (2006) proposed an outline of the phylogeography of $O$. smaragdina and categorized the sampled populations into 7 major clades: group 1 from India; group 2 from Southeast Asian mainland including the Indochinese and Malayan 
Peninsulas, as well as the Greater Sunda Islands; group 3 from the Philippines; group 4 from Flores; group 5 from Sulawesi; group 6 from Halmahera; group 7 from Australia and New Guinea. Hereafter I will refer the Azuma et al. (2006) group 1 as Indian type and Azuma et al. (2006) group 2 as SE Asian type. Asaka (2010) extended the survey of O. smaragdina to South Asia and collected several samples from India and Sri Lanka. Her phylogenetic analysis showed that all analyzed samples belong to Indian clade with low levels of sequence divergence.

Azuma et al. (2006) characterized the mitochondrial sequence identity of the Bangladesh populations as belonging to the Southeast Asian clade in spite of the geographical proximity of Bangladesh to India. They hypothesized the existence of an Indian refuge for the independence of group 1 from group 2, and concluded that if the Indian population originated from the Indian refuge and Bangladesh Based on those data, Bangladesh is considered a major transition zone between Indian and Southeast Asian populations. This is the unique case of population boundaries without any distinguished geographical borders (e.g., deep sea or high mountains), although the seven groups of $O$. smaragdina based on haplotype grouping by Azuma et al. (2006) are geographically bordered by the sea. A recent study emphasized the site records for O. smaragdina in Bangladesh (Wetterer, 2017). Similar trends were also observed in the case of Asian elephants, where two highly divergent mtDNA of Asian elephants overlapped geographically due to secondary contact after glaciation during Pleistocene (Vidya et al. 2009).

In recent phylogeographic study Rahman et al. (2017b) identified the western Bangladeshi populations as Indian type. This is the first report of occurring Indian type in Bangladesh and this evidence proved that in Bangladesh, there is no such border to restrict the occurrence of Indian type in Bangladesh. 
The purpose of the present experiment was to examine the phylogenetic relationship of weaver ant populations from northern, eastern and central part of Bangladesh for covering its distribution range in the country. The previous sampling by Azuma et al. (2006) was limited to only one site of Nurbag, Gazipur, located at the central part of Bangladesh, distinguished as Southeast Asian clades. However, O. smaragdina from the western parts of Bangladesh were identified as Indian clade. This result suggests the importance of phylogenetic study of central and eastern Bangladeshi populations to identify the nature of distribution.

\subsubsection{Materials and method}

\section{Sampling and preparation of specimens}

In 2013 to 2017 we collected adult Oecophylla smaragdina workers from 95 colonies at 87 localities in 47 districts belonging to 8 divisions of Bangladesh. The locality information in details are presented in Table 3.1 in the general methodology chapter. The specimens were preserved in $99 \%$ ethanol prior to DNA extraction.

\section{Molecular study}

Genomic DNA was extracted from the legs of specimens that were preserved in alcohol by using QIAGEN DNeasy Blood and Tissue kit (Qiagen, Maryland, USA). Amplification of both mitochondrial and nuclear DNA was done by polymerase chain reaction (PCR). The primers used for amplification are identical to primers reported by Crozier et al. (1994), Lunt et al. (1996), Azuma et al. (2002), and Azuma et al. (2006). For, mitochondrial DNA analysis,

Primers for the Cytb gene fragment were $\mathrm{Cb} 1$ (5'TATGTACTACCATGAGGACAAATATC'3) and tRs (5'TATTTCTTTATTATGTTTTCAAAAC'3). For the COI gene fragment, COI 1-3 
(5’ATAATTTTTTTTATAGTTATACC’3)

and

COI

(5'TCCTAAAAAATGTTGAGGAAA'3) were used as forward and reverse primers, respectively by Crozier and Crozier (1993). The thermal cycling parameters for Cytb and COI basically followed the protocols established by Crozier and Crozier (1993) and Sameshima et al. (1999), including $95^{\circ} \mathrm{C}$ for $5 \mathrm{~min}$ for initial denaturation, 35 cycles of dissociation $\left(92^{\circ} \mathrm{C}, 1\right.$ min), annealing $\left(50^{\circ} \mathrm{C}\right.$ for $\mathrm{Cytb}$ and $54^{\circ} \mathrm{C}$ for $\left.\mathrm{COI}, 1 \mathrm{~min}\right)$, and extension $\left(70^{\circ} \mathrm{C}, 2 \mathrm{~min}\right)$. Illustra ExoProStar was followed according to the instruction of the manufacturer GE Healthcare. For cycle sequencing, ABI PRISM Big Dye Terminator v3.1 cycle sequencing kits from Applied Biosystems were used in an automated sequencer. Sequencing reactions were performed by using ABI 3100 Avant DNA Sequencer (Applied Biosystems).

\section{Phylogenetic inference}

For the phylogenetic analysis of $O$. smaragdina populations, combination of mitochondrial cytochorome b and cytochorome oxidase subunit-1 gene of $1143 \mathrm{bp}$ were used in the analysis. Of which, 63 samples for Cytb and 72 samples for COI genes have been used with 504 bp and 639 bp, respectively. In addition, sequence data of both COI and Cytb were used from Azuma et al. (2002), Azuma et al. (2006) and Asaka (2010). The sequence data of both COI and Cytb of Oecophylla longinoda from Cameroon were used as outgroup in this analysis. The sequencing alignment was done by using Vector NTI Advance ver. 11.5 software. The sequences of Cytb and COI were aligned by using MEGA 6.0 software (Tamura et al. 2013). Phylogenetic trees were inferred from 106 concatenated matrix sequences of both COI and Cytb genes, conducted by MrBayes 3.1.2 (Nascimento et al. 2017; Ronquist and Huelsenbeck, 2003) with 1,000,000 generations (Felsenstein, 1981). For the selection of bestfit model, MrModeltest 2.3 was performed with PAUP*4.0b10. (Nylander, 2004; Posada and Crandall, 1998). The substitution model, GTR + I + G was used in mitochondrial COI and Cytb 
genes were used the alignment was partitioned into 1st, 2nd and 3rd nucleotide positions. The nucleotide sequences for both Cytb and COI were deposited in the GenBank with accession number are corresponding to Appendix 1.

\subsubsection{Results and discussions}

\section{Bayesian phylogenetic tree inferences}

Among identified 197 variable characters, 133 were parsimony informative. The Bayesian analysis of the mitochondrial concatenated matrix dataset of $1143 \mathrm{bp}$ showed that the Bangladeshi O. smaragdina samples were nested into two distinct clades (posterior probability

$>90 \%$ ) (Fig. 4.1). Bangladeshi 48 weaver ant samples were nested with Indian clade of $O$. smaragdina, whereas 39 samples were nested with the Southeast Asian clades. Therefore, the occurrence of both the Indian and SE Asian types was found within Bangladesh. Based on the phylogenetic tree obtained, the Bangladeshi populations showed the overlapping distribution of the Indian and SE Asian types of O. smaragdina (Fig. 4.1). 


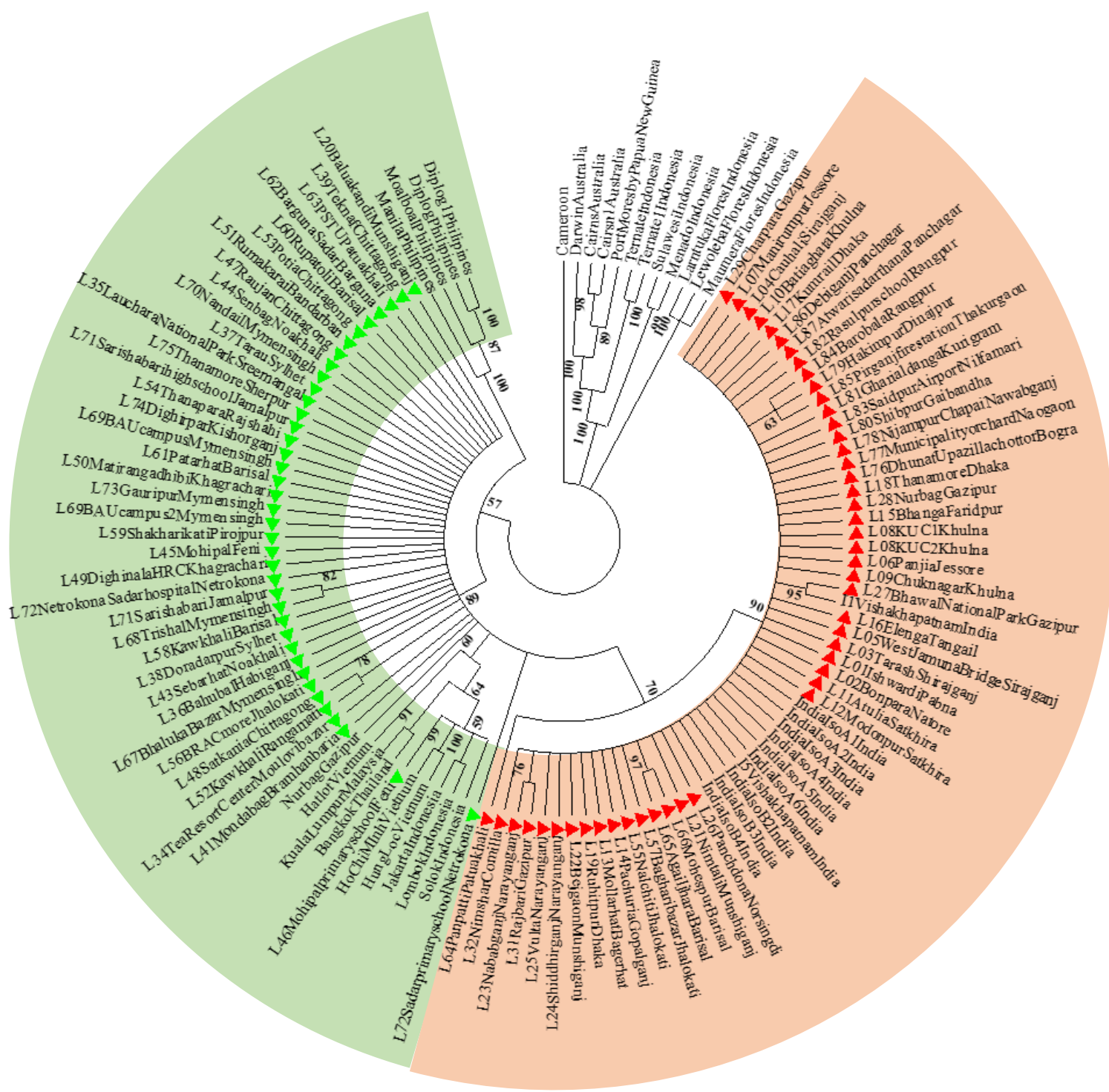

Fig. 4.1 Bayesian phylogenetic tree of Bangladeshi O. smaragdina populations as inferred from the mitochondrial gene fragments (1143bp) of the COI (639 bp) and the Cytb (504 bp) genes (substitution model: GTR + I + G 1000000 generations used in MrBayes 3.1.2 MrModeltest 2.3,PAUP*4.0b10). Number adjacent to internal nodes represent bootstrap values $(\%)$. Green rectangle indicates the samples from Bangladesh in the present study. Additional DNA sequence data were downloaded from DDBJ GenBank. The number ahead of each locality indicates the locality number. Red and green triangle denotes the samples from Bangladesh clustering with Indian and SE Asian types, respectively. Two shaded color represents the two types of Oecophylla population in Bangladesh. 


\section{Summary of the distribution pattern}

The western part of Bangladesh was mainly occupied by Indian types, the Eastern part was dominated by SE Asian types, while, the mixture of two clades was found in the central parts of Bangladesh. (Fig. 4.2). The detailed samples results based on type are showed in Table 4.1. Out of 87 localities, we failed to detect 3 locality types of Oecophylla. The samples from rest 47 localities were identified as Indian type and 37 locality samples as SE Asian types (Table 4.1). According to those results, Bangladesh can be considered as a transitional zone of both the two clades. Divergence time of the ant genus Oecophylla is thought to be a significant factor of such distribution. Diversification within groups in this continent was recorded from the Middle Pliocene to Early Pleistocene (Azuma et al. 2002). After this period, world has encountered a significant climatic change.

It might also affect the distribution of Oecophylla in different parts of the world. Lokkers (1986) suggested two limiting factors, low temperature and humidity for distribution range of Oecophylla in Australia. During Last Glacial Maximum (LGM), the tropic region shifted southward and it retained northward after glaciation. The present study suggested that the Indian and Southeast Asian clades of $O$. smaragdina expanded their distribution northward along suitable regions with high temperature and humidity, and then the two types supposedly encountered and overlapped in central Bangladesh. 
Table. 4.1 Detailed summary of the distribution pattern of weaver ant in Bangladesh

\begin{tabular}{ccccccc}
\hline $\begin{array}{c}\text { Sampled } \\
\text { area }\end{array}$ & $\begin{array}{c}\text { Surveyed } \\
\text { district }\end{array}$ & $\begin{array}{c}\text { Sampled } \\
\text { colonies }\end{array}$ & $\begin{array}{c}\text { Sampled } \\
\text { localities }\end{array}$ & \multicolumn{2}{c}{ Type (in locality) } & Failed \\
\cline { 1 - 1 } & 14 & 18 & 18 & 17 & 1 & \\
Area 01 & 11 & 23 & 22 & 15 & 7 & \\
Area 02 & 10 & 30 & 25 & 13 & 11 & 1 \\
Area 03 & 7 & 15 & 13 & 2 & 10 & 1 \\
Area 04 & 5 & 9 & 9 & 0 & 8 & 1 \\
Area 05 & 47 & 95 & 87 & 47 & 37 & 3 \\
\hline Total & & & & & & \\
\hline
\end{tabular}




\section{Distribution pattern inferred by mtDNA}

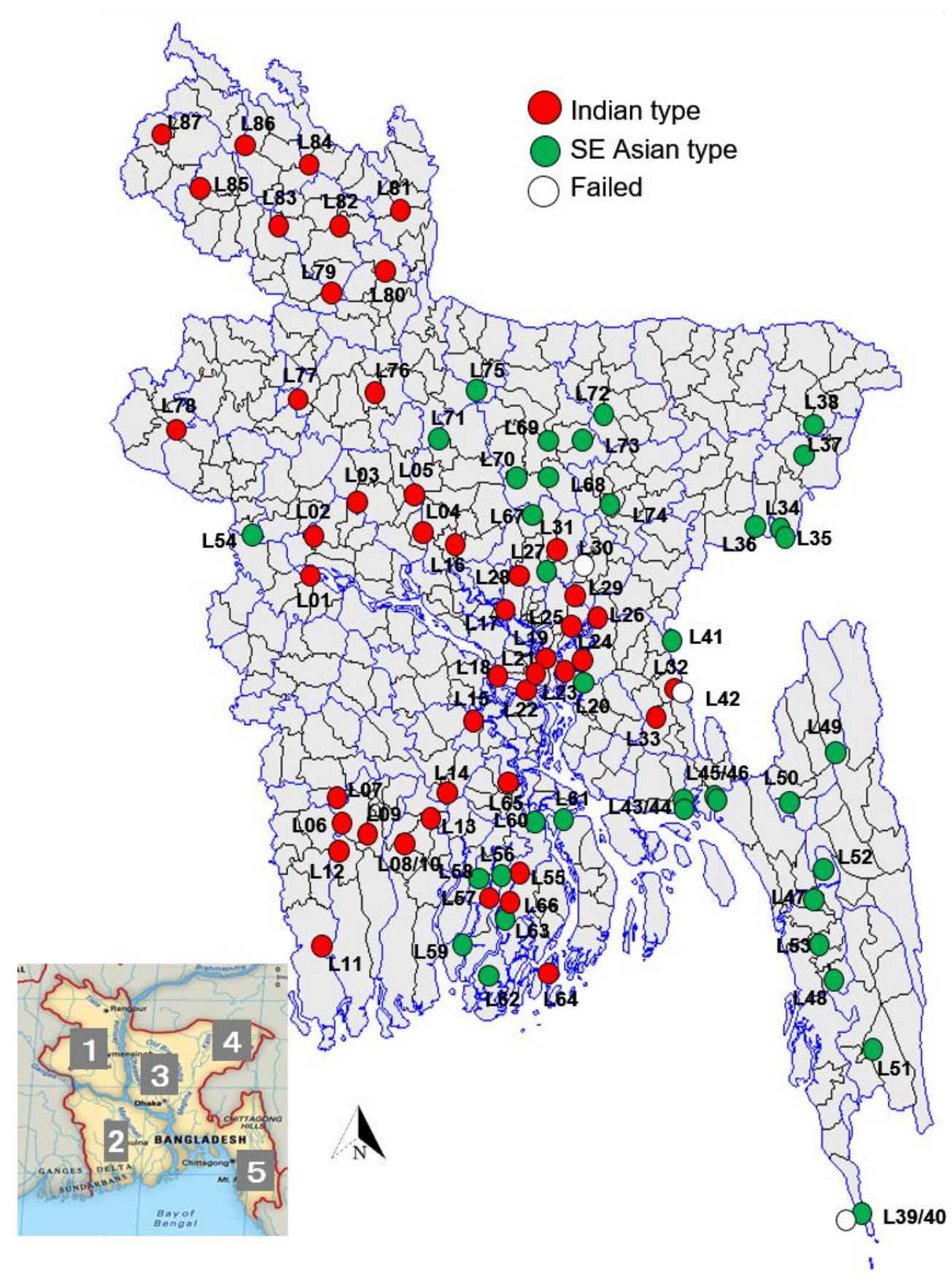

Fig. 4.2 Distribution pattern of Indian and SE Asian types of O. smaragdina in Bangladesh. 


\subsection{Haplotypes and its network distribution of $O$. smaragdina in}

\section{Bangladesh}

\subsubsection{Introduction}

Due to widespread distribution and evolutionary history, $O$. smaragdina was considered to be a valuable material for biogeographic study in tropical Asia. Azuma et al. (2006) proposed an outline of the phylogeography of $O$. smaragdina and they revealed the identity of Oecophylla population of Bangladesh as South East Asian type that distinct from the Indian types by means of mitochondrial DNA analysis of COI and Cytb genes. Similar findings were observed from Asaka (2010) who found a large genetic gap of Oecophylla populations from Bangladesh from India and Sri Lanka where Indian population originated from the Indian refuge and Bangladesh population originated from the Indochina refuge. However, Rahman et al. (2017b) in their phylogeographic study based on mitochondrial Cytb and COI genes, identified the western Bangladeshi population of Oecophylla as Indian type. Based on this interesting result, a details comprehensive phylogeographic study including eastern, northern and central part of Bangladesh were conducted by Rahman et al., (2017a). They identified that the western Bangladesh population were mainly Indian type whereas the Eastern part was dominated by South East Asian type, although the middle part of the country were occupied by overlapping populations of both Indian and South East Asian type. Climatic oscillations during the Pleistocene period have a strong effect on the genetic diversity and distribution of extant species (Hewitt, 2004). Increased aridity and decreased temperatures during the glacial led to a fragmentation of tropical environments and thus influenced the genetic diversity of Oecophylla in these tropics as well. Phylogeographic study with diversified haplotype 
distribution network precisely congregate the genetic diversity phenomena in an particular geographical area.

The purpose of this experiment was to identify the available haplotypes and analyze haplotype network for better understanding the phylogeographic results of $O$. smaragdina in Bangladesh. Our goal was to get insights into the genetic structure and geographical patterns of genetic variation of Oecophylla across much of its distribution based on this haplotype distribution in Bangladesh.

\subsubsection{Materials and methods}

\section{Sampling and preparation of specimens}

The mitochondrial COI genes were extracted from 72 individuals collected from 71 localities of Bangladesh. The localities used in haplotype network analysis are mentioned in Table 3.1 in general methodology chapter.

\section{Molecular data collection}

For the molecular study of haplotype network, we followed the protocol as mentioned in the general methodology in chapter 3 . We have used the mitochondrial COI data for revealing the haplotype network. 


\section{Haplotype network analysis}

For haplotype network analysis of $O$. smaragdina populations, a total 93 sequences have been analyzed including 71 concatenated sequences of COI genes from 67 localities of Bangladesh have been used with 639 bp, In addition, referential sequence data of COI was used from Azuma et al. (2002), Azuma et al. (2006) and Asaka (2010). The sequencing analysis was done by using Vector NTI Advance ver. 11.5 software. The sequences of COI were aligned by using MEGA 6.0 software (Tamura et al. 2013). Haplotype network were determined by using TCS 1.21 software and the network figure has been generated based on TCS results by POP ART- 1.7 (Clement et al. 2000). The nucleotide sequences of COI were deposited in the GenBank with accession number were corresponding to appendix 1.

\subsubsection{Results and discussions}

\section{Oecophylla smaragdina haplotypes in Bangladesh}

Forty-two haplotypes were recorded from 93 concatenated sequences of COI mitochondrial gene of $639 \mathrm{bp}$. The nucleotide diversity was 0.0248709 and a total 89 segregating sites were recorded. The total number of parsimony informative sites was 50 . Seventy two concatenated sequence of COI genes have been used from the samples of Oecophylla in Bangladesh resulted 25 haplotypes. The 25 haplotypes identified from Bangladesh are presented in Fig. 4.3. In this figure, only the variable sites and its position were displayed. 
COHO1 GATCCATAATTAATTAATCTTACCCATTCATGAAATCTGATGAACAA

$\mathrm{COH} 2 \ldots \ldots \ldots \ldots \ldots \ldots \ldots \ldots \ldots \ldots \ldots \ldots \ldots \ldots \ldots$

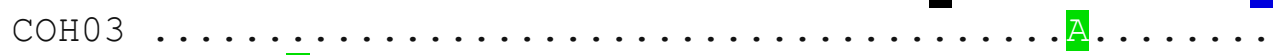

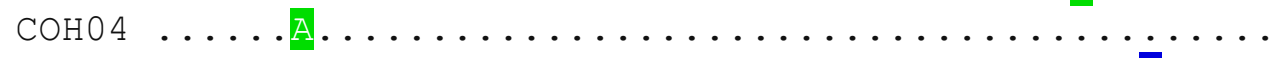

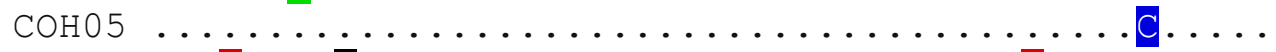

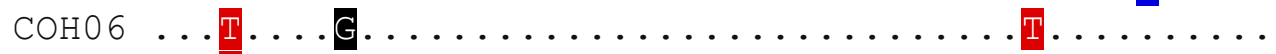

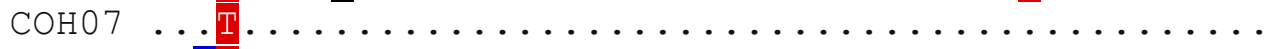

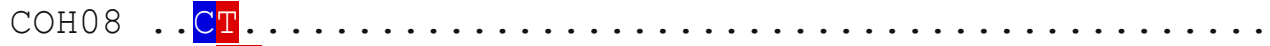

$\mathrm{COHO}$

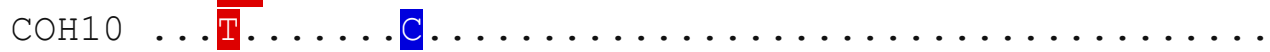

$\mathrm{COH}_{1} 1 \ldots \mathrm{T} \ldots \ldots \ldots \mathrm{C} \ldots \ldots \mathrm{G} \ldots \ldots \ldots \ldots \ldots \ldots$

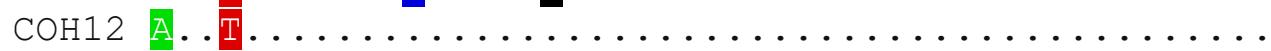

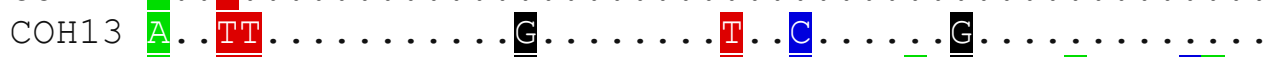

$\mathrm{COH}_{14}$ A. TT.............................А.

COH15 .T.TTT.T.CC.G.C...C.CCAGTTTT.CTTA.G.T.T........

$\mathrm{COH} 16$. T.TTT.T.CC.G.C...C.CCAGTTTT. . TTA.G.T.TC.......

$\mathrm{COH} 17$.T.TTT.T.CC.G.C...C.CCAGTTTT. . TTA.G.T.TC..C.....

$\mathrm{COH} 18$.T.TTT.T.CC.G.C...C.CCAGTTTT.CTTA.G.T.T........ .

$\mathrm{COH} 19 \cdot \mathrm{T} \cdot \mathrm{TTT} \cdot \mathrm{T} \cdot \overline{\mathrm{CC}} \cdot \mathrm{G} \cdot \mathrm{C} \ldots \mathrm{CACCAGTTTT} \cdot \overline{\mathrm{CTTA}} \cdot \mathrm{G} \cdot \mathrm{T} \cdot \mathrm{T} \ldots . . . \mathrm{T} \cdot$.

$\mathrm{COH} 2 \mathrm{O}$

$\mathrm{COH} 21$

$\mathrm{COH} 22$

$\mathrm{COH} 23$

$\mathrm{COH} 24$

$\mathrm{COH} 25$

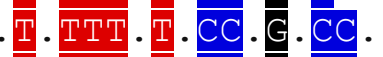

T.TTT.T.CC.G. CC.

. CCAGTTTT

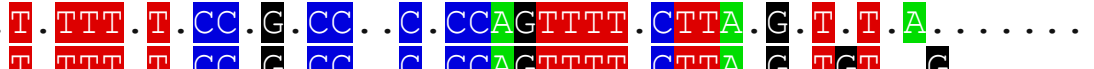

T.TTT.T.CC.G.CC. . C.CCAGTTTT.CTTA.G.TGT. . G.

-T.TTT.T.CC.G.CC. C. CCAGTTTT. CTTA.G.T.T.A.....AC.

.T.TTT.T.CC.G.C...C.CCAGTTTT.CTTA.G.T.T.A...G.AC.

. T. TTTCT.CC.GGC...C.CCAGTTTT. . TTA.G.T.T........

Fig. 4.3 Twenty five haplotypes in Bangladesh and their variable sites with changed position.

The upper three numeric lines denotes the position on longitudinal basis of the each sequence. Each dot represent the identical sequence. 


\section{Haplotype network study}

Bangladeshi haplotypes were marked from $\mathrm{COH} 01$ to $\mathrm{COH} 25$. $\mathrm{COH} 26$ to $\mathrm{COH} 27$ are considered as Indian type, $\mathrm{COH} 28$ to $\mathrm{COH} 35$ are from Indonesia, $\mathrm{COH} 36$ to $\mathrm{COH} 38$ from Philippines, $\mathrm{COH} 39$ to $\mathrm{COH} 40$ from Vietnam, $\mathrm{COH} 41$ from Malaysia and $\mathrm{COH} 42$ from Thailand (Fig.4.4). The detailed haplotype list were presented in Table 4.2. Bangladeshi haplotypes were clustered into two distinct zone on the network tree. Haplotype COH01 to $\mathrm{COH} 13$ were closely associated with the haplotypes from the Panjab state of India with $\mathrm{COH} 26$ and $\mathrm{COH} 27$. Moreover, $\mathrm{COH} 10$ and $\mathrm{COH} 12$ includes the haplotypes from Indian isolates along with the Bangladeshi haplotypes. On the other hand the Bangladeshi haplotypes from $\mathrm{COH} 14$ to $\mathrm{COH} 25$ are found to be clustered with the haplotypes associated from SE Asian clades. They were well connected with the haplotypes from Indonesia and Vietnam. Like other ant species, Oecophylla smaragdina were profoundly influenced by Pleistocene glaciation. This also happened in this South Asian continent. 


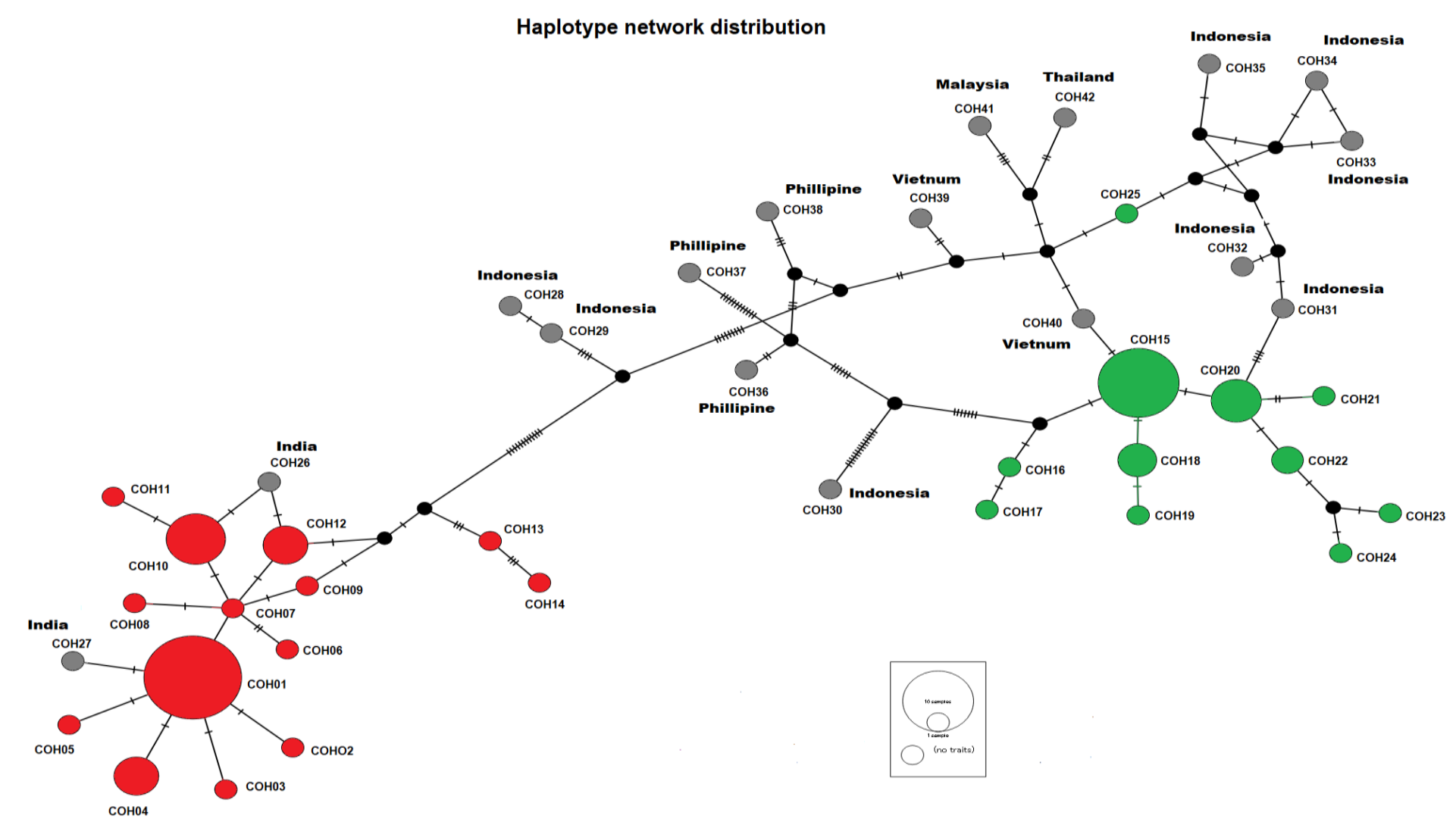

Fig. 4.4 Haplotype network of $O$. smaragdina. Solid colored circles indicate individual haplotype. A single bar connecting two haplotypes corresponds to a single base pair mutation. Each hatch mark on the bar indicate single base pair mutations. Haplotypes belonging to Indian clades are separated from the SE Asian clades by one of the largest number of mutational steps (27) inferred in the network. The locality information corresponding to each haplotype are represented in table 4.2. 
Table 4.2 List of haplotypes inferred from COI gene sequences

\begin{tabular}{|c|c|c|}
\hline SI No. & Haplotype No. & Corresponding locality (Country) \\
\hline 1 & $\mathrm{COH} 01$ & $\begin{array}{l}\text { L01, L02, L05, L07, L09, L10, L11, L14, L15, , L55, L57 } \\
\text { L76, L77, L78, L80, L81, L83, L86, L87 (Bangladesh) }\end{array}$ \\
\hline 2 & $\mathrm{COH} 02$ & L64 (Bangladesh) \\
\hline 3 & $\mathrm{COH} 03$ & L04 (Bangladesh) \\
\hline 4 & $\mathrm{COH} 04$ & L18, L21, L26, L32 (Bangladesh) \\
\hline 5 & $\mathrm{COH} 05$ & L82 (Bangladesh) \\
\hline 6 & $\mathrm{COHO6}$ & L27 (Bangladesh) \\
\hline 7 & $\mathrm{COH} 07$ & L16 (Bangladesh) \\
\hline 8 & $\mathrm{COH} 08$ & L29 (Bangladesh) \\
\hline 9 & COHO9 & L12 \\
\hline 10 & $\mathrm{COH} 10$ & L08, L08 (02), L03, L79, L84 (Bangladesh) ISOA2 (India) \\
\hline 11 & $\mathrm{COH} 11$ & L28 \\
\hline 12 & $\mathrm{COH} 12$ & L06 (Bangladesh), ISOA3, ISOA4, ISOA5 (India) \\
\hline 13 & $\mathrm{COH} 13$ & L65 (Bangladesh) \\
\hline 14 & $\mathrm{COH} 14$ & L66 (Bangladesh) \\
\hline 15 & $\mathrm{COH} 15$ & $\begin{array}{l}\text { Nurbag, L34, L67, L36, L43, L38, L45, L73, L50, L69, } \\
\text { L74, L75, L35 (Bangladesh) }\end{array}$ \\
\hline 16 & $\mathrm{COH} 16$ & L52 (Bangladesh) \\
\hline 17 & $\mathrm{COH} 17$ & L48, L39 (Bangladesh) \\
\hline 18 & $\mathrm{COH} 18$ & L58, L59, L61 (Bangladesh) \\
\hline 19 & $\mathrm{COH} 19$ & L54 (Bangladesh) \\
\hline 20 & $\mathrm{COH} 20$ & L72 (2), L72, L41, L49, L37 (Bangladesh) \\
\hline 21 & $\mathrm{COH} 21$ & L69(2), L71(2) (Bangladesh) \\
\hline 22 & $\mathrm{COH} 22$ & L56 (Bangladesh) \\
\hline 23 & $\mathrm{COH} 23$ & L71 (Bangladesh) \\
\hline 24 & $\mathrm{COH} 24$ & L68 (Bangladesh) \\
\hline 25 & $\mathrm{COH} 25$ & L46(Bangladesh) \\
\hline 26 & $\mathrm{COH} 26$ & ISOA6 (India) \\
\hline 27 & $\mathrm{COH} 27$ & ISOA1 (India) \\
\hline 28 & $\mathrm{COH} 28$ & Larantuka (Indonesia) \\
\hline 29 & $\mathrm{COH} 29$ & Lewleba (Indonesia) \\
\hline 30 & $\mathrm{COH} 30$ & Sulawesi (Indonesia) \\
\hline 31 & $\mathrm{COH} 31$ & Bogor (Indonesia) \\
\hline 32 & $\mathrm{COH} 32$ & Bali (Indonesia) \\
\hline 33 & $\mathrm{COH} 33$ & Rakata (Indonesia) \\
\hline 34 & $\mathrm{COH} 34$ & Jakarta (Indonesia) \\
\hline 35 & $\mathrm{COH} 35$ & Lombok (Philippine) \\
\hline 36 & $\mathrm{COH} 36$ & Manilla (Philippine) \\
\hline 37 & $\mathrm{COH} 37$ & Diplog (Philippine) \\
\hline 38 & $\mathrm{COH} 38$ & Moalboal (Philippine) \\
\hline 39 & $\mathrm{COH} 39$ & Hunloc (Vietnam) \\
\hline 40 & $\mathrm{COH} 40$ & Hatlot (Vietnam) \\
\hline 41 & $\mathrm{COH} 41$ & Kualalumpur (Malaysia) \\
\hline 42 & $\mathrm{COH} 42$ & Bangkok (Thailand) \\
\hline
\end{tabular}


The haplotype network showed a clear distribution of Indian and SE Asian haplotypes in Bangladesh. This shape of network seems bottleneck-type. The two types (groups) are connected with many missing haplotypes (longer branch); it is suggesting survived populations remained in refugia. Star-like subnetworks suggest recent expansion of populations. In the geographical distribution suggested that the western haplotypes are relatively less diverse and is connected mainly with the Indian haplotypes while the haplotypes from eastern part showed more genetic diversification.

Vidya et al. (2009) have found the similar results in their phylogeographic study of distribution of Asian elephants. This sorts of haplotype network distribution revealed that there was no effective barrier of separating Indian and SE Asian haplotypes in Bangladesh, hence Bangladesh is considered as a transitional zone of genetic diversification of Oecophylla populations. In the previous phylogeographic study by Azuma et al. (2002, 2006), the diversification of Oecophylla occurred during Pleistocene in this continent and the effects of last glacial maximum (LGM) might have an influential phenomenon of such distribution. This can be supported by the findings of Seal et al. (2015) who mentioned in their phylogeography of two Trachymyrmex species along the south eastern coastal plain of North America and characterized the both species by reduced haplotypic variation that may indicate recent expansion and / or bottleneck associated with changed climatic condition. 


\section{CHAPTER 5}

DIVERGENCE AND CONTACT OF INDIAN AND SE ASIAN TYPES OF OECOPHYLLA SMARAGDINA IN BANGLADESH 


\section{CHAPTER 5}

\section{Divergence and contact of Indian and SE Asian types of Oecophylla smaragdina in Bangladesh}

\subsection{Divergence time estimation of $O$. smaragdina in Bangladesh}

\subsubsection{Introduction}

Oecophylla smaragdina, based on the fossil record might have originated in the early Paleogene (ca. $60 \mathrm{Ma}$ ) in the Palaearctic region, and dispersed during the climatic changes of the Eocene-Oligocene transition at ca. 43 Ma (Dlussky et al. 2008). The abrupt cooling during this period had great impacts on biodiversity (Katz et al. 2008). During this period, Earth's climate shifted from a relatively ice-free world to one with glacial conditions in polar regions characterized by substantial ice sheets (Bowen, 2007). Recently, Blamier et al. (2015) estimated the divergence time of the genus Oecophylla based on the fossil records and ultra conserved elements (UCEs). They estimated that Oecophylla crown group evolved during Oligocene at ca. < $30 \mathrm{Ma}$ and stem-group evolved during early Eocene at ca.50 Ma. Wetterer (2017) gave a glimpse of distribution of $O$. smaragdina in this continent with some interesting evidence of distribution. Oecophylla smaragdina and $O$. longinoda have diverged in 13.3 to 11.3Ma ago, in the late Miocene. Diversification of seven groups occurred between the middle of Miocene to early Pliocene. While the diversification within groups was recorded between middle Pliocene to early Pleistocene (Azuma et al. 2006). There was no evidence regarding the divergence time of group 1 or Indian types. Due to widespread distribution, $O$. smaragdina 
was considered valuable materials for biogeographic study in tropical Asia. In the same period of Eocene-Oligocene transition, the emergence of South-East (SE) Asia, caused by the collision of the Eurasian and Australian plates (Buerki et al. 2011), already formed a large emergent land area by the late Cretaceous (including, for example, the older parts of Malaysia and Southwest Borneo), were created from this period onwards, with a peak of tectonic activity during the Miocene (Hall, 2009). Azuma et al. (2006) estimated the divergence time of Oecophylla smaragdina. Based on that estimation, O. smaragdina and $O$. longinoda diverged 13.3- 11.3 Ma, in the late Miocene. Diversification within the seven groups have been estimated between 7.8 and 3.6 Ma (Fig. 5.1). As Bangladesh has the overlapping populations of $O$. smaragdina from group 1 and group 2, so, the estimation of the divergence history of that two types would be an important biogeographical evidence of divergence history. The purpose of this study is to get insights of the estimation of the time of divergence of Indian and SE Asian haplotypes in Bangladesh.

\subsubsection{Materials and methods}

In this analysis, a total of seven localities nucleotide sequence data of Cytochrome oxidase subunit 1 (COI) and Cytb data were used. Those seven localities includes L07, L08, L26, L32, L41, L49, L66, respectively. The detailed locality information are presented in Table 3.1. in the general methodology chapter. The sequencing techniques were described in the general methodology chapter. In addition, in this analysis, sequence data of both COI and Cytb were used from Azuma et al. (2002), Azuma et al. (2006) and Asaka (2010) retrieved from DDBJ GenBank. Sequence data of both COI and Cytb of Oecophylla longinoda from Cameroon were used as outgroup in this analysis. The sequencing analysis was done by using Vector NTI Advance ver. 11.5 software. Haplotypes of Cytb and COI were aligned by using MEGA 6.0 
software (Tamura et al. 2013). Out of these seven localities, five localities were Indian type and two localities were of SE Asian type, inferred by both mitochondrial and nuclear DNA analysis. A total of 1149 bp of COI and Cytb nucleotide sequences of the samples collected from those 7 localities were used along with the samples from Malaysian and Cameroon as references. A Bayesian Markov chain Monte Carlo (MCMC) packages (Drummond et al. 2006), which relay on a relaxed molecular clock approach, were used to estimate the divergence time. Optimal nucleotide substitutional model were chosen by Mr. ModelTest.

\subsubsection{Results and discussion}

The results of divergence time are shown in Fig. 5.2 in the MCMC divergence tree. In this tree, sequences of the haplotypes from Cameroon is considered as outgroup, and Malaysian and Indian haplotypes were used as reference. Although these divergence tree is not showing quite a good resolution due to lack of so many resolved sister groups but we can get some interesting evidence. 


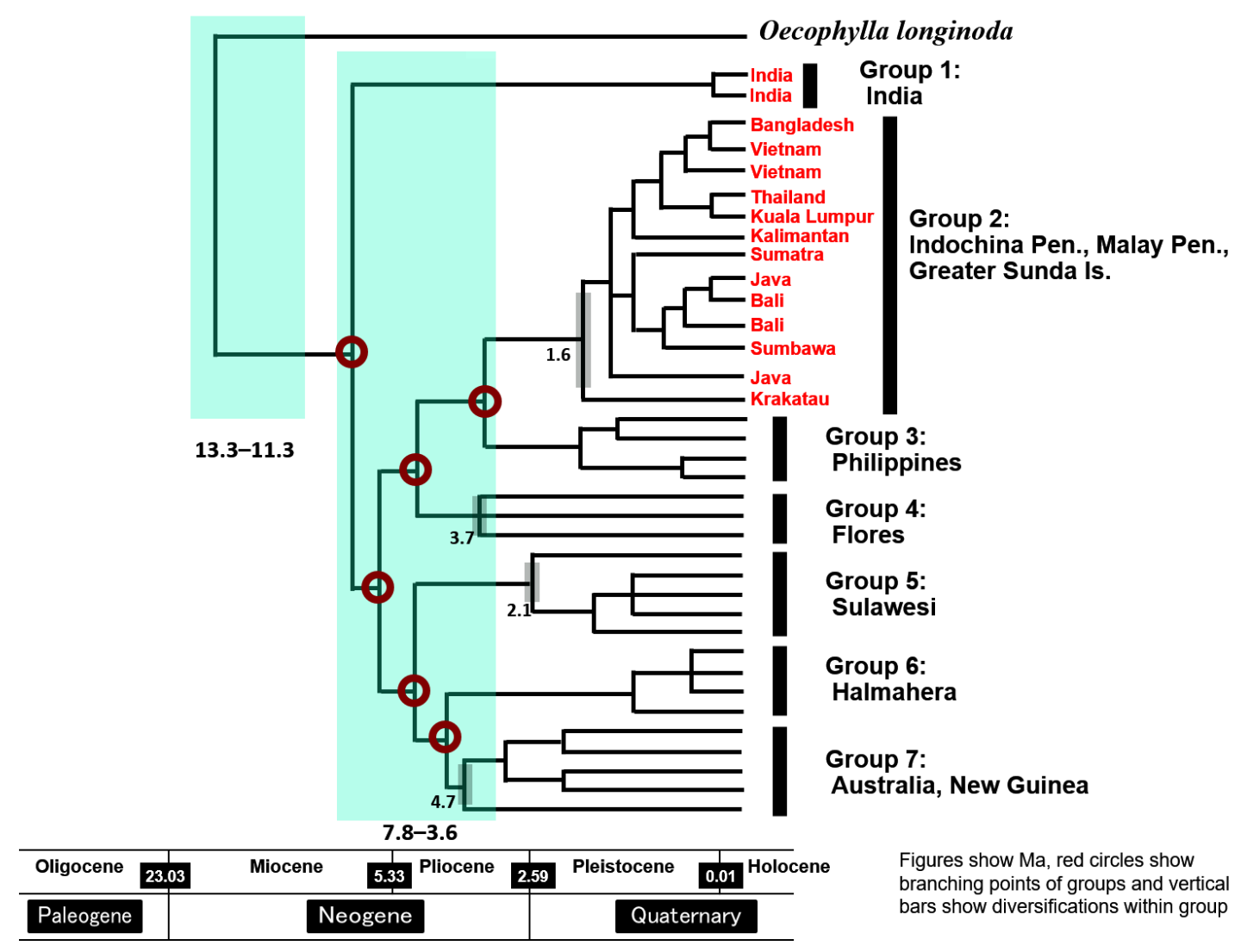

Fig. 5.1 Divergence time of Oecophylla smaragdina modified from Azuma et al. (2006). The red text of the area indicating the Indian and SE Asian group of Oecophylla calculated by Azuma et al. (2006). 
According to this divergence tree, Indian type diverged ca. 2.2 Ma and SE Asian type diverged ca. 0.20 Ma corresponding to early to late Pleistocene. From this tree, we get the information regarding the divergence time of the Indian type that was missing in the previous study by Azuma et al. (2006). The quaternary paleo-geographic history of the SE Asia during the ice age showed some significant evidence of the divergence pattern. Vidya et al. (2009) discussed the distribution of the two clades of Asian elephants and proved the effect of allopatrically in different glacial refugia, the alpha clade in the Myanmar region and the beta clade possibly in southern India-Sri Lanka, 1.6-2.1 Ma ago. Results from nested clade and dispersal-vicariance analyses indicate a subsequent isolation and independent diversification of the $b$ clade in both Sri Lanka and the Sunda region, followed by northward expansion of the clade.

Pleistocene glaciation has significant influential effects on temperature and rainfall that favored the diversification of several ant species including Oecophylla distribution (Lokkers, 1986). Rainfall moderate the vegetation density while low temperature inhibiting larval development. As Pleistocene glaciation had the effect on both these two limiting factors of $O$. smaragdina distribution so the divergence resulted (Lokkers, 1986). 


\section{Divergence time of Indian and SE Asian types in Bangladesh}

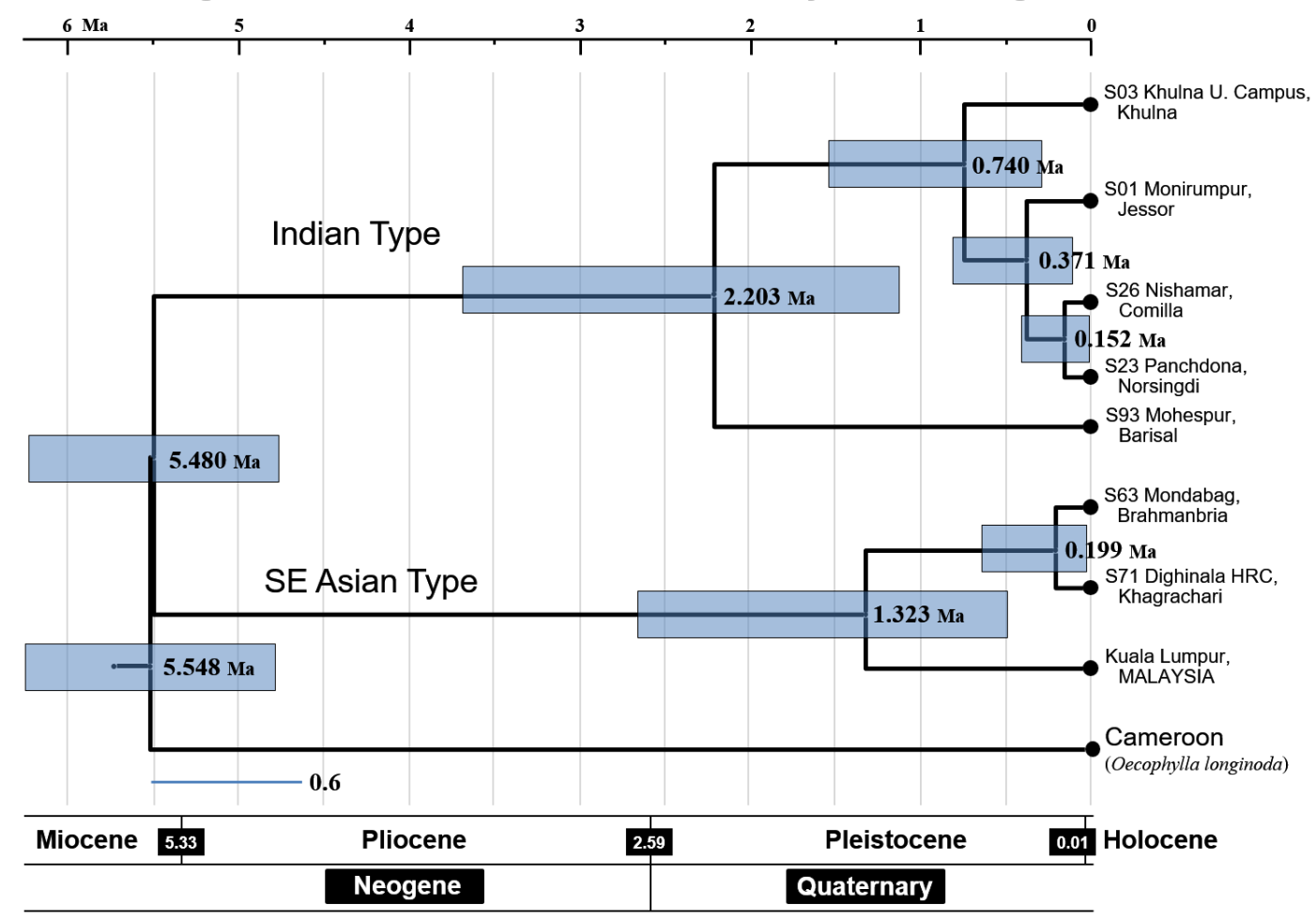

Fig. 5.2 Divergence time of Indian and SE Asian types of O. smaragdina in Bangladesh. 
Bangladesh's geology began 350 million years ago when the Pangean supercontinent broke apart (Mannan, 2002). The Bengal Basin began 127 million years ago when the Indian Plate rifted away from Antarctica at $18 \mathrm{~cm}$ per year for 20 million years. Basin began 127 million years ago when the Indian Plate rifted away from Antarctica at $18 \mathrm{~cm}$ per year for 20 million years. This rapid velocity stopped 55 million years ago and was followed by a period in which little or no spreading took place west of the ninety East ridge for 20 million years. Formation of Himalaya due to continental collision with the following figures (Aitchison et al. 2008). The Indian subcontinent lies atop the Indian tectonic plate, a minor plate within the Indo-Australian Plate (Ali, 2005).Its defining geological processes began a north eastwards drift lasting fifty million years across the then unformed Indian Ocean. The subcontinent's subsequent collision with the Eurasian Plate and subduction under it, gave rise to the Himalayas, the planet's highest mountains (Aitchison et al. 2008). In the former seabed immediately south of the emerging Himalayas, plate movement created a vast trough, which, having gradually been filled with sediment borne by the Indus and its tributaries and the Ganges and its tributaries, now forms the Indo-Gangetic Plain (Uddin and Lundberg, 1999).

According to our study, diversification of both the types occurred in Pleistocene. There is a rapid fluctuation of temperature from late Pliocene to Pleistocene. It might influenced the distribution of Oecophylla in different part of the world. During that time, fragmentation and expansion of Oecophylla population happened. During LGM, the tropic changed from North to southward and it retained to north after glaciation. Thus, Bangladesh become vacant after glaciation with the tropical climate and hence the occurrence of the both the types have been found subsequently. 


\subsection{Hybridization scenario of Indian and SE Asian types of weaver ant using long wavelength rhodopsin $(\mathrm{LW} R \mathrm{R})$ and microsatellite markers}

\subsubsection{Introduction}

Previous phylogeographic study on O. smaragdina based on mitochondrial Cytb and CO1 genes identified two major types where Indian types occurred mainly in India and Sri Lanka while the Southeast Asian (SE Asian) types have been observed in most of the SE Asian countries including Bangladesh (Azuma et al. 2006). However, recent phylogenetic study revealed the occurrence and dominancy of Indian type in the western part (Rahman et al. 2017b) and SE Asian types in the eastern part and overlapping population of O. smaragdina at the central part of Bangladesh (Rahman et al. 2017a). In Bangladesh, the occurrence of different types implies the chance of hybridization. Recently, for inferring the evidence of hybridization a comprehensive view of evolutionary history by analyzing nuclear and mitochondrial DNA was found effective and has been using extensively (Roos et al. 2011). The nuclear long-wavelength rhodopsin gene (LW $R h$ ) belongs to a family of visual pigment genes and has been regarded as a useful marker for the between-species level phylogeny of insects, especially Hymenoptera (Ascher et al. 2001; Cameron and Williams, 2003). In the LW $R h$ analysis, Azuma et al. (2006) categorized the Indian and SE Asian type of O. smaragdina population as Smaragdina B and Smaragdina A by comparing the nucleotide sequences. This analysis suggested that SE Asian are derived and monophyletic while the Indian type is the ancestral. Discordant genetic relationships between mtDNA and nuclear DNA results from mitochondrial introgression or the incomplete lineage sorting (Eto et al. 2013). Therefore, for confirming the validity of phylogenetic study LW $R h$ nuclear DNA sequence of $O$. smaragdina 
colonies from some randomly selected localities in Bangladesh need to be compared with the results of mtDNA sequences.

In the recent time, the 'microsatellite' markers, also known as simple sequence repeats (SSRs) are considered as the codominant as it identifies the polymorphism along with detection of the high level of heterozygosity and has high mutation rate (Loxdale and Lushai, 1998; Hancock, 1999). The microsatellite markers consist of short but repeated units of around two to six base pairs in length and including both coding and non-coding regions can be up to 200 bp (Beukeboom and Zwaan, 2005). By combining the alleles from each parental species in all loci, microsatellites can indicate F1 hybrids as microsatellite is considered as nuclear DNA markers, although the event of backcrossing has the significant effect for detecting hybridization (Goodman et al. 1999). Through mtDNA the maternal identity of the species might be possible as mtDNA is maternally inherited, but mtDNA cannot solely detect hybridization. Hybridization can be revealed through the inconsistency result of mt DNA and nuclear DNA analysis when back crossing with the parental species occures. However by only microsatellite study, hybridization can be undetected if backcrossing occurred repeatedly because back crossing sometimes causes the complete elimination of the nuclear genome of the maternal species from hybrid (Steiner et al. 2011).

Mallet (2005) reported that hybridization often take place among the closely related species because of insufficient evolvement of reproductive barriers. In that sense there was a great chance of occurring hybrid that needed to be trace out. This may lead the inconsistency between nDNA and mtDNA types within the cell of a hybrid.

The main objectives of this study were to analyze the nuclear LW $R h$ gene for detecting possible hybridization by pointing out the inconsistency of nucleotide sequences. The occurrence of both Indian and SE Asia types, created the possibility of a hybrid colony of $O$. 
smaragdina, especially in the overlapping zone in Bangladesh. In the present context, there are four possible combinations can happened within the cell if the crossing between the male and female of Indian and SE Asian type occurred. The occurrence of either Indian or SE Asian in both mtDNA and nDNA is consistent, i.e., both the mtDNA and nDNA are Indian type or both are the SE Asian type. The inconsistency might be find out if the nDNA are Indian type and mtDNA are SE Asian type or the vice-versa (Fig. 5.3a). In the case, where mtDNA are SE Asian type, the crossing might to be expected between the male of Indian type and female of SE Asian type and mtDNA are maternally inherited. Through, comparing the results of the nucleotide sequences obtained from nDNA analysis by LW $R h$ and mtDNA and nDNA and if there any inconsistency was observed, it can partially reveals the hybrid phenomenon but cannot fully detect the hybridization status of the colony. In addition, in the diploid cell, the nucleus can contain both the Indian and SE Asian types. The mtDNA types of that cell with both Indian and SE Asian types will detect the crossing pattern either the male or female are of Indian or SE Asian type as shown in Fig. 5.3b. Microsatellite markers could identify the heterozygosity in the above-mentioned condition. The detailed explanation about the justification of choosing nuclear DNA and microsatellite analysis for revealing the hybridization status were described in Fig. 5.3. Therefore, the another purpose of this study was to facilitate further confirmation of heterozygosity along with the actual hybrid condition within the diploid nucleus by detecting identical allele between Indian and SE Asian type within the colony. 
Tracing the evidence of hybridization

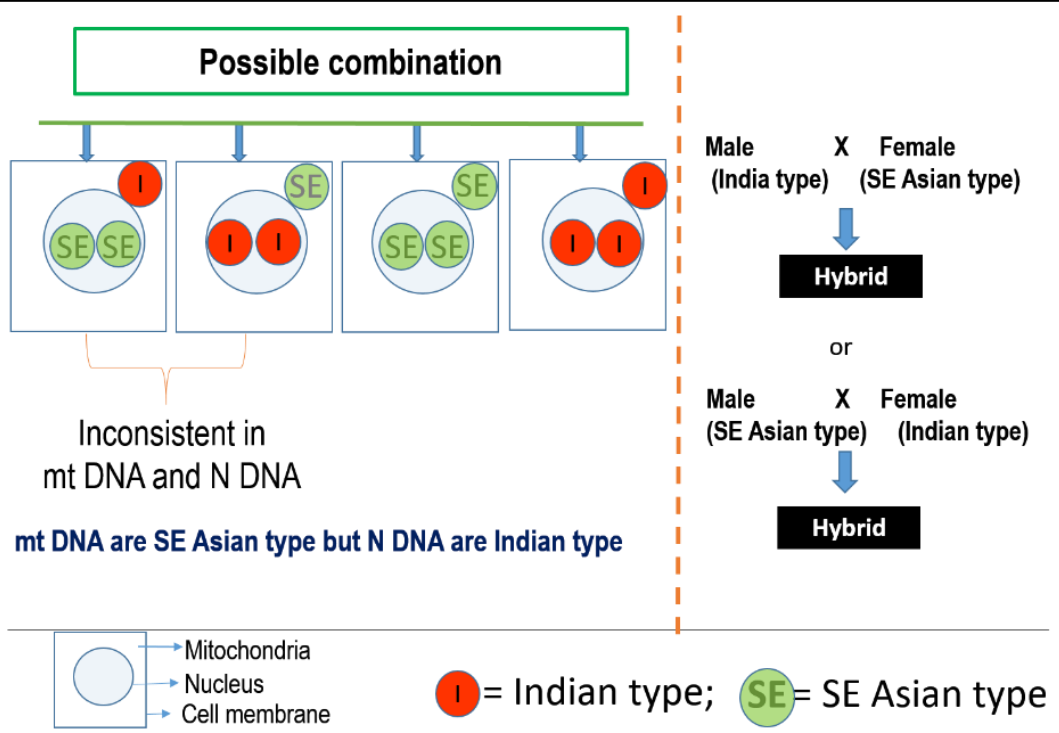

Fig. 5.3a. Consistent and inconsistent status of mitochondrial and nuclear DNA in cell

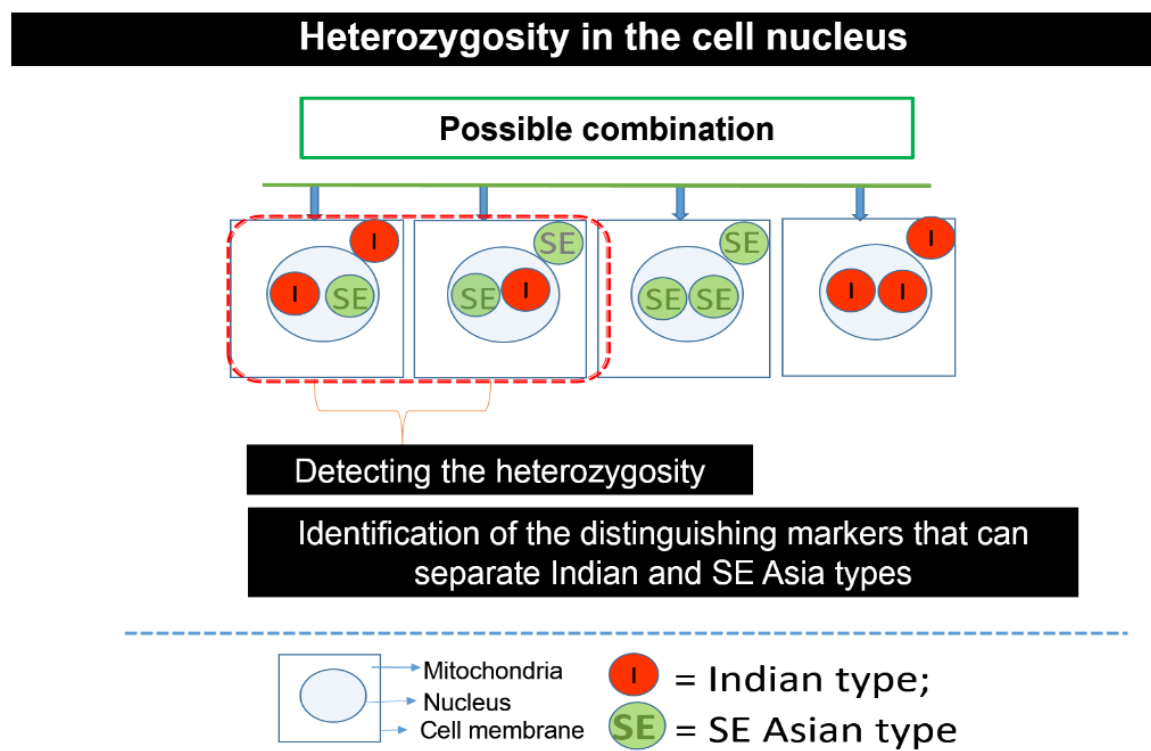

Fig. 5.3b. Heterozygous status of the cell nucleus

Fig. 5.3 mtDNA and nDNA inconsistency pattern and the heterozygous status within the cell due to crossing of male and female of different Indian and SE Asian types. 


\subsubsection{Materials and methods}

\section{LW $R h$ analysis}

Adult Oecophylla smaragdina workers from 40 colonies of 39 localities of Bangladesh were used for performing this study in 2013 to 2017. The detailed procedure of nDNA analysis by Long wave length Rhodopsin (LW Rh) were described in the chapter III in the detailed methodology section. The locality information with their corresponding locality code are presented in chapter 3, Table 3.1 .

The sequencing results of Nuclear DNA analysis from 40 samples of 39 localities in Bangladesh have been deposited to GenBank. The locality information with accession number was corresponding to the tables in the general methodology. For finding the inconsistency, the comparison was done between the previously sequenced results of a phylogeographic study by mtDNA analysis (COI and Cytb genes) from (Rahman et al. 2017b) and nuclear DNA among those 39 localities. For the two localities (locality $34 \&$ locality 46), a total of 40 individuals were analyzed and the sequence data was deposited to GenBank. The nucleotide sequences of LW $R h$ by Azuma et al. (2006) were used as references. The intron region was identified by comparing the 528-bp sequence with LW Rh mRNA of the Saharan silver ant (Cataglyphis bombycinus, DDBJ accession no. U32501), carpenter ant (Camponotus abdominalis, U32502), and large earth bumblebee (Bombus terrestris, AF091722). Whereas insect opsin genes comprise many paralogous copies, the determined sequences of Oecophylla were more similar to the three LW Rh sequences than to any others based on a homology search using FASTA in DDBJ. This homology search also proved that the amplified region was LW $R h$. After identifying the intron regions, the introns were removed and the sequences were aligned in MEGA 7.0 


\section{Microsatellite study}

Six Oecophylla smaragdina colonies from 6 localities of Bangladesh had been selected including two inconsistent locality L34 and L46 as detected by nuclear DNA Analysis. The samplings sites for microsatellite study were corresponding to Table 3.1 in the general methodology chapter.

\section{DNA extraction}

For molecular analyses, specimens were randomly chosen from 07 colonies of 07 different localities. 10 individuals from each colony were selected randomly for extraction of DNA. For the convenient discussion, we grouped sample no 133 to 142 from L34, 143 to 152 from L46, 153 to 160 from L27, 163 to 170 from L67, 173 to 180 from L13, 181 to 188 from L50 and 189 to 195 from L66. Genomic DNA was extracted from the fore, middle and hind legs of specimens that were preserved in alcohol by using QIAGEN DNeasy Blood and Tissue kit (Qiagen, Maryland, USA) following manufacturer's instruction. Samples were vortexed by adding $180 \mu 1$ Buffer ATL and $20 \mu 1$ proteinase K. Sample were incubated at $55^{\circ} \mathrm{C}$ for 48 hours. DNA extraction was completed by adding two wash buffer AW1 and wash buffer AW2 and Buffer AE and lysis buffer AL and elusion buffer AE, as per manufacturer instruction. All centrifugation steps were completed at room temperature. The colony mates of the specimens used for DNA analysis were preserved in the laboratory of Institute of Tropical Agriculture, Kyushu University after DNA extraction. 


\section{Microsatellites PCR condition and primer setting objectives}

The primers used in PCR was mentioned in Table 3.5. PCR was performed in a $15 \mu 1$ reaction volume containing $1 \mu \mathrm{l} \times$ reaction buffer (10XEx7Eq buffer), $1 \mu 1 \times \mathrm{dNTP}$ with 1.8 $\mathrm{mM} \mathrm{MgCl} 2,1 \mu \mathrm{l}$ of each primer, $0.1 \mu \mathrm{l}$ of Ex Taq DNA polymerase (TAKARA, USA), and about $1 \mu$ template DNA. Forward primers were 5'-end labeled with a fluorescent dye either 6-FAM.

Cycling conditions were mentioned in table 5.1. Loci and primers used are given in table 5.2. Fragments were run on an ABI PRISM 310 genetic analyzer (Applied Biosystems). For gene mapping by fragment analysis and data processing, Peak Scanner software vr 1.0 (Applied Biosystems) was used.

Table 5.1 PCR parameters used in microsatellite analysis

\begin{tabular}{|c|c|c|c|c|c|}
\hline \multicolumn{6}{|c|}{ PCR for Microsatellite study } \\
\hline Steps & Times $(\mathrm{X})$ & ${ }^{0} \mathrm{C}$ & M:S & Go to & Loops \\
\hline 1 & & 95.0 & 05:00 & & \\
\hline 2 & & 92.0 & $0: 45$ & & \\
\hline 3 & 35 & 48.0 & $0: 45$ & & \\
\hline 4 & & 72.0 & 01:00 & 2 & 34 \\
\hline 5 & & 72.0 & 05:00 & & \\
\hline 6 & & 4.0 & Pause & & \\
\hline
\end{tabular}


Table 5.2 List of loci used in microsatellite analysis of $O$. smaragdina in Bangladesh modified from (Azuma et al. 2004)

\begin{tabular}{|c|c|c|c|c|}
\hline $\begin{array}{l}\text { Locus } \\
\text { Name } \\
\end{array}$ & Primer Sequence $\left(5^{\prime}-3^{\prime}\right)$ & Repeat motif & $\operatorname{Ta}\left({ }^{\circ} \mathrm{C}\right)$ & References \\
\hline MS2.2.2 & $\begin{array}{l}\text { F:GTCTTATGTGTGGCCACTGCGA } \\
\text { R: GTGAAATGAACGTGACTTG }\end{array}$ & (GCA)6 & 48 & \\
\hline MS2.3 & $\begin{array}{l}\text { F: TCCAGGTGACCGTCGTGT } \\
\text { R: CATACACATTCGCGTACG }\end{array}$ & (GT) $5 \mathrm{GC}(\mathrm{GT}) 5$ & 48 & \\
\hline MS2.14 & $\begin{array}{l}\text { F: TCTACGTGTCTAACCCAAC } \\
\text { R:GCGAGTCTACTCCATCGTATAG }\end{array}$ & $\begin{array}{l}\text { (CGA)4CGT(CGA)6CAA- } \\
\text { (CGA)10TGA(CGA)3 }\end{array}$ & 52 & \\
\hline MS3.2 & $\begin{array}{l}\text { F: GTGACATTGTCGGCGA } \\
\text { R: CGAGCGCGAAAATTTCGTC }\end{array}$ & $(\mathrm{GA}) 6$ & 52 & \\
\hline MS5.2 & $\begin{array}{l}\text { F: AATTACAGTTCGGTCTCG } \\
\text { R:ATCGAACTTCGCTTCGGTTGTA }\end{array}$ & (CT)11(CTTT)3GTTT(CTTT)2 & 48 & \\
\hline MS5.10 & $\begin{array}{l}\text { F: GAGAGGAAGTGCACCACAATG } \\
\text { R: CGAACCGTGAGGAAATGTCGA }\end{array}$ & $(\mathrm{GA}) 3 \mathrm{AA}(\mathrm{GA}) 5 \mathrm{~A} 8(\mathrm{GA}) 4$ & 52 & \\
\hline MS6.29 & $\begin{array}{l}\text { F: CAATCCAGTTGCACGGCTA } \\
\text { R: GTAACTTCGAGTTCGC }\end{array}$ & $(\mathrm{GA}) 3 \mathrm{AA}(\mathrm{GA}) 4 \mathrm{~A}(\mathrm{GA}) 3$ & 49 & $\begin{array}{l}\text { Azuma et } \\
\text { al. (2004) }\end{array}$ \\
\hline MS6.45 & $\begin{array}{l}\text { F: GGTCGTTGCTGACCGT } \\
\text { R: CAGATACAGGCAATGCT }\end{array}$ & (GTT)3GCT(GTT)9(GCT)4(GTT)2(GCT)4 & 49 & \\
\hline MS6.47 & $\begin{array}{l}\text { F: AGCCCTCTTGTTCATGA } \\
\text { R: TTAAATTCGGCCGCA }\end{array}$ & $(\mathrm{GA}) 9$ & 45 & \\
\hline MS7.1 & $\begin{array}{l}\text { F: AAAGGACGTTGACGCGAC } \\
\text { R: ACGTGCAATCCATTCACG }\end{array}$ & $(\mathrm{GAT}) 8$ & 52 & \\
\hline MS8.24 & $\begin{array}{l}\text { F: GCAGACAATGGCTATTTGT } \\
\text { R: CGATGTGATTTAGCCGA }\end{array}$ & $\begin{array}{l}(\mathrm{CTT}) 5 \mathrm{TCT}(\mathrm{CTT}) 3- \\
(\mathrm{GA}) 3 \mathrm{AA}(\mathrm{GA}) 11 \mathrm{AATA}(\mathrm{GA}) 9\end{array}$ & 50 & \\
\hline
\end{tabular}




\subsubsection{Results and discussions}

\section{Nuclear DNA study by LW Rh}

Among 39 localities, 27 locality samples were found as Indian type and 12 localities are of SE Asian type (Table 5.3). Between these two types, there was only one substitution: site 27 contains thymine in SE Asian type and cytosine in Indian type (Fig. 5.4.). This substitution is in a coding region but is synonymous and transitional. Since all the other haplotypes, including O. longinoda, had a cytosine at site 27, this thymine substitution of SE Asian type is parsimoniously considered to be derived, suggesting strong monophyly (Azuma et al. 2006).

Table 5.3 List of Nuclear DNA haplotypes corresponding to locality

\begin{tabular}{ll}
\hline LW $R h$ haplotypes & Locality No. \\
\hline Indian types & L08, L55, L13, L22, L05, L21, L66, L26, \\
& L33, L28, L29, L02, L34, L46, L86, L87, \\
& L82, L84, L79, L81, L85, L83, L80, L78, \\
& L76, L77, L64 \\
SE Asian types & L38, L58, L35, L54, L10, L56, L43, L49, \\
& L67, L69, L70, L71 \\
\hline
\end{tabular}




\begin{tabular}{|c|c|c|c|c|c|c|c|}
\hline $\begin{array}{c}\text { Locality } \\
\text { No. }\end{array}$ & $\begin{array}{c}\text { mtDNA } \\
\text { types }\end{array}$ & $\begin{array}{c}\text { nDNA } \\
\text { types }\end{array}$ & $\begin{array}{c}\text { Nucleotide } \\
\text { at site } 27\end{array}$ & $\begin{array}{c}\text { Locality } \\
\text { No. }\end{array}$ & $\begin{array}{c}\text { mtDNA } \\
\text { types }\end{array}$ & $\begin{array}{c}\text { nDNA } \\
\text { types }\end{array}$ & $\begin{array}{c}\text { Nucleotide } \\
\text { at site 27 }\end{array}$ \\
\hline L38 & SE Asian & SE Asian & T & L33 & Indian & Indian & C \\
\hline L35 & SE Asian & SE Asian & T & L28 & Indian & Indian & C \\
\hline L58 & SE Asian & SE Asian & T & L29 & Indian & Indian & C \\
\hline L54 & SE Asian & SE Asian & T & L02 & Indian & Indian & C \\
\hline L10 & SE Asian & SE Asian & T & L08 & Indian & Indian & C \\
\hline L56 & SE Asian & SE Asian & T & L55 & Indian & Indian & C \\
\hline L43 & SE Asian & SE Asian & T & L86 & Indian & Indian & C \\
\hline L49 & SE Asian & SE Asian & T & L87 & Indian & Indian & C \\
\hline L67 & SE Asian & SE Asian & T & L82 & Indian & Indian & C \\
\hline L69 & SE Asian & SE Asian & T & L84 & Indian & Indian & C \\
\hline L70 & SE Asian & SE Asian & T & L76 & Indian & Indian & C \\
\hline L71 & SE Asian & SE Asian & T & L77 & Indian & Indian & C \\
\hline L34 & SE Asian & Indian & C & L64 & Indian & Indian & C \\
\hline L46 & SE Asian & Indian & C & L78 & Indian & Indian & C \\
\hline L13 & Indian & Indian & C & L80 & Indian & Indian & C \\
\hline L22 & Indian & Indian & C & L83 & Indian & Indian & C \\
\hline L05 & Indian & Indian & C & L81 & Indian & Indian & C \\
\hline L21 & Indian & Indian & C & L85 & Indian & Indian & C \\
\hline L66 & Indian & Indian & C & L79 & Indian & Indian & C \\
\hline L26 & Indian & Indian & C & L26 & Indian & Indian & C \\
\hline
\end{tabular}

Site 27: Cytosine $(C)=$ Indian type; Thiamine $(T)=$ SE Asian type

Fig. 5.4 In Bangladesh, O. smaragdina types inferred from nDNA by LW Rh compared with the results of the types inferred from mtDNA. L34 and L46 showing the inconsistency in mtDNA and nDNA types. 


\section{Presence of heterozygous colony in L34 and L46}

We have identified the inconsistent mitochondrial and nuclear DNA type in the colony located in L34 and L46 (Fig. 5.5). As in the mitochondrial DNA analysis by (Rahman et al. 2017b), these two localities were identified as SE Asian type. For further confirmation, we have analyzed the nuclear DNA of additional 40 individuals from those two colonies, 24 individuals from L34 and 16 individuals from L46. Among those 24 individuals from L34, we recognized 1 individual is exactly sharing the same nucleotide sequence as Indian type and 23 individuals are true to SE Asian type. However, we have checked the 16 individuals from the colony of locality 45 and identified 05 and 11 individuals as Indian and SE Asian type, respectively. This finding indicated that in both colonies of that two localities have the mixture of both Indian and SE Asian type of Oecophylla smaragdina, which can be treated as the heterozygous colony often, used for the evidence of hybridization. 


\section{Inconsistency in mitochondrial and nuclear DNA}

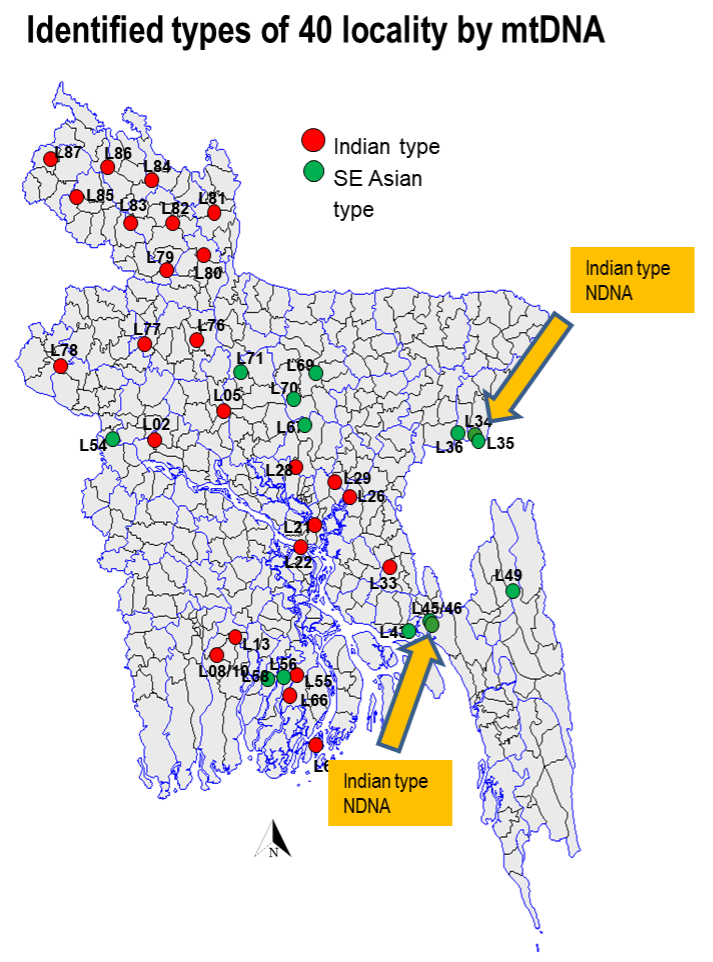

L34: 21 individuals Indian type; 1 Individual SE Asian type L46: 11 Individuals Indian type; 5 Individuals SE type

LW Rh analysis resulted

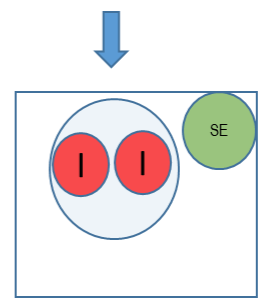

Male (India type) X Female (SE Asian type)

\section{Hybrid}

Fig. 5.5 The inconsistency of the distribution pattern of Indian and SE Asian type of $O$. smaragdina in Bangladesh inferred from mitochondrial and nuclear DNA analysis. Distribution pattern inferred by mitochondrial DNA analysis were retrieved from (Rahman et al. 2017b). The locality information is the same as mentioned in Table 3.1 


\section{Microsatellite study}

In this study, 11 microsatellite primers (MS 2.2.2, MS 2.3, MS 5.10, MS 2.14, MS 3.2, MS 6.45, MS 6.29, MS 5.2, MS 7.1, MS 8.24 and MS 6.47) (Azuma et al. 2004). However, we failed to analyze the samples using MS 5.2 microsatellite primer. For identifying the heterozygosity by the observation of number of peak by sharing the locus number were determined by electropherogrum study as mentioned in Fig. 5.6.

\section{Determining heterozygosity by electropherogrum study}

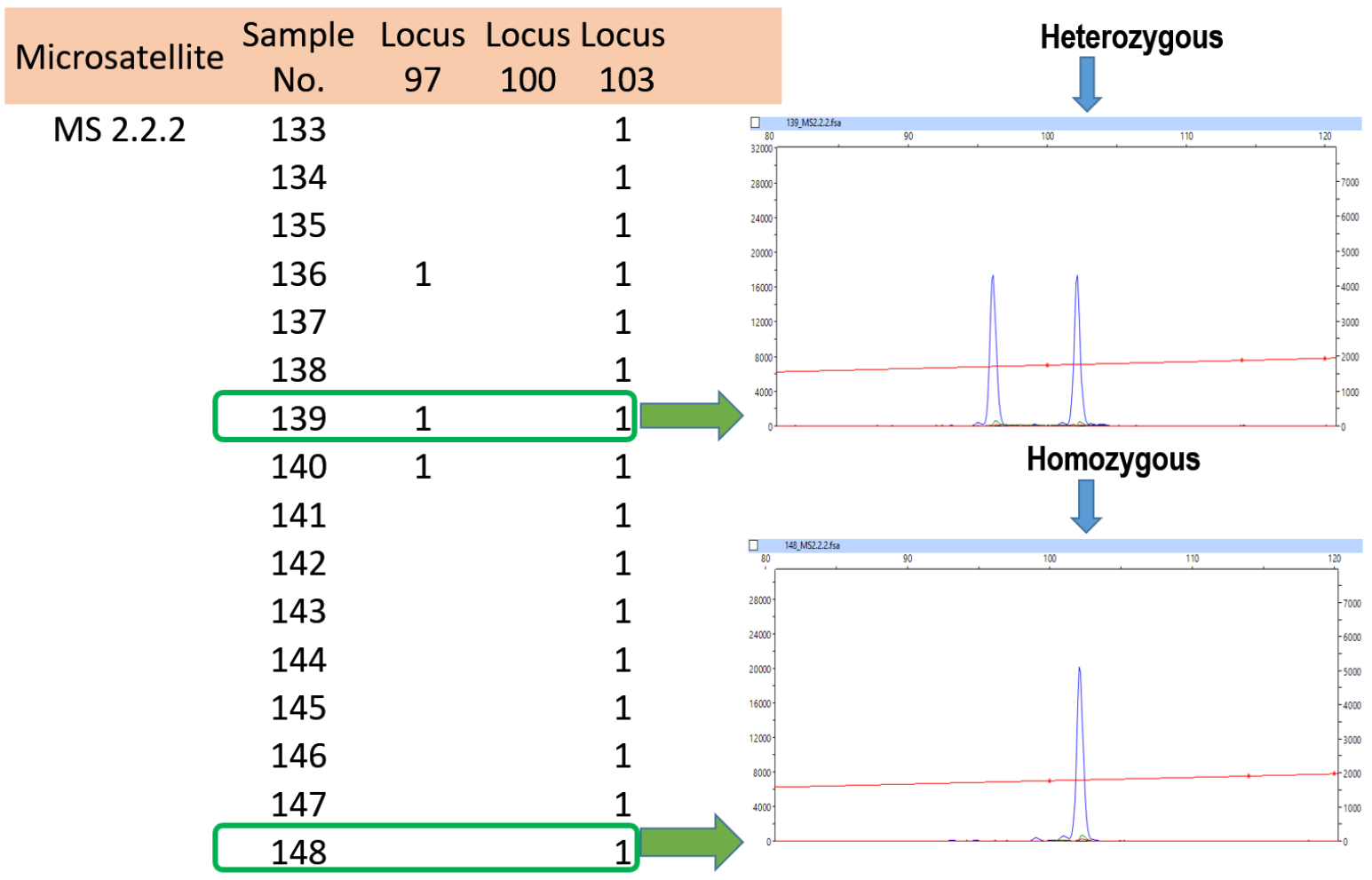

Fig. 5.6 Electropherogrum study to find out the sharing allele position of each individuals per colony. 


\subsubsection{Microsatellite markers failed to detect identical allele}

\section{Microsatellite primer MS 5.10}

With this primer, we analyzed a total of 68 samples from 7 localities. Among them, all the samples from the locality L4, L46, L27, L67 L50 and L66 were sharing both the locus 98 and locus 99 while the samples from locality 13 sharing both the locus 96 and locus 97 . L13 was identified as Indian type of Oecophylla smaragdina by both mitochondrial and nuclear DNA analysis. However, L34, L46, L67, L50 was determined as SE Asian type and L27 and L66 was characterized as Indian type. So, in this case for the primer MS 5.10 we failed to distinguish identical alleles for Indian and SE Asian type although we found heterozygosity as it showed the two peak in almost all the samples.

\section{Microsatellite primer MS 2.14}

This primer detected several allele positions for Indian and SE Asian types. The samples from L46, L27 shared the locus position 231 and 234 whereas sample from L34 shared the locus 221, in addition, 1 Sample from L50 shared the locus 262 with locus 231 and locus 234. The samples from locality L13 and L66 showing a quite different pattern of sharing allele frequencies. The samples from L13, shared the locus 245, locus 247, locus 262, locus 270 and locus 273. The samples from L66 shared the locus 238, locus 252 and locus 270 (Table 5.4). So, no distinguished locus position sharing by Indian and SE Asian types of samples were observed.

\section{Microsatellite primer MS 3.2}

For identifying the identical allele, I tested 32 samples from 4 localities. The samples from L27 and L67 shared the locus 81 while the samples from L13 shared the locus 86 . The samples from locality 50 are sharedboth locus 81 and locus 86 (Table 5.4). 


\section{Microsatellite primer MS 7.1, MS 6.29 and MS 6.47}

Eight samples from each of two localities (L67 and L13) were tested by microsatellite primer MS 7.1, MS 6.29 and MS 6.47. All 08 samples shared the locus 100, locus 128 and locus locus 172 for MS 7.1, MS 6.47 and MS 6.29, respectively (Table 5.4). So, no locus was identified that can separate Indian and SE Asian type of Oecophylla in Bangladesh.

\section{Microsatellite primer MS 2.3 and MS 2.2.2}

60 samples from 7 locaities were tested each for MS 2.3 and MS 2.2.2. All the samples from MS 2.3 shared the locus 144, while two samples from L34 and L46 shared both the loci 100 and 144. In the case of MS 2.2.2, all the samples sharing the locus 103 except the samples from L13 and L66 that were sharing the locus 97. The samples from other locality that were identified as Indian type also shared the locus position 97 along with some samples from L34 which was identified as SE Asian type. So, with these two primers the identical allele position was not possible to distinguish between Indian and SE Asian types (Table 5.4).

\subsubsection{Detection of identical allele}

The identical allele between Indian and SE Asian type of Oecophylla population in Bangladesh were possibly detected with the microsatellite primer MS 6.45 and MS 8.24. For MS 6.45, four samples from the locality L67 were analyzed and all 04 samples shared the locus 238. However, the samples from locality L13 shared the locus 244 and locus 250 . As the colony of L13 locality was identified as Indian type and L67 was SE Asian type so, these locus position was identical. Similarly, the samples with 8.24, among 08 samples, 4 samples from L67 shared the loucs 277 while the rest 4 samples from locality L13 shared the locus 262 (Table 5.4) 
Table 5.4 Allele record for 10 microsatellite loci on 7 localities. $\mathrm{n}$ indicating the number of individuals/ locality

\begin{tabular}{|c|c|c|c|c|c|c|c|c|}
\hline \multicolumn{2}{|c|}{$\begin{array}{c}\text { Microsatellite Allele } \\
\text { mt DNA type }\end{array}$} & $\begin{array}{l}\text { L34 }(n=8) \\
\text { SE Asian }\end{array}$ & $\begin{array}{l}\text { L46 }(n=8) \\
\text { SE Asian }\end{array}$ & $\begin{array}{l}\text { L27 }(n=8) \\
\text { Indian }\end{array}$ & $\begin{array}{l}\text { L67 }(n=8) \\
\text { SE Asian }\end{array}$ & $\begin{array}{l}\text { L13 }(n=8) \\
\text { Indian }\end{array}$ & $\begin{array}{l}\text { L50 }(n=8) \\
\text { SE Asian }\end{array}$ & $\begin{array}{l}\text { L66 }(n=8) \\
\text { Indian }\end{array}$ \\
\hline \multirow[t]{3}{*}{ MS 2.2.2 } & 97 & 3 & & 4 & & 8 & 1 & 8 \\
\hline & 100 & & & & & & & \\
\hline & 103 & 8 & 8 & 4 & 8 & & 8 & \\
\hline \multicolumn{2}{|c|}{ \% Heterozygosity } & 37.5 & 0 & 50 & 0 & 0 & 12.5 & 0 \\
\hline \multirow[t]{2}{*}{ MS 2.3} & 100 & 1 & 1 & & & & & \\
\hline & 144 & 8 & 8 & 8 & 8 & 8 & 8 & 8 \\
\hline \multicolumn{2}{|c|}{$\%$ Heterozygosity } & 12.5 & 12.5 & 0 & 0 & 0 & 0 & 0 \\
\hline \multirow[t]{4}{*}{ MS 5.10} & 96 & & & & & 8 & & \\
\hline & 97 & & & & & 8 & & \\
\hline & 98 & 8 & 8 & 8 & 8 & & 8 & 8 \\
\hline & 99 & 8 & 8 & 8 & 8 & & 8 & 8 \\
\hline \multicolumn{2}{|c|}{$\%$ Heterozygosity } & 100 & 100 & 100 & 100 & 100 & 100 & 100 \\
\hline \multirow[t]{11}{*}{ MS 2.14} & 221 & 4 & & & & & & \\
\hline & 231 & 3 & 6 & 8 & & & 5 & \\
\hline & 234 & 5 & 8 & 5 & 8 & & 8 & \\
\hline & 238 & & & & & & & 4 \\
\hline & 245 & & & & & 5 & & \\
\hline & 247 & & & & & 3 & & \\
\hline & 252 & & & & & & & 3 \\
\hline & 258 & & & & & 4 & 1 & \\
\hline & 262 & & & & & & & 8 \\
\hline & 270 & & & & & 1 & & \\
\hline & 273 & & & & & 3 & & \\
\hline \multicolumn{2}{|c|}{ \% Heterozygosity } & 50 & 62.5 & 62.5 & 0 & 100 & 75 & 87.5 \\
\hline \multirow[t]{2}{*}{ MS 3.2} & 81 & & & 8 & 8 & & 7 & \\
\hline & 86 & & & & & 8 & 8 & \\
\hline \multicolumn{2}{|c|}{ \% Heterozygosity } & & & 0 & 0 & 0 & 87.5 & \\
\hline \multirow[t]{3}{*}{ MS 6.45} & 238 & & & & 4 & & & \\
\hline & 244 & & & & & 4 & & \\
\hline & 250 & & & & & 2 & & \\
\hline \multicolumn{2}{|c|}{ \% Heterozygosity } & & & & 0 & 50 & & \\
\hline MS 6.29 & 172 & & & & 4 & 4 & & \\
\hline \multicolumn{2}{|c|}{$\%$ Heterozygosity } & & & & 0 & 0 & & \\
\hline MS 7.1 & 100 & & & & 4 & 4 & & \\
\hline \multicolumn{2}{|c|}{ \% Heterozygosity } & & & & 0 & 0 & & \\
\hline \multirow[t]{2}{*}{ MS 8.24} & 262 & & & & 4 & & & \\
\hline & 277 & & & & & 4 & & \\
\hline \multicolumn{2}{|c|}{ \% Heterozygosity } & & & & 0 & 0 & & \\
\hline MS 6.47 & 128 & & & & 4 & 4 & & \\
\hline \multicolumn{2}{|c|}{$\%$ Heterozygosity } & & & & 0 & 0 & & \\
\hline MS 5.2 & Failed & & & & & & & \\
\hline
\end{tabular}


There was not too many evidence of such heterozygous condition within the colony of Oecophylla in India or any other SE Asian country and this is the first report of such mixed colony in Bangladesh as well. Similarly, Roos et al. (2011) studied tracing the evolution and hybridization of colobine monkey in the Asian continent, found several hybridization patterns by testing the mitochondrial and nuclear DNA. This hybridization among ancestral lineages most likely causes for the observed phylogenetic incongruences, due to the presence of potential contact zones like today's Bangladesh, Myanmar and the northeast of India, which is suggested as hybridization area (Karanth et al., 2008). However, several big mountains and big rivers in the border region of today's Myanmar, India and China might have been a possible diversification hotspot (Chakraborty et al. 2007) which leads to develop such hybridization pattern.

Divergence time is also an important factor for many ant genera. Oecophylla is thought to be a significant factor in such distribution. Diversification within groups in this continent was recorded from the middle Pliocene to early Pleistocene (Azuma et al. 2002). After this period, the world has encountered a significant climatic change. It might also affect the distribution of Oecophylla in different parts of the world. During Last Glacial Maximum (LGM), the tropic region shifted southward and it retained northward after glaciation. This study suggested that the Indian and Southeast Asian clades of O. smaragdina expanded their distribution northward along suitable regions with high temperature and humidity, and then the two clades supposedly encountered and overlapped in central Bangladesh. Similar trends were also observed in the case of study of the origin of Asian elephants (Vidya et al. 2009). They suggested a contractionexpansion scenario during climatic oscillation leads to geographical overlaps of two mtDNA clades created the allopatric population of Asian elephants in India, Sri Lanka, and Myanmar. In the case of weaver ant in Bangladesh, as both the Indian and SE Asian types were dominated 
in Western part and Eastern part of the country, respectively, and there was not such a big border of separating those two populations (Rahman et al. 2017a). The probability of the contact of both the types was considered very usual. Pusch et al. (2006) reported that ant colony with heterozygous produce hybrid workers. This type of gene introgression may increase the genetic diversity of the hybrid relative to its parental species and can lead to hybrid vigor. In this case, the Oecophylla colony from the locality 11 and 15 in Bangladesh might have the influence of the arising of new evolutionary lineages. This hybridization therefore, can be considered as a process of the evolutionary significance of Oecophylla smaragdina in Bangladesh.

\section{Limitation of the study}

For testing the degree of mixture of Indian and SE Asian type within the colony from the locality 34 and locality 46, I needed to analyze number of individuals from that colony. However, due to a shortage of sufficient individuals from that colony, we could not perform the study a bit more details with more samples to confirm the degree of heterozygosity or introgression of gene flow. 


\section{CHAPTER 6}

\section{GENERAL DISCUSSION AND CONCLUSIONS}




\section{CHAPTER 6}

\section{General discussion and conclusions}

\subsection{General discussion}

The present study started by checking the occurrence of SE Asian type of mtDNA in Bangladesh reported in previous studies (Azuma et al. 2002, 2006). When the survey began in the western Bangladesh, all the samples collected from Rajshahi, Khulna and Dhaka Divisions showed the Indian type of mtDNA. The following survey confirms the occurrence of SE Asian type in Chittagong and Sylhet Divisions. These were answer of the first question whether all the O. smaragdina populations in Bangladesh belong to SE Asian type.

The occurrence of both types leads to the second question where the boundary of SE Asian type and Indian type is. As Bangladesh is a riverine country with three main rivers the Ganges, Jamuna, and Meghna, the river might have some influence of separating the Indian type and the SE Asian type in Bangladesh. To check the hypothesis the study covers 87 sites of 47 districts which are divided into 7 major areas separated by the Ganges, Jamuna, and Meghna Rivers. As Bangladesh is a riverine country with three main rivers the Ganges, Jamuna, and Meghna crisscrossed throughout the mostly flat territories of the country, the river might have some influence of separating the Indian clade and the Southeast Asian clade in Bangladesh. However, the recent study revealed that the western Bangladesh population of $O$. smaragdina was dominated by Indian type (Rahman et al. 2017b). With the recognition of Indian type in western part of Bangladesh, it is clear that Indian mitochondrial haplotypes occurred on both 
sides of Ganges river. Oecophylla species may disperse via nuptial flight of queens and/or rafting method which is very effective between island to island dispersal (Peng et al. 1998).

The result of distribution of mtDNA types shows that the western parts of Bangladesh is predominantly occupied by the Indian type, whereas the eastern part by the SE Asian type, and that the central parts is the mixture of both types. The study does not show the clear boundary, but suggests the central part as a transition zone. The haplotype network analysis implys the diversity within each of the types: the Indian type includes 14 haplobtypes and the SE Asian type includes 11 haplotypes.

Effects of temperature and rainfall influence the distribution of O. smaragdina as the combination of high temperature and high rainfall is necessary to continue the weaver ant growth rate and distribution, and to a limited extent, higher temperatures can compensate for lower than optimal rainfall levels, and vice versa (Lokkers, 1986). During the glaciation period the temperature had fall down nearly $10{ }^{\circ} \mathrm{C}$ in Vostok (Lowe and Walker, 1997) might have significant influence of the distribution of several species like Oecophylla, which is markedly affected by low temperature for their colony development. The haplotype network distribution pattern (in chapter 4) also showed that the bottleneck effects might be responsible for such distribution. Due to several glaciation during Pleistocene could be a key factor of such effects. Weterrer (2017) showed a comprehensive distribution pattern of O. smaragdina in the arid, tropical and subtropical climatic region that also shed lighted the effects of temperature on the distribution. 


\section{A hypothesis forming the distribution pattern}

The occurrence of two types (Indian type and SE Asian type) in Bangladesh will be made by the following dispersal scenario: The disjunction of populations would occur several times as in shown of divergent time in 7 major groups of mtDNA, and the isolated populations may develop their unique haplotypes in India, in SE Asia, or others during the history of $O$. smaragdina which was estimated to diverged from longinoda about 13 - 11 Ma (Azuma et al. 2006; Blamer et al. 2015).

Before the Last Glacial Maximum (LGM: 25,000 - 15,000 BP) the haplotypes observed in Bangladesh would be already established. During the LGM, the Bengal Delta supposed to be vacant for Oecophylla smaragdina distribution because the northern limit of the species would be located down to the south. After the LGM, the populations expanded to north, and because of the geographical shape the east and west populations met in the Bengal Delta. When the two types of population groups met again in the Bengal Delta, each of the types already contained several haplotypes of mtDNA.

This vacant-reunion hypothesis requires a temperature drop in LGM, and diversification of populations before LGM. The present distribution of Oecophylla smaragdina, in particular, the northern limit of distribution is almost agree with the isothermal line of $10^{\circ} \mathrm{C}$ in the average temperature of January. Bangladesh has a distinct monsoonal season, with an average temperature in January of $18{ }^{\circ} \mathrm{C}$ in Dhaka. Thus if the mean temperature of the coldest month (MTCO) drops $8{ }^{\circ} \mathrm{C}$ or more, O. smaragdina cannot distribute in Bengal Delta. Braconnot et al. (2012) estimated the mean temperature of the coldest month (MTCO) in Asia is around 10 ${ }^{\circ} \mathrm{C}$ below. Although northern limit of distribution of $O$. smaragdina in LGM is not clear, the 
Bengal Delta is supposed to be out of the limit. After LGM, as the climate changed to warmer, the populations would extended to northward and come to Bengal Delta simultaneously. This is based on the result from the present study which revealed that there are14 haplotypes in Indian type and 11 haplotypes in SE Asian type. It is almost certain that the Indian type from west or southwest, and SE Asian type from east or southeast met in Bengal Delta. The populations extended to Bengal Delta were not uniform, because each of mtDNA types have a history of diversification in somewhere south in India and SE Asia. The diversification time was estimated in the Pliocene to Pleistocene.

The recent phylogeographic studies on insects, plants, amphibians or fishes shown the significance of Pleistocene climate changes and biogeographic barriers like mountains, rivers, seas and desserts alter the diversification, radiation and isolation of new genetic lineages within many species (Riddle et al. 2000). This climatic oscillation played the major role of forming such distribution of species by changing the genetic structure and diversity (Avise, 1994). Regarding the regions of East Asia, the glacial influence were not so extensive due to influence of monsoons formed by the Pacific Ocean and the presence of biotic zone at higher northern latitude. However, the fossil and biogeographic evidence showed the dramatic effects of climate changes thorough Asia and its impact on the distribution of several animal species is under consideration. The case of the distribution pattern of $O$. smaragdina in Bangladesh can be correlated with the distribution pattern of Asian elephants. Vidya et al. (2009), explained that in the case of the elephant haplotypes in Myanmar, rather suggested tha these haplotypes did not arise within Myanmar, but instead resulted from a northward range expansion of beta clade haplotypes during warm period from both Sri Lanka and the Sunda region followed by subsequent admixture in this region. The geological history of Bangladesh revealed that the formation has begun 350 million years ago when the Pangean supercontinent broke apart 
(Mannan, 2002). The Bengal Basin, which is the major basin of Bengal formation, began 127 million years ago when the Indian Plate rifted away from Antartica at $18 \mathrm{~cm}$ per year for 20

million years. So, after the age of glaciation, as a new vacant area with newly growing vegetation favored by the tropical climate facilitate the chance of occurrences of both the types.

\subsection{Conclusions}

Oecophylla smaragdina has the evolutionary importance in Bangladesh. Based on previous phylogeographic study I hypothesized that the species has some barriers in the geology of Bangladesh and India that inhibiting the Indian types to enter into Bangladesh. Taking the view that Ganges river might be the barrier, we checked the Oecophylla smaragdina population from the western part of Bangladesh and identified as Indian type. This was the first report of occurring Indian type in Bangladesh. So, there was not such a barrier for separating the populations.

Using O. smaragdina samples from 5 broad areas in Bangladesh based on three main rivers, the phylogenetic study of mitochondrial COI and Cytb genes revealed the western Bangladesh population of $O$. smaragdina is dominated by Indian type, the eastern Bangladesh population are of SE Asian types and the mixture of the two types were found in the central parts of Bangladesh.

Twenty four O. smaragdina haplotypes from Bangladesh were recognized. Among them, 13 haplotypes were identical to Indian types and 11 haplotypes were similar to SE Asian types. Haplotype distribution patterns was found to be similar as the general distribution. Longest mutational steps (27) determined that many missing haplotypes may remain in the refugia. 
I analyzed the divergence time of occurring Indian and SE Asian type in Bangladesh. diversification of both the types was suspected to occurr in Pleistocene. Indian type diverged ca. 2.3 Ma and SE Asian type diverged ca. 0.20 Ma corresponding to early to late Pleistocene.

The occurrence of two different lineages have the opportunity to make a hybridized colony. The overlapping zone of Indian and SE Asian type leaded the chance of this opportunity. In the nuclear DNA analysis by LW $R h$, discordance between mitochondrial and nuclear DNA genes from two localities were identified. These phenomenon suggested the possibility of hybridization. Eleven microsatellite primers on $O$. smaragdina were implied to find out the identical allele of Indian and SE Asian types. Among them, two microsatellite loci were identified to treat it as identical allele recognition.

Based on Phylogeography study we can concluded Bangladesh is a transitional zone for evolutionary significance of $O$. smaragdina distribution.

\subsection{Limitations of the study}

In this study, I focused on the O. smaragdina population in Bangladesh by collecting the samples from different areas of Bangladesh and phylogeographic study was conducted at the Institute of Tropical Agriculture laboratory, Kyushu University, Japan. We couldn't afford to bring all samples from the designated area of Bangladesh due to certain regulations. Size of sampling in a colony resulted limited number of the analyzed individuals. We do not have sufficient data from sexual castes of females and male. Lack of information on nuptial flight and the effects of seasonal variation, mode was not observed in my experiment. Lack of paleoclimate information of LGM in Bangladesh was another major limiting factors to interpret the data to some extents. 


\section{ACKNOWLEDGEMENTS}

Firstly, I would like to express deepest sense of gratitude, sincere appreciation and indebtedness to my supervisor, Prof. Dr. Kazuo Ogata, Institute of Tropical Agriculture of Kyushu University, Fukuoka, Japan for his outstanding planning, adept guidance, constant supervision, constructive criticism, inspiration and continuous support during my research work and the preparation of this dissertation. His enthusiasm, integral view on research and his effort for providing high quality research impressed me. I am really glad to be supervised by such an intellectual personality like Prof. Kazuo Ogata in my academic background.

I would like to express my heartfelt honor and indebtedness and cordial thanks to Dr. Shingo Hosoishi, Assistant Professor, Institute of Tropical Agriculture for his unreserved help, continuous support, guidance and co-operation, valuable suggestions and motivation thorough the study period.

I wish to appreciate the honorable members of my dissertation committee, Prof. Keiji Takasu, Prof. Toshiya Hirowatari and Assoc. Prof. Satoshi Kamitani, for generously offering their time, support and guidance for review of the dissertation.

My sincere thanks also goes to Dr. Ikuo Miyajima, Dr. Masara Matsumoto, Dr. Kimihiko Hyakumura and Dr. Akinori Ozaki, who provided me an opportunity to join their team as intern, and who gave access to the laboratory and research facilities. Without their precious support, it would not be possible to conduct this research.

I thank my fellow lab mates for the stimulating discussions and encouragement, and for all the fun we have had during my study period. I am deeply indebted to the Japan Ministry of Education, Culture, Sports, Science and Technology (MEXT) authorities for awarding 
scholarship to pursue $\mathrm{PhD}$ degree. Heartiest thanks and appreciation to the authority of Bangabandhu Sheikh Mujibur Rahman Agricultural University (BSMRAU) for offering every support and allowing me for successful completion of my study in Japan.

I had tremendous help and support from my family. A special mention has to go to my parents and brother who encouraged me to carry on during the most difficult times; always finding solutions when they were needed and supporting me throughout that have been a continuous source of inspiration to complete this thesis. Finally, a special thank you has to go to my wife and my son, who has been so patience and understood all the difficulties and made huge sacrifices to make my dreams come true.

Md Mamunur Rahman

Fukuoka, Japan 


\section{REFERENCES}




\section{REFERENCES}

Aitchison, J.C., Ali, J.R., Davis, A.M., 2008. When and where did India and Asia collide? Geol. Bull. 27, 1351-1370. doi:10.1029/2006JB004706.

Ali, J., 2005. Greater India. Earth Sci. Rev. 72, 169-188. doi:10.1016/j.earscirev.2005.07.005

Archibald, S. B., Rasnitsyn, A. P., Brothers, D. J., Mathewes, R. W., 2018. Modernisation of the Hymenoptera: ants, bees, wasps, and sawflies of the early Eocene Okanagan highlands of western North America. The Canadian Entomologist. 150, 205-257.

Arnold, G., 1922. A monograph of the Formicidae of South Africa. Part V. Myrmicinae. Annals of the South African Museum 14, 579-674.

Asaka, 2010. Phylogeography of the weaver ant Oecophylla smaragdina supporting southern Indian refugia hypothesis. (Thesis). Hokkaido University, Hokkaido, Japan.

Ascher, J.S., Danforth, B.N., Ji, S., 2001. Phylogenetic utility of the major opsin in bees (Hymenoptera: Apoidea): A reassessment. Mol. Phylogenet. Evol. 19, 76-93. doi:10.1006/mpev.2001.0911

Avise, J.C., 2009. Phylogeography: Retrospect and prospect. 3, 15. doi:10.1111/j.13652699.2008.02032.x

Azuma, N., Kikuchi, T., Ogata, K., Higashi, S., 2002. Molecular phylogeny among Local populations of weaver ant Oecophylla smaragdina. Zoolog. Sci. 19, 1321-1328. doi:10.2108/zsj.19.1321 
Azuma, N., Ogata, K., Kikuchi, T., Higashi, S., 2006. Phylogeography of Asian weaver ants, Oecophylla smaragdina. Ecol. Res. 21, 126-136. doi:10.1007/s11284-0050101-6

Azuma, N., Takahashi, J., Higashi, S., Sasaki, M., 2004. Microsatellite loci for the weaver ant Oecophylla smaragdina. Mol. Ecol. Notes. 4, 608-610. doi:10.1111/j.14718286.2004.00752.x

Bar Yaacov, D., Arbel-Thau, K., Zilka, Y., Ovadia, O., Bouskila, A., Mishmar, D., 2012. Mitochondrial DNA variation, but not nuclear DNA, sharply divides morphologically identical chameleons along an ancient geographic barrier. Plos one. 7(3), e31372. doi:10.1371/journal.pone.0031372

Bingham, C.T., 1903. The fauna of British India, including Ceylon and Burma. Hymenoptera, Vol. II. Ants and Cucoo-wasps. London: Taylor and Francis. 506pp.

Blaimer, B.B., 2012. Taxonomy and species-groups of the subgenus Crematogaster (Orthocrema) in the Malagasy region (Hymenoptera, Formicidae). Zookeys 199, 23-70. doi:10.3897/zookeys.199.2631

Blaimer, B.B., Brady, S.G., Schultz, T.R., Lloyd, M.W., Fisher, B.L., Ward, P.S., 2015. Phylogenomic methods outperform traditional multi-locus approaches in resolving deep evolutionary history : a case study of formicine ants. BMC Evol. Biol. 15 (274), 1-14. doi:10.1186/s12862-015-0552-5

Bolton, B., 2018. An online catalog of the ants of the world. Available from http://antcat.org. (accessed 16 June, 2018).

Bolton, B., 1995. A new general catalogue of the ants of the world. . Harvard University Press, London. 
Bowen, G.J., 2007. Palaeoclimate: When the world turned cold. Nature. 445, 607-608. doi:10.1038/445607a.

Braconnot, P., S.P. Harrison, M. Kageyama, P.J. Bartlein, V. Masson-Delmotte, A. Abe-Ouchi, B. Otto-Bliesner and Y. Zhao. 2012. Evaluation of climate models using palaeoclimatic data. Nat Clim Change. 2, 417-424.

Brandon-jones, D., 1996. The Asian Colobinae (Mammalia: Cercopithecidae) as indicators of Quaternary climatic change. Biol. J. Linn. Soc. 59, 327-350. doi:10.1006/bij1.1996.0068

Brown, W.L., Jr., 1955. Ant taxonomy. Pp. 569-572 in: Kessel, E. W. (ed.) A century of progress in the natural sciences, 1853-1953. San Francisco: California Academy of Science, $x+807$ pp.

Brown, W.L., Jr., Carpenter, F.M., 1978. A restudy of two ants from the Sicilian amber. Psyche. 85, 417-423.

Buerki, S., Forest, F., Alvarez, N., Nylander, J.A., Arrigo, N., Sanmartín, I., 2011. An evaluation of new parsimony-based versus parametric inference methods in biogeography: A case study using the globally distributed plant family Sapindaceae. J. Biogeogr. 38, 531-550. doi:10.1111/j.1365-2699.2010.02432.x

Butler, I.A., Siletti, K., Oxley, P.R., Kronauer, D.J.C., 2014. Conserved microsatellites in ants enable population genetic and colony pedigree studies across a wide range of species. Plos One. 9(9), e107334. doi:10.1371/journal.pone.0107334

Cameron, S.A., Mardulyn, P., Brower, A., 2001. Multiple molecular data sets suggest independent origins of highly eusocial behavior in bees (Hymenoptera:Apinae). Syst. Biol. 50, 194-214. doi:10.1080/10635150120230. 
Cameron, S.A., Williams, P.H., 2003. Phylogeny of bumble bees in the new world subgenus Fervidobombus (Hymenoptera: Apidae): Congruence of molecular and morphological data. Mol. Phylogenet. Evol. 28, 552-563. doi:10.1016/S10557903(03)00056-3

Chakraborty, D., Ramakrishnan, U., Panor, J., Mishra, C., Sinha, A., 2007. Phylogenetic relationships and morphometric affinities of the Arunachal macaque Macaca munzala, a newly described primate from Arunachal Pradesh, northeastern India. Mol. Phylogenet. Evol. 44, 838-849. doi:10.1016/j.ympev.2007.04.007

Clement, M., Posada, D., Crandall, K.A., 2000. TCS: A computer program to estimate gene genealogies. Mol. Ecol. 9, 1657-1659. doi:10.1046/j.1365-294X.2000.01020.x.

Cockerell, T. D. A., 1915. British fossil insects. Proceedings of the United States National Museum. 49, 469-499.

Cockerell, T. D. A., 1920. Fossil arthropods in the British Museum. - I. Annals and Magazine of Natural History. (9)5, 273-279.

Crozier, R.H., Crozier, Y.C., 1993. The mitochondrial genome of the honeybee Apis mellifera: Complete sequence and genome organization. Genetics. 133, 97-117. doi:10.1111/j.1365-2583.1993.tb00131.x

Crozier, R.H., Dobric, N., Imai, H.T., Graur, D., Cornuet, J.M., Taylor, R.W., 1995. Mitochondrial-DNA sequence evidence on the phylogeny of Australian jackjumper Ants of the Myrmecia pilosula Complex. Mol. Phylogenet. Evol. 4, 2030. doi:10.1006/mpev.1995.1003 
Crozier, R.H., Newey, P.S., Schlüns, E.A., Robson, S.K.A., 2010. A masterpiece of evolution-Oecophylla weaver ants (Hymenoptera: Formicidae). Myrmecol. News. 13, 57-71.

Dalla Torre, K.W., 1893. Catalogus Hymenopterorum hucusque descriptorum systematicus et synonymicus. Vol. 7, Formicidae (Heterogyna). Leipzig: E. Engelmann, 289 pp.

Deichmüller, J.V., 1881. Fossile Insecten aus dem Diatomeenschiefer von Kutschlin bei Bilin, Böhmen. Nova Acta Academiae Caesareae Leopoldino-Carolinae Germanicae Naturae Curiosorum. 42, 293-330.

Dlussky, G. M., 1981. Miocene ants (Hymenoptera, Formicidae) of the USSR. [In Russian.]. Pp. 64-83 in: Vishnyakova, V. N.; Dlussky, G. M.; Pritykina, L. N. 1981. New fossil insects from the territories of the USSR. [In Russian.] Trudy Paleontologicheskogo Instituta. Akademiya Nauk SSSR. 183, 1-87.

Dlussky, G. M., Karl, H.-V., Brauckmann, C., Gröning, E., Reich, M., 2011. Two ants (Insecta: Hymenoptera: Formicidae: Formicinae) from the Late Pliocene of Willershausen, Germany, with a nomenclatural note on the genus Camponotites. Paläontologische Zeitschrift. 85, 449-455.

Dlussky, G. M., Perfilieva, K. S., 2014. Superfamily Formicoidea Latreille, 1802. 410438 in Antropov, A. V., Belokobylskij, S. A., Compton, S. G., Dlussky, G. M., Khalaim, A. I., Kolyada, V. A., Kozlov, M. A., Perfilieva, K. S., Rasnitsyn, A. P., 2014. The wasps, bees and ants (Insecta: Vespida=Hymenoptera) from the Insect Limestone (Late Eocene) of the Isle of Wight, UK. Earth and Environmental Science Transactions of the Royal Society of Edinburgh. 104(34), 335-446. 
Dlussky, G. M., Rasnitsyn, A. P., 1999. Two new species of aculeate Hymenoptera (Vespida = Hymenoptera) from the middle Eocene of the United States. Paleontol. J. 33, 546-549.

Dlussky, G.M., Wappler, T., and Wedmann, S., 2009. Fossil ants of the genus Gesomyrmex Mayr (Hymenoptera, Formicidae) from the Eocene of Europe and remarks on the evolution of arboreal ant communities. Zootaxa, 2031, 1-20.

Dlussky, G.M., Wappler, T., Wedmann, S., 2008. New middle Eocene formicid species from Germany and the evolution of weaver ants. Acta Palaeontol. Pol. 53, 615-626. doi:10.4202/app.2008.0406

Dowling, T.E., DeMaris, B.D., 1993. Evolutionary significance of introgressive hybridization in cyprinid fishes. Nature. $362,444-446$.

Dowling, T.E., Smith, G.R., Brown, W.M., 1989. Reproductive isolation and introgression between Notropis cornutus and Notropis chrysocephalus (family cyprinidae): comparison of morphology, allozymes, and mitochondrial DNA Evolution. 43 (3), 620-634.

Drummond, A.J., Ho, S.Y.W., Phillips, M.J., Rambaut, A., 2006. Relaxed phylogenetics and dating with confidence. Plos Biol. 4(5), e88.doi:10.1371/journal.pbio.004 0088

Emery, C., 1887. Catalogo delle formiche esistenti nelle collezioni del Museo Civico di Genova. Parte terza. Formiche della regione Indo-Malese e dell'Australia. [part]. Annali del Museo Civico di Storia Naturale. 24, 209-240.

Emery, C., 1925. Hymenoptera. Fam. Formicidae. Subfam. Formicinae. Genera Insectorum. $183,1-302$.

Eto, K., Matsui, M., Sugahara, T., 2013. Discordance between mitochondrial DNA genealogy and nuclear DNA genetic structure in the two morphotypes of rana tagoi tagoi 
(amphibia: anura : ranidae) in the Kinki Region, Japan while the small type remains unnamed . Zool. Sci. 558, 553-558. doi:10.2108/zsj.30.553

Fabricius, J.C., 1775. Systema entomologiae, sistens insectorum classes, ordines, genera, species adiectis synonymis, locis, descriptionibus, observationibus. Flensburgi et Lipsiae: Korte. 832 pp.

Faure, E., Casanova, J., 2006. Comparison of chaetognath mitochondrial genomes and phylogenetical implications. Mitochondrion. 6, 258-262. doi:10.1016/j.mito.2006.07.004

Faure, E., Delaye, L., Tribolo, S., Levasseur, A., Seligmann, H., Barthélémy, R., 2011. Probable presence of an ubiquitous cryptic mitochondrial gene on the antisense strand of the cytochrome oxidase I gene. Biol. Direct. 6, 56. doi:10.1186/1745$6150-6-56$

Felsenstein, J., 1981. Evolutionary trees from DNA Sequences: A maximum likelihood approach. J. Mol. Evol.17, 368-376.

Forel, A., 1915. Results of Dr. E. Mjöbergs Swedish Scientific Expeditions to Australia 191013. 2. Ameisen. Arkiv for Zoologi. 9 (16), 1-119.

Gibbons, A.D., Kiel, D.-, Bogaard, P. Van Den, Hoernle, K., Werner, R., Müller, R.D., 2012. Tectonic evolution of the West Australian margin. Geochem. Geophys. Geosyst. 13, Q05W13, 13, 1-25. doi:10.1029/2011GC003919

Goodbred, S.L., 2003. Response of the Ganges dispersal system to climate change: A sourceto-sink view since the last interstade. Sediment. Geol. 162, 83-104. doi:10.1016/S0037-0738(03)00217-3 
Goodbred, S.L., Kuehl, S.A., 2000. The significance of large sediment supply, active tectonism, and eustasy on margin sequence development: Late Quaternary stratigraphy and evolution of the Ganges-Brahmaputra delta. Sediment. Geol. 133, 227-248. doi:10.1016/S0037-0738(00)00041-5

Goodman, S.J., Barton, N.H., Swanson, G., Abernethy, K., Pemberton, J.M., 1999. Introgression Through Rare Hybridization : A Genetic Study of a Hybrid Zone Between Red and Sika Deer (Genus Cervus ) in Argyll, Scotland. Genetics. 152, $355-371$.

Guérin-Méneville, F. E., 1831. Insectes, plate 8. In: Duperrey, L. I. (ed.) 1831. 1830-1831. Voyage autour du monde, exécuté par ordre du Roi, sur la corvette de sa Majesté, La Coquille, pendant les années 1822, 1823, 1824 et 1825. Zoologie. Atlas, Insectes. Paris: H. Bertrand, pls. 1-21, 14 bis.

Guérin-Méneville, F. E., 1838. Première division. Crustacés, arachnides et insectes. In: Duperrey, L. I. (ed.) 1838. Voyage autour du monde, executé par ordre du Roi, sur la corvette de sa Majesté, La Coquille, pendant les années 1822, 1823, 1824 et 1825. Zoologie. Tome deuxième. Part 2. Paris: H. Bertrand, xii + 9-320 pp.

Hall, R., 2009. Southeast Asia's changing palaeogeography. Blumea J. Plant Taxon. Plant Geogr. 54, 148-161. doi:10.3767/000651909X475941

Heer, O., 1847. Die Insektenfauna der Tertiärgebilde von Oeningen und von Radoboj in Croatien. Erster Theil: Käfer. 1-229.

Heer, O., 1849. Die Insektenfauna der Tertiärgebilde von Oeningen und von Radoboj in Croatien. Zweiter Theil: Henschrecken, Florfliegen, Aderflügler, Schmetterlinge und Fliegen. 1-264.

Heer, O., 1865. Die Urwelt der Schweiz. 1-622. 
Hewitt, G.M., 2004. Genetic consequences of climatic oscillations in the Quaternary. Phil. Trans. R. Soc. Lond. B. 359, 183-195. doi:10.1098/rstb.2003.1388

Holl, F., 1829. Handbuch der Petrefactenkunde 2, 117-232.

Hölldobler, B.K., Wilson, E.O., 1977. Weaver Ants. Sci. Am. 237, 146-154. doi:10.1038/scientificamerican1277-146.

Hoorn, C., Wesselingh, F.P., Steege, H., Bermudez, M.A., Mora, A., Sevink, J., Sanmartín, I., Anderson, C.L., Figueiredo, J.P., Jaramillo, C., Riff, D., 2010. Amazonia through time: Andean Uplift, Climate Change, Landscape Evolution, and Biodiversity. Science. 330, 927-931.

Karanth, K.P., Singh, L., Collura, R. V., Stewart, C.B., 2008. Molecular phylogeny and biogeography of langurs and leaf monkeys of South Asia (Primates: Colobinae). Mol. Phylogenet. Evol. 46, 683-694. doi:10.1016/j.ympev.2007.11.026

Karavaiev, V., 1933 ("1932"). Ameisen aus dem Indo-Australischen Gebiet, VII. Konowia 11, 305-320.

Katz, M.E., Miller, K.G., Wright, J.D., Wade, B.S., Browning, J. V., Cramer, B.S., Rosenthal, Y., 2008. Stepwise transition from the Eocene greenhouse to the Oligocene icehouse. Nat. Geosci. 1, 329-334. doi:10.1038/ngeo179

Kirby, W., 1819 ("1818"). A description of several new species of insects collected in New Holland by Robert Brown, Esq. F.R.S. Lib. Linn. Soc. Transactions of the Linnean Society of London 12, 454-478.

Kronauer, D.J.C., Peters, M.K., Schöning, C., Boomsma, J.J., 2011. Hybridization in East African swarm-raiding army ants. Front. Zool. 8, 20. 
Kurane, S., Bhoje, P.M., Sathe, T.V., 2015. on a New Species of the Genus Oecophylla ( Hymenoptera : Formicidae ). Flora and Fauna. 21, 197-199.

Latreille, P. A., 1802. Histoire naturelle des fourmis, et recueil de mémoires et d'observations sur les abeilles, les araignées, les faucheurs, et autres insectes. Paris: Impr. Crapelet (chez T. Barrois), xvi +445 pp.

Lokkers, C., 1986. The distribution of the weaver ant, Oecophylla smaragdina (Fabricius) (Hymenoptera: Formicidae) in northern Australia. Aust. J. Zool. 34(5), 683-687. doi:10.1071/ZO9860683

Lowe, J.J. and Walker, M.J.C., 1997. Reconstructing Quaternary Environments. 2nd Edition. 1997, Harlow, England: Prentice Hall. 446.

Luciano B. Beheregaray, 2008. Twenty years of phylogeography : the state of the field and the challenges for the Southern hemisphere. Mol. Ecol. 17, 3754-3774. doi:10.1111/j.1365-294X.2008.03857.x

Lunt, D.H., Zhang, D.X., Szymura, J.M., Hewitt, G.M., 1996. The insect cytochrome oxidase I gene: evolutionary patterns and conserved primers for phylogenetic studies. Insect Mol. Biol. 5, 153-165. doi:10.1111/j.1365-2583.1996.tb00049.x

Mallet, J., 2007. Subspecies, semispecies, superspecies. In Levin, S. et al. (eds.) Encyclopedia of Biodiversity. Volume 5. Academic Press. pp. 523-526. Online update 1, pp. 1-5, Elsevier, Oxford.

Mallet, J., 2005. Hybridization as an invasion of the genome. Trends Ecol. Evol. 20(5), 229237. doi:10.1016/j.tree.2005.02.010. 
Mannan, A., 2002. Stratigraphic evolution and geochemistry of the Neogene Surma Group, Surma Basin, Sylhet, Bangladesh. Dep. Geol. University of Oulu. http://herkules.oulu.fi/issn03553191/)

Mardulyn, P., Cameron, S.A., 1999. The major opsin in bees (Insecta: Hymenoptera): A promising nuclear gene for higher level phylogenetics. Mol. Phylogenet. Evol. 12, 168-176. doi:10.1006/mpev.1998.0606

Mauro, D.S., Gower, D.J., Zardoya, R., Wilkinson, M., 2006. A hotspot of gene order rearrangement by tandem duplication and random loss in the vertebrate mitochondrial genome. Mol. Biol. Evol. 23 (1), 227-234. doi:10.1093/molbev/msj025

Mayr, E., 1942. Systematics and the origin of species. Columbia Univ. Press.

Mayr, G., 1863. Formicidarum index synonymicus. Verhandlungen der KaiserlichKöniglichen Zoologisch-Botanischen Gesellschaft in Wien. 13, 385-460.

Mayr, G., 1868. Die Ameisen des baltischen Bernsteins. Beiträge zur Naturkunde Preussens. $1,1-102$

Mayr, G., 1872. Formicidae Borneenses collectae a J. Doria et O Beccari in territorio Sarawak annis 1865-1867. Annali del Museo Civico di Stroria Naturale. 2, 133-155.

Menge, A., 1854. Footnotes and taxonomic names, in Die im Bernstein befindlichen Crustaceen, Myriapoden, Arachniden und Apteren der Vorwelt. In G. Berendt (ed.), Die in Bernstein Befindlichen Organischen Reste der Vorwelt Gesammelt in Verbindung mit Mehreren Bearbeitetet und Herausgegeben 1(2), 1-124.

Nascimento, F.F., Reis, M. Dos, Yang, Z., 2017. A biologist's guide to Bayesian phylogenetic analysis. Nat. Ecol. Evol. 1, 1446-1454. doi:10.1038/s41559-017-0280-x 
Nylander, J.A.A., 2004. MrModeltest v2. Program distributed by the author. Evol. Biol. Cent. Uppsala Univ. 2, 1-2.

Patwardhan, A., Ray, S., Roy, A., 2014. Molecular markers in phylogenetic studies - A review. J. Phylogen. Evol. Biol. 2, 131. doi:10.4172/2329-9002.1000131

Peel, M.C., Finlayson, B.L., Mcmahon, T.A., 2007. Updated world map of the K * oppenGeiger climate classification. Hydrol. Earth Syst. Sci. 11, 1633-1644.

Perfilieva, K. S., Dubovikoff, D. A., Dlussky, G. M., 2017. Miocene ants (Hymenoptera, Formicidae) from Crimea. Paleontol. J. 51, 391-401.

Pickering, J.L., Goodbred, S.L., Reitz, M.D., Hartzog, T.R., Mondal, D.R., Hossain, M.S., 2014. Late Quaternary sedimentary record and Holocene channel avulsions of the Jamuna and old Brahmaputra river valleys in the upper Bengal delta plain. Geomorphology. 227, 123-136. doi:10.1016/j.geomorph.2013.09.021

Posada, D., Crandall, K.A., 1998. MODELTEST: Testing the model of DNA substitution. Bioinformatics. 14, 817-818. doi:10.1093/bioinformatics/14.9.817

Pusch, K., Heinze, J., Foitzik, S., 2006. The influence of hybridization on colony structure in the ant species Temnothorax nylanderi and T. crassispinus. Insectes Soc. 53, 439-445. doi:10.1007/s00040-005-0891-8

Rahman, M.M., Hosoishi, S., Ogata, K., 2017a. Phylogenetic position of the western Bangladesh populations of weaver ant, Oecophylla smaragdina (Fabricius) (Hymenoptera, $\quad$ Formicidae). $\quad$ Sociobiology. $\quad 64, \quad$ doi:10.13102/sociobiology.v64i4.1153 
Rahman, M.M., Hosoishi, S., Ogata, K., 2017b. Phylogenetic analysis reveals the overlapping distribution of the Indian and southeast Asian clades of Oecophylla smaragdina (Fabricius).尹. Fac. Agr., Kyushu Univ. 62 (2), 429-434.

Randi, E., Lucchini, V., Hennache, A., Kimball, R.T., Braun, E.L., Ligon, J.D., 2001. Evolution of the mitochondrial DNA control region and cytochrome $b$ genes and the inference of phylogenetic relationships in the avian genus Lophura (Galliformes). Mol. Phylogenet. Evol. 19, 187-201. doi:10.1006/mpev.2001.0922

Rashid, B., Sultan-Ul-Islam, Islam, B., 2015. Sub-surface geology and evolution of the Barind tract, Bangladesh. Am. J. Earth Sci. 2, 22-38.

Rashid, T., Monsur, H., Suzuki, S., 2006. A review on the quaternary characteristics of Pleistocene tracts of Bangladesh. Earth Sci. Reports. 13(1), 1-13.

Rawlings, T. A, Collins, T.M., Bieler, R., 2001. A major mitochondrial gene rearrangement among closely related species. Mol. Biol. Evol. 18, 1604-1609. doi:10.1093/oxfordjournals.molbev.a003949

Riddle, B.R., Hafner, D.J., Alexander, L.F., 2000. Phylogeography and systematics of the Peromyscus eremicus species group and the historical biogeography of North American warm regional deserts. Mol. Phylogenet. Evol. 17, 145-160. doi:10.1006/mpev.2000.0841

Riou, B., 1999. Descriptions de quelques insectes fossiles du Miocène supérieur de la Montagne d'Andance (Ardèche, France). EPHE Biologie et Evolution des Insectes 11-12, 123-133. 
Roger, J., 1863. Verzeichniss der Formiciden-Gattungen und Arten. Berliner Entomologische Zeitschrift. 7 (Beilage), 1-65.

Ronquist, F., Huelsenbeck, J.P., 2003. MrBayes 3 : Bayesian phylogenetic inference under mixed models. Bioinformatics. $19 \quad$ (12), 1572-1574. doi:10.1093/bioinformatics/btg180

Roos, C., Zinner, D., Kubatko, L.S., Schwarz, C., Yang, M., Meyer, D., Nash, S.D., Xing, J., Batzer, M. a, Brameier, M., Leendertz, F.H., Ziegler, T., Perwitasari-Farajallah, D., Nadler, T., Walter, L., Osterholz, M., 2011. Nuclear versus mitochondrial DNA: evidence for hybridization in colobine monkeys. BMC Evol. Biol. 11, 77. doi:10.1186/1471-2148-11-77

Sameshima, S., Hasegawa, E., Kitade, O., Minaka, N., Matsumoto, T., 1999. Phylogenetic comparison of endosymbionts with their host ants based on molecular evidence. Zool. Sci 16, 993-1000. doi:Doi 10.2108/Zsj.16.993

Santschi, F., 1928. Descriptions de nouvelles fourmis éthiopiennes (suite). Revue de Zoologie et de Botanique Africaines 16, 191-213.

Schlüns, E.A., Wegener, B.J., Robson, S.K.A., 2011. Genetic polyethism and nest building in the weaver ant Oecophylla smaragdina (FABRICIUS, 1775) (Hymenoptera: Formicidae). Myrmecol. News. 15, 7-11. doi:10.1111/j.1365294x.2008.04020.x

Seal, J.N., Brown, L., Ontiveros, C., Thiebaud, J., Mueller, U.G., 2015. Gone to Texas: Phylogeography of two Trachymyrmex (Hymenoptera: Formicidae) species along the southeastern coastal plain of North America. Biol. J. Linn. Soc. 114, 689-698. doi:10.1111/bij.12426 
Smith, F., 1857. Catalogue of hymenopterous insects collected at Sarawak, Borneo, Mount Ophir, Malacca, and at Singapore, by A. R. Wallace. [part]. Journal and Proceedings of the Linnean Society of London Zoology. 2, 42-88.

Smith, F., 1860. Catalogue of hymenopterous insects collected by Mr. A. R. Wallace in the islands of Bachian, Kaisaa, Amboyna, Gilolo, and at Dory in New Guinea. Journal and Proceedings of the Linnean Society of London. Zoology. 5 (17b) (suppl. to vol. 4), 93-143.

Steiner, F.M., Seifert, B., Grasso, D.A., Le Moli, F., Arthofer, W., Stauffer, C., Crozier, R.H., Schlick-Steiner, B.C., 2011. Mixed colonies and hybridisation of Messor harvester ant species (Hymenoptera: Formicidae). Org. Divers. Evol. 11, 107134. doi:10.1007/s13127-011-0045-3

Tamura, K., Stecher, G., Peterson, D., Filipski, A., Kumar, S., 2013. MEGA6: Molecular evolutionary genetics analysis version 6.0. Mol. Biol. Evol. 30, 2725-2729. doi:10.1093/molbev/mst197.

Taylor, R.W., and Brown, D.R., 1985. Formicoidea. Zoological Catalogue of Australia. 2, 1$149,306-348$.

Theobald, N., 1937. Les insectes fossiles des terrains oligocènes de France. Bulletin Mensuel (Mémoires) de la Société des Sciences de Nancy. 1, 1-473.

Thornton, I., 1996. Krakatau: The destruction and reassembly of an island ecosystem, in: Tropical Ecology. pp. 147-148.

Uddin, A., Lundberg, N., 1999. A paleo-Brahmaputra? Subsurface lithofacies analysis of Miocene deltaic sediments in the Himalayan - Bengal system, Bangladesh. Sediment. Geol. 123, 239-254. 
Unger, F., 1841. Fossile Insecten. Nova Acta Physico-Medica Academiae Caesareae Leopoldino-Carolinae Naturae Curiosorum. 19(2), 415-428.

Vidya, T.N., Sukumar, R., Melnick, D.J., 2009. Range-wide mtDNA phylogeography yields insights into the origins of Asian elephants. Proc. R. Soc. B. 276, 893-902276, 893-902. doi:10.1098/rspb.2008.1494

Viehmeyer, H., 1913. Ameisen aus dem Kopal von. Celebes. Sttett. Ent. Zeitung. 74, 141-155. Weidner, H., and Riou, B., 1986. Termiten (Isoptera) aus dem Obermiozän von St-Bauzile (Ardèche, Frankreich). Mitteilungen aus dem Geologisch-Paläontologischen Institut der Universität Hamburg. 61, 343-365.

Wetterer, J.K., 2017. Geographic distribution of the weaver ant Oecophylla smaragdina. Asian Myrmecol. 9, 1-12. doi:10.20362/am.009004

Wheeler, W. M., 1915 ("1914"). The ants of the Baltic Amber. Schriften der PhysikalischÖkonomischen Gesellschaft zu Königsberg. 55, 1-142.

Wheeler, W.M., 1922. Ants of the American museum Congo expedition. A contribution to the myrmecology of Africa. Bull. Am. Mus. Nat. Hist. 45, 224-236.

Wilfert, L., Long, G., Leggett, H.C., Schmid-Hempel, P., Butlin, R., Martin, S.J.M., Boots, M., 2016. Honeybee disease: Deformed wing virus is a recent global epidemic in honeybees driven by Varroa mites. Science. 351 (6273), 594-597. doi:10.1126/science.aac9976

Wilson, E.O., and Taylor, R.W., 1964. A fossil ant colony: new evidence of social antiquity. Psyche. 71, 93-103.

Yasmin, R., Shahid, S., Keramat, M., 2013. Evaluation of subsurface geologic formation in the Barind tract. Geotechnical and Geological Engineering. 34 (5), p1395. 


\section{APPENDIX}

Appendix 1. Detailed locality information with GenBank accession number of sequencing data

\begin{tabular}{|c|c|c|c|c|c|c|c|c|c|c|c|c|}
\hline \multirow{2}{*}{$\begin{array}{l}\text { Locali } \\
\text {-ty } \\
\text { No. }\end{array}$} & \multirow[t]{2}{*}{ Locality Name } & \multirow{2}{*}{$\begin{array}{l}\# \text { of } \\
\text { colo } \\
\text { nies }\end{array}$} & \multirow[t]{2}{*}{ Upazila } & \multirow[t]{2}{*}{ District } & \multirow[t]{2}{*}{ Division } & \multirow{2}{*}{$\begin{array}{l}\text { Collection } \\
\text { Date }\end{array}$} & \multirow{2}{*}{$\begin{array}{l}\text { Area } \\
\text { Code }\end{array}$} & \multicolumn{3}{|c|}{ Accession number } & \multicolumn{2}{|c|}{ GPS Coordination } \\
\hline & & & & & & & & COI & Cytb & Nuclear DNA & N Latitude & E Longitude \\
\hline L01 & Ishwardi & {$[1]$} & Ishwardi & Pabna & Rajshahi & 18 Mar. 2014 & $\mathrm{~A} 01$ & KX385842 & KX430217 & & $24^{\circ} 06^{\prime} 52^{\prime \prime}$ & $89^{\circ} 04^{\prime} 52^{\prime \prime}$ \\
\hline L02 & Bonpara & {$[1]$} & Baraigram & Natore & Rajshahi & 19 Mar. 2014 & $\mathrm{~A} 01$ & KX385843 & KX430218 & KY934248 & $24^{\circ} 16^{\prime} 29^{\prime \prime}$ & $89^{\circ} 05^{\prime} 19^{\prime \prime}$ \\
\hline L03 & Tarash & {$[1]$} & Tarash & Sirajganj & Rajshahi & 18 Mar. 2014 & $\mathrm{~A} 01$ & KX385841 & KX430216 & & $24^{\circ} 21^{\prime} 59^{\prime \prime}$ & $89^{\circ} 21^{\prime} 40^{\prime \prime}$ \\
\hline L04 & Chauhali & {$[1]$} & Belkuchi & Sirajganj & Rajshahi & 19 Mar. 2014 & $\mathrm{~A} 01$ & KX389168 & KX398946 & & $24^{\circ} 30^{\prime} 61^{\prime \prime}$ & $89^{\circ} 72^{\prime} 73^{\prime \prime}$ \\
\hline L05 & $\begin{array}{l}\text { w side of Jamuna } \\
\text { Bridge }\end{array}$ & {$[1]$} & $\begin{array}{l}\text { Sirajganj } \\
\text { sadar }\end{array}$ & Sirajganj & Rajshahi & 18 Mar. 2014 & $\mathrm{~A} 01$ & KX385840 & KX430215 & KY906977 & $24^{\circ} 23^{\prime} 43^{\prime \prime}$ & $89^{\circ} 44^{\prime} 44^{\prime \prime}$ \\
\hline L06 & Panjia & {$[1]$} & Keshabpur & Jessore & Khulna & 04 Mar. 2014 & $\mathrm{~A} 02$ & KX371575 & KX398943 & & $24^{\circ} 15^{\prime}$ & $89^{\circ} 30^{\prime}$ \\
\hline L07 & Monirampur & {$[1]$} & Monirampur & Jessore & Khulna & 14 Sep. 2013 & $\mathrm{~A} 02$ & KX355139 & KX430212 & & $24^{\circ} 15^{\prime}$ & $89^{\circ} 30^{\prime}$ \\
\hline L08 & $\begin{array}{l}\text { Khulna Univ. } \\
\text { Campus }\end{array}$ & {$[2]$} & Batiaghata & Khulna & Khulna & 03 Mar. 2014 & $\mathrm{~A} 02$ & $\begin{array}{l}\text { KX379493/ } \\
\text { KX379494 }\end{array}$ & KX398942/ & KY906981 & $24^{\circ} 46^{\prime}$ & $89^{\circ} 31^{\prime}$ \\
\hline L09 & Chuknagar & {$[1]$} & Dumuria & Khulna & Khulna & 04 Mar. 2014 & $\mathrm{~A} 02$ & KX385837 & KX398944 & & $22^{\circ} 49^{\prime}$ & $89^{\circ} 18^{\prime}$ \\
\hline L10 & Batiaghata & {$[1]$} & Batiaghata & Khulna & Khulna & 15 Sep. 2013 & $\mathrm{~A} 02$ & KX389167 & & KY906986 & $24^{\circ} 45^{\prime}$ & $89^{\circ} 31^{\prime}$ \\
\hline L11 & Atulia & {$[1]$} & Shyamnagar & Satkhira & Khulna & 24 Mar. 2014 & $\mathrm{~A} 02$ & KX385844 & KX398947 & & $24^{\circ} 16^{\prime}$ & $89^{\circ} 03^{\prime}$ \\
\hline L12 & Modonpur & {$[1]$} & Tala & Satkhira & Khulna & 25 Mar. 2014 & $\mathrm{~A} 02$ & KX385845 & KX430219 & & $24^{\circ} 46^{\prime}$ & $89^{\circ} 03^{\prime}$ \\
\hline L13 & Mollahat Bazar & {$[1]$} & Mollahat & Bagerhat & Khulna & 29 Oct. 2014 & $\mathrm{~A} 02$ & & KX430220 & KY906980 & $24^{\circ} 01^{\prime} 16.6^{\prime \prime}$ & $90^{\circ} 17^{\prime} 53.7^{\prime \prime}$ \\
\hline L14 & Pachuria & [1] & $\begin{array}{l}\text { Gopalganj } \\
\text { Sadar }\end{array}$ & Gapalgonj & Dhaka & 29 Oct. 2014 & $\mathrm{~A} 02$ & KY618816 & & & $23^{\circ} 00^{\prime} 3.6^{\prime \prime}$ & $89^{\circ} 49^{\prime} 13.8^{\prime \prime}$ \\
\hline L15 & Bhanga & {$[1]$} & Bhanga & Faridpur & Dhaka & 09 Nov. 2014 & $\mathrm{~A} 02$ & KX389172 & & & $23^{\circ} 23^{\prime} 0^{\prime \prime}$ & $89^{\circ} 59^{\prime} 0^{\prime \prime}$ \\
\hline L16 & Elenga & {$[1]$} & Kalihati & Tangail & Dhaka & 18 Mar. 2014 & $\mathrm{~A} 03$ & KX385839 & KX398945 & & $24^{\circ} 23^{\prime} 01^{\prime \prime}$ & $89^{\circ} 50^{\prime} 05^{\prime \prime}$ \\
\hline L17 & Kumrail & {$[1]$} & Dharmrai & Dhaka & Dhaka & 19 Oct. 2014 & $\mathrm{~A} 03$ & KX389169 & & & $23^{\circ} 13^{\prime} 26.1^{\prime \prime}$ & $90^{\circ} 13^{\prime} 26.1^{\prime \prime}$ \\
\hline L18 & Thanamore & {$[1]$} & Dohar & Dhaka & Dhaka & 21 Oct. 2014 & $\mathrm{~A} 03$ & KX389170 & & & $23^{\circ} 36^{\prime} 49.4^{\prime \prime}$ & $90^{\circ} 07^{\prime} 13.3^{\prime \prime}$ \\
\hline L19 & Ruhitpur & {$[1]$} & Keraniganj & Dhaka & Dhaka & 21 Oct. 2014 & $\mathrm{~A} 03$ & & KY562567 & & $23^{\circ} 40^{\prime} 07^{\prime \prime}$ & $90^{\circ} 17^{\prime} 54^{\prime \prime}$ \\
\hline
\end{tabular}




\begin{tabular}{|c|c|c|c|c|c|c|c|c|c|c|c|c|}
\hline L20 & Baluakandi & {$[1]$} & Gazaria & Munshiganj & Dhaka & 21 Oct. 2014 & $\mathrm{~A} 03$ & MG967475 & & & $23^{\circ} 38^{\prime} 57.2^{\prime \prime}$ & $90^{\circ} 35^{\prime} 8.2^{\prime \prime}$ \\
\hline $\mathrm{L} 21$ & Nimtali & {$[1]$} & $\begin{array}{l}\text { Sherajdikha } \\
\mathrm{n}\end{array}$ & Munshiganj & Dhaka & 21 Oct. 2014 & $\mathrm{~A} 03$ & KY628426 & & KY906976 & $23^{\circ} 36^{\prime} 55.3^{\prime \prime}$ & $90^{\circ} 19^{\prime} 55.6^{\prime \prime}$ \\
\hline L22 & Bejgaon & {$[1]$} & Sreenagar & Munshiganj & Dhaka & 21 Oct. 2014 & A03 & & KY583087 & KY906978 & $23^{\circ} 32^{\prime} 21.3^{\prime \prime}$ & $90^{\circ} 17^{\prime} 48.2^{\prime \prime}$ \\
\hline $\mathrm{L} 23$ & Nababganj Bazar & {$[1]$} & $\begin{array}{l}\text { Narayangan } \\
\mathrm{j}\end{array}$ & Narayanganj & Dhaka & 21 Oct. 2014 & $\mathrm{~A} 03$ & & MG967471 & & $23^{\circ} 39^{\prime} 39.2^{\prime \prime}$ & $90^{\circ} 09^{\prime} 41.9^{\prime \prime}$ \\
\hline L24 & Shiddirganj & {$[1]$} & Siddhirganj & Narayanganj & Dhaka & 21 Oct. 2014 & $\mathrm{~A} 03$ & & KY562571 & & $23^{\circ} 41^{\prime} 41.8^{\prime \prime}$ & $90^{\circ} 29^{\prime} 26.5^{\prime \prime}$ \\
\hline $\mathrm{L} 25$ & Vulta & {$[1]$} & Rupganj & Narayanganji & Dhaka & 20 Oct. 2014 & $\mathrm{~A} 03$ & & KY562573 & & $23^{\circ} 46^{\prime} 50^{\prime \prime}$ & $90^{\circ} 34^{\prime} 16.5^{\prime \prime}$ \\
\hline L26 & Panchdona & {$[1]$} & Norsingdi & Norsingdi & Dhaka & 20 Oct. 2014 & A03 & KY657490 & KY562569 & KY906973 & $23^{\circ} 53^{\prime} 36.2^{\prime \prime}$ & $90^{\circ} 34^{\prime} 16.5^{\prime \prime}$ \\
\hline L27 & $\begin{array}{l}\text { Bhawal National } \\
\text { Park }\end{array}$ & {$[2]$} & Joydebpur & Gazipur & Dhaka & 17 Mar. 2014 & A03 & KX385838 & KX430214 & & $24^{\circ} 04^{\prime} 43^{\prime \prime}$ & $90^{\circ} 24^{\prime} 06^{\prime \prime}$ \\
\hline L28 & Nurbag & {$[1]$} & Kaliakoir & Gazipur & Dhaka & 22 Oct. 2014 & A03 & KX389171 & KX430221 & KY906971 & $24^{\circ} 01^{\prime} 16.6^{\prime \prime}$ & $90^{\circ} 17^{\prime} 53.7^{\prime \prime}$ \\
\hline L29 & Charpara & {$[1]$} & Kaliganj & Gazipur & Dhaka & 20 Oct. 2014 & $\mathrm{~A} 03$ & KY628425 & & KY906970 & $23^{\circ} 55^{\prime} 31.9^{\prime \prime}$ & $90^{\circ} 36^{\prime} 0.8^{\prime \prime}$ \\
\hline L30 & Zamirarchala & {$[1]$} & Kapasia & Gazipur & Dhaka & 20 Oct. 2014 & A03 & & & & $24^{\circ} 06^{\prime} 6.2^{\prime \prime}$ & $90^{\circ} 28^{\prime} 25.8^{\prime \prime}$ \\
\hline L31 & Rajbari & {$[1]$} & Sreepur & Gazipur & Dhaka & 20 Oct. 2014 & A03 & & KY562568 & & $24^{\circ} 03^{\prime} 5.7^{\prime \prime}$ & $90^{\circ} 23^{\prime} 17.8^{\prime \prime}$ \\
\hline L32 & Nimshar & {$[1]$} & Burichang & Comilla & Chittagong & 21 Oct. 2014 & A05 & MG967473 & MG967472 & & $23^{\circ} 06^{\prime} 6.2^{\prime \prime}$ & $90^{\circ} 28^{\prime} 25.8^{\prime \prime}$ \\
\hline L33 & Madhoyia & {$[1]$} & Chandina & Comilla & Chittagong & 21 Oct. 2014 & A05 & & & KY906972 & $23^{\circ} 30^{\prime} 08.5^{\prime \prime}$ & $91^{\circ} 0^{\prime} 30^{\prime \prime}$ \\
\hline L34 & Tea Resort Center & {$[3]$} & Sreemangal & Moulovibazar & Sylhet & 14 Nov. 2014 & A04 & KY618809 & KY583084 & $\begin{array}{l}\text { MF345826, } \\
\text { KY } 906974, \\
\text { KY906969 }\end{array}$ & $24^{\circ} 18^{\prime} 7.2^{\prime \prime}$ & $91^{\circ} 45^{\prime} 34.92$ \\
\hline L35 & $\begin{array}{l}\text { Lauachra National } \\
\text { Park }\end{array}$ & {$[1]$} & Sreemangal & Moulovibazar & Sylhet & 15 Nov. 2014 & A04 & KY618815 & KY583085 & & $24^{\circ} 18^{\prime} 05.7^{\prime \prime}$ & $91^{\circ} 45^{\prime} 41.0^{\prime \prime}$ \\
\hline L36 & Bahubal & {$[1]$} & Bahubal & Habiganj & Sylhet & 14 Nov. 2014 & A04 & KY618818 & KY583083 & $\begin{array}{l}\text { KY906983, } \\
\text { KY906979 }\end{array}$ & $24^{\circ} 22^{\prime} 49^{\prime \prime}$ & $91^{\circ} 24^{\prime} 46.0^{\prime \prime}$ \\
\hline L37 & Tarau & {$[1]$} & Balaganj & Sylhet & Sylhet & 15 Nov. 2014 & A04 & KY618817 & & KY906984 & $24^{\circ} 19^{\prime} 42.6^{\prime \prime}$ & $91^{\circ} 47^{\prime} 05.2^{\prime \prime}$ \\
\hline L38 & Doradarpur & {$[1]$} & $\begin{array}{l}\text { Dokshin } \\
\text { Surma }\end{array}$ & Sylhet & Sylhet & 15 Nov. 2014 & A04 & KY618810 & KY657484 & KY906988 & $24^{\circ} 46^{\prime} 40.0^{\prime \prime}$ & $91^{\circ} 47^{\prime} 01.8^{\prime \prime}$ \\
\hline L39 & Marishbunia & {$[1]$} & Teknaf & Cox's Bazar & Chittagong & 8 Sep. 2014 & A05 & MG967474 & & & $21^{\circ} 05^{\prime} 25^{\prime \prime}$ & $92^{\circ} 20^{\prime}$ \\
\hline L40 & Noakhali para & {$[1]$} & Teknaf & Cox's Bazar & Chittagong & 9 Sep. 2014 & A05 & & & & $24^{\circ} 46^{\prime} 40.0^{\prime \prime}$ & $91^{\circ} 47^{\prime} 01.8^{\prime \prime}$ \\
\hline L41 & Mondabag & {$[1]$} & Kasba & Bramhanbaria & Chittagong & 10 Aug. 2015 & A04 & KY608802 & KY657492 & & $23^{\circ} 44^{\prime} 0^{\prime \prime}$ & $91^{\circ} 10^{\prime} 0^{\prime \prime}$ \\
\hline L42 & Jogotpur & {$[1]$} & Burichang & Comilla & Chittagong & 12 Aug. 2015 & A04 & & & & $23^{\circ} 33^{\prime} 0^{\prime \prime}$ & $91^{\circ} 7^{\prime} 36^{\prime \prime}$ \\
\hline L43 & Sebarhat & {$[1]$} & Senbag & Noakhali & Chittagong & 13 Aug. 2015 & A04 & KY608803 & KY550396 & & $22^{\circ} 58^{\prime} 59.88^{\prime \prime}$ & $91^{\circ} 13^{\prime} 59.88^{\prime \prime}$ \\
\hline L44 & $\begin{array}{l}\text { Senbag Upozilla } \\
\text { Hospital }\end{array}$ & {$[1]$} & Senbag & Noakhali & Chittagong & 13 Aug. 2015 & A04 & & KY657493 & & $22^{\circ} 58^{\prime} 59.18^{\prime \prime}$ & $91^{\circ} 13^{\prime} 59.08^{\prime \prime}$ \\
\hline L45 & Mohipal & {$[1]$} & Feni sadar & Feni & Chittagong & 14 Aug. 2015 & A04 & KY618811 & KY550397 & $\begin{array}{l}\text { MF345827 } \\
\text { (S65) }\end{array}$ & $23^{\circ} 1^{\prime} 0.89^{\prime \prime}$ & $91^{\circ} 23^{\prime} 30^{\prime \prime}$ \\
\hline
\end{tabular}




\begin{tabular}{|c|c|c|c|c|c|c|c|c|c|c|c|c|}
\hline L46 & $\begin{array}{l}\text { Mohipal Primary } \\
\text { School }\end{array}$ & {$[1]$} & Feni sadar & Feni & Chittagong & 14 Aug. 2015 & $\mathrm{~A} 04$ & KY628427 & KY550398 & & $23^{\circ} 1^{\prime} 1.10^{\prime \prime}$ & $91^{\circ} 23^{\prime} 50^{\prime \prime}$ \\
\hline L47 & Raujan Bazar & {$[1]$} & Raujan & Chittagong & Chittagong & 16 Aug. 2015 & $\mathrm{~A} 05$ & & KY550399 & & $22^{\circ} 32^{\prime} 0^{\prime \prime}$ & $91^{\circ} 56^{\prime} 0^{\prime \prime}$ \\
\hline L48 & Satkania & {$[1]$} & Satkania & Chittagong & Chittagong & 16 Aug. 2015 & A05 & KY657489 & KY550400 & MF345830 & $22^{\circ} 6^{\prime} 12^{\prime \prime}$ & $92^{\circ} 4^{\prime} 50^{\prime \prime}$ \\
\hline L49 & Dighinala HRC & {$[1]$} & Dighinala & Khagrachari & Chittagong & 12 Aug. 2015 & A05 & KY608804 & KY550401 & KY934247 & $23^{\circ} 15^{\prime} 30^{\prime \prime}$ & $92^{\circ} 3^{\prime} 30^{\prime \prime}$ \\
\hline L50 & Matiranga Dhibi & {$[1]$} & Matiranga & Khagrachari & Chittagong & 18 Aug. 2015 & A05 & KY608805 & KY550402 & & $23^{\circ} 2^{\prime} 30.12^{\prime \prime}$ & $91^{\circ} 52^{\prime} 30^{\prime \prime}$ \\
\hline L51 & Ruma Karai & {$[1]$} & Ruma & Bandarban & Chittagong & 20 Aug. 2015 & $\mathrm{~A} 05$ & KY657488 & KY550403 & & $22^{\circ} 3^{\prime} 0^{\prime \prime}$ & $92^{\circ} 25^{\prime} 0.12^{\prime \prime}$ \\
\hline L52 & Kawkhali Bazar & {$[1]$} & Kawkhali & Rangamati & Chittagong & 21 Aug. 2015 & $\mathrm{~A} 05$ & KY583089 & & MF345828 & $22^{\circ} 32^{\prime} 0^{\prime \prime}$ & $92^{\circ} 1^{\prime} 0^{\prime \prime}$ \\
\hline L53 & Patia & {$[1]$} & Patia & Chittagong & Chittagong & 02 Sep. 2015 & $\mathrm{~A} 05$ & & KY562572 & & $22^{\circ} 18^{\prime} 0^{\prime \prime}$ & $91^{\circ} 59^{\prime} 0^{\prime \prime}$ \\
\hline L54 & Thanapara Sadah & {$[1]$} & Charghat & Rajshahi & Rajshahi & 23 Nov. 2015 & $\mathrm{~A} 01$ & KY628429 & & & $24^{\circ} 17^{\prime} 0^{\prime \prime}$ & $88^{\circ} 46^{\prime} 30^{\prime \prime}$ \\
\hline L55 & $\begin{array}{l}\text { Nalchiti prim. sch. } \\
\text { field }\end{array}$ & {$[1]$} & Nalchiti & Jhalokati & Barisal & 15 Feb. 2016 & $\mathrm{~A} 02$ & KY618814 & KY657585 & & $22^{\circ} 37^{\prime} 19.92^{\prime \prime}$ & $90^{\circ} 16^{\prime} 14.88^{\prime \prime}$ \\
\hline L56 & BRAC more & {$[1]$} & $\begin{array}{l}\text { Jhalokati } \\
\text { Sadar }\end{array}$ & Jhalokati & Barisal & 15 Feb. 2016 & $\mathrm{~A} 02$ & KY657491 & KY550389 & & $22^{\circ} 38^{\prime} 36^{\prime \prime}$ & $90^{\circ} 12^{\prime} 0^{\prime \prime}$ \\
\hline L57 & Baghribazar & {$[1]$} & Rajapur & Jhalokati & Barisal & 16 Feb. 2016 & $\mathrm{~A} 02$ & KY618813 & KY550388 & KY906985 & $22^{\circ} 40^{\prime} 0.12^{\prime \prime}$ & $90^{\circ} 8^{\prime} 30.12^{\prime \prime}$ \\
\hline L58 & $\begin{array}{l}\text { Kawkhali Upz P } \\
\text { Chottor }\end{array}$ & {$[1]$} & Kawkhali & Pirojpur & Barisal & 16 Feb. 2016 & $\mathrm{~A} 02$ & KY583090 & KY550390 & KY906988 & $22^{\circ} 37^{\prime} 13.08^{\prime \prime}$ & $90^{\circ} 4^{\prime} 9.84^{\prime \prime}$ \\
\hline L59 & Shakharikathi & {$[1]$} & Mathbaria & Pirojpur & Barisal & 16 Feb. 2016 & $\mathrm{~A} 02$ & KY583091 & KY550391 & KY906987 & $22^{\circ} 17^{\prime} 12.84^{\prime \prime}$ & $89^{\circ} 58^{\prime} 0.12^{\prime \prime}$ \\
\hline L60 & Rupatoli & [1] & $\begin{array}{l}\text { Barisal } \\
\text { sadar }\end{array}$ & Barisal & Barisal & 17 Feb. 2016 & $\mathrm{~A} 02$ & & KY550395 & & $22^{\circ} 48^{\prime} 0^{\prime \prime}$ & $90^{\circ} 30^{\prime} 0^{\prime \prime}$ \\
\hline L61 & Patarhat & {$[1]$} & $\begin{array}{l}\text { Mehendigan } \\
\mathrm{j}\end{array}$ & Barisal & Barisal & 18 Feb. 2016 & $\mathrm{~A} 02$ & KY583092 & KY550392 & KY906982 & $22^{\circ} 49^{\prime} 54.84^{\prime \prime}$ & $90^{\circ} 31^{\prime} 59.88^{\prime \prime}$ \\
\hline L62 & $\begin{array}{l}\text { Barguna Sadar } \\
\text { bus stand }\end{array}$ & {$[1]$} & $\begin{array}{l}\text { Barguna } \\
\text { sadar }\end{array}$ & Barguna & Barisal & 08 Feb. 2016 & $\mathrm{~A} 02$ & & KY550393 & & $22^{\circ} 9^{\prime} 2.88^{\prime \prime}$ & $90^{\circ} 7^{\prime} 35.04^{\prime \prime}$ \\
\hline L63 & PSTU & {$[1]$} & Dumki & Patuakhali & Barisal & 11 Feb. 2016 & $\mathrm{~A} 02$ & & KY550394 & & $22^{\circ} 26^{\prime} 0^{\prime \prime}$ & $90^{\circ} 22^{\prime} 0^{\prime \prime}$ \\
\hline L64 & Panpatti & {$[1]$} & Golachipa & Patuakhali & Barisal & 10 Feb. 2016 & $\mathrm{~A} 02$ & KY583093 & KY583088 & & $22^{\circ} 9^{\prime} 48^{\prime \prime}$ & $90^{\circ} 25^{\prime} 48^{\prime \prime}$ \\
\hline L65 & $\begin{array}{l}\text { Agailjhara Uni P } \\
\text { office }\end{array}$ & {$[1]$} & Agailjhara & Barisal & Barisal & 10 Feb. 2016 & A02 & KY628430 & & & $22^{\circ} 58^{\prime} 0^{\prime \prime}$ & $90^{\circ} 9^{\prime} 0^{\prime \prime}$ \\
\hline L66 & Mohespur & {$[1]$} & Bakerganj & Barisal & Barisal & 10 Feb. 2016 & $\mathrm{~A} 02$ & KY618812 & KY657486 & & $22^{\circ} 33^{\prime} 0^{\prime \prime}$ & $90^{\circ} 20^{\prime} 18^{\prime \prime}$ \\
\hline L67 & Bhaluka Bazar & {$[1]$} & Bhaluka & Mymensingh & Mymensingh & 12 Nov. 2016 & $\mathrm{~A} 03$ & KY657499 & & MF345829 & $24^{\circ} 22^{\prime} 30^{\prime \prime}$ & $90^{\circ} 22^{\prime} 42^{\prime \prime}$ \\
\hline L68 & $\begin{array}{l}\text { Trishal Primary } \\
\text { School }\end{array}$ & {$[1]$} & Trishal & Mymensingh & Mymensingh & 12 Nov. 2016 & A03 & KY657500 & & & $24^{\circ} 34^{\prime} 30^{\prime \prime}$ & $90^{\circ} 23^{\prime} 30^{\prime \prime}$ \\
\hline L69 & BAU Campus & {$[1]$} & BAU Sadar & Mymensingh & Mymensingh & 13 Nov. 2016 & $\mathrm{~A} 03$ & KY657501 & & KY906975 & $24^{\circ} 45^{\prime} 8.39^{\prime \prime}$ & $90^{\circ} 24^{\prime} 6.59^{\prime \prime}$ \\
\hline
\end{tabular}




\begin{tabular}{|c|c|c|c|c|c|c|c|c|c|c|c|c|}
\hline L69 & $\begin{array}{l}\text { BAU, Sesh Matha } \\
\text { More }\end{array}$ & {$[1]$} & BAU Sadar & Mymensingh & Mymensingh & 14 Nov. 2016 & A03 & KY657502 & & MF345831 & $24^{\circ} 45^{\prime} 8.39^{\prime \prime}$ & $90^{\circ} 24^{\prime} 6.59^{\prime \prime}$ \\
\hline L70 & Nandail & {$[1]$} & Muktagacha & Mymensingh & Mymensingh & 30 Oct. 2016 & A03 & KY657503 & KY657505 & & $24^{\circ} 34^{\prime} 0^{\prime \prime}$ & $90^{\circ} 41^{\prime} 0^{\prime \prime}$ \\
\hline L71 & $\begin{array}{l}\text { Sarisha Bari High } \\
\text { School }\end{array}$ & {$[1]$} & Sarishabari & Jamalpulr & Mymensingh & 02 Nov. 2016 & A03 & KY657504 & KY657506 & MF345832 & $24^{\circ} 44^{\prime} 30^{\prime \prime}$ & $89^{\circ} 50^{\prime} 0^{\prime \prime}$ \\
\hline L71 & Bazar Pukur & {$[1]$} & Sarishabari & Jamalpur & Mymensingh & 02 Nov. 2016 & A03 & & KY65707 & MF345833 & $24^{\circ} 44^{\prime} 32^{\prime \prime}$ & $89^{\circ} 50^{\prime} 01^{\prime \prime}$ \\
\hline L72 & Sadar Hospital & {$[1]$} & $\begin{array}{l}\text { Netrokona } \\
\text { Sadar }\end{array}$ & Netrokona & Mymensingh & 03 Nov. 2016 & A03 & KY657494 & & MF345834 & $24^{\circ} 52^{\prime} 30^{\prime \prime}$ & $90^{\circ} 44^{\prime} 0^{\prime \prime}$ \\
\hline L72 & $\begin{array}{l}\text { Sadar Primary } \\
\text { School }\end{array}$ & {$[1]$} & $\begin{array}{l}\text { Netrokona } \\
\text { Sadar }\end{array}$ & Netrokona & Mymensingh & 04 Nov. 2016 & A03 & KY657495 & & MF345835 & $24^{\circ} 52^{\prime} 28^{\prime \prime}$ & $90^{\circ} 44^{\prime} 03^{\prime \prime}$ \\
\hline L73 & $\begin{array}{l}\text { Gauripur Upz } \\
\text { Complex }\end{array}$ & {$[1]$} & Gauripur & Mymensingh & Mymensingh & 10 Nov. 2016 & A03 & KY657496 & & & $24^{\circ} 45^{\prime} 30^{\prime \prime}$ & $90^{\circ} 34^{\prime} 30^{\prime \prime}$ \\
\hline L74 & Higher par & {$[2]$} & Kishorgonj & Kishorgonj & Mymensingh & 01 Nov. 2016 & A03 & KY657497 & & & $24^{\circ} 25^{\prime} 59.88$ & $90^{\circ} 46^{\prime} 59.88^{\prime \prime}$ \\
\hline L75 & Sadar Thana more & {$[1]$} & $\begin{array}{l}\text { Sherpur } \\
\text { Sadar }\end{array}$ & Sherpur & Mymensingh & 03 Nov. 2016 & A03 & KY657498 & & & $25^{\circ} 0^{\prime} 0^{\prime \prime}$ & $90^{\circ} 1^{\prime} 0^{\prime \prime}$ \\
\hline L76 & $\begin{array}{l}\text { Dhunat Upz. } \\
\text { Chattor }\end{array}$ & {$[1]$} & Dhunat & Bogra & Rajshahi & 04 Jan. 2018 & A01 & MG873538 & MG886852 & & $24^{\circ} 41^{\prime} 10.00^{\prime \prime}$ & $89^{\circ} 32^{\prime} 0.03^{\prime \prime}$ \\
\hline L77 & $\begin{array}{l}\text { Municipality } \\
\text { Orchard }\end{array}$ & {$[1]$} & $\begin{array}{l}\text { Naoga } \\
\text { Sadar }\end{array}$ & Naogaon & Rajshahi & 04 Jan. 2018 & A01 & MG873539 & MG886851 & & $24^{\circ} 48^{\prime} 18.00^{\prime \prime}$ & $88^{\circ} 57^{\prime} 0.18^{\prime \prime}$ \\
\hline L78 & Nijampur & {$[1]$} & Nachole & $\begin{array}{l}\text { Chapainawab } \\
\text { ganj }\end{array}$ & Rajshahi & 03 Jan. 2018 & A01 & MG873540 & MG886850 & & $24^{\circ} 43^{\prime} 48.03^{\prime \prime}$ & $88^{\circ} 25^{\prime} 12.13^{\prime \prime}$ \\
\hline L79 & $\begin{array}{l}\text { Hakimpur } \\
\text { Nursery }\end{array}$ & {$[1]$} & Hakimpur & Dinajpur & Rangpur & 29 Dec. 2017 & A01 & MG873541 & MG886847 & & $25^{\circ} 16^{\prime} 59.88^{\prime \prime}$ & $89^{\circ} 1^{\prime} 0.12^{\prime \prime}$ \\
\hline L80 & Shibpur & {$[1]$} & $\begin{array}{l}\text { Gabindagan } \\
\text { j sadar }\end{array}$ & Gaibandha & Rangpur & 02 Jan. 2018 & A01 & MG873542 & MG886849 & & $25^{\circ} 07^{\prime} 59.88^{\prime \prime}$ & $89^{\circ} 23^{\prime} 30.12^{\prime \prime}$ \\
\hline L81 & Gharialdanga & {$[1]$} & Rajarhat & Kurigram & Rangpur & 30 Dec. 2017 & A01 & MG873543 & & & $25^{\circ} 48^{\prime} 00^{\prime \prime}$ & $89^{\circ} 33^{\prime} 0.02^{\prime \prime}$ \\
\hline L82 & $\begin{array}{l}\text { Rasulpur School } \\
\text { ground }\end{array}$ & {$[1]$} & Pirganj & Rangpur & Rangpur & 27 Dec. 2017 & $\mathrm{~A} 01$ & MG873544 & MG886845 & & $25^{\circ} 24^{\prime} 54^{\prime \prime}$ & $89^{\circ} 19^{\prime} 0.10^{\prime \prime}$ \\
\hline L83 & $\begin{array}{l}\text { Saidpur airport } \\
\text { surrounding }\end{array}$ & {$[1]$} & Saidpur & Nilfamari & Rangpur & 01 Jan. 2018 & A01 & MG873545 & & & $25^{\circ} 47^{\prime} 0.04^{\prime \prime}$ & $88^{\circ} 54^{\prime} 0.02^{\prime \prime}$ \\
\hline L84 & Barobala & {$[1]$} & Mithapukur & Rangpur & Rangpur & 28 Dec. 2017 & A01 & MG873546 & MG886846 & & $25^{\circ} 32^{\prime} 30^{\prime \prime}$ & $89^{\circ} 17^{\prime} 0.00^{\prime \prime}$ \\
\hline L85 & $\begin{array}{l}\text { Pirganj fire station } \\
\text { orchard }\end{array}$ & {$[1]$} & Pirganj & Thakurgaon & Rangpur & 31 Dec. 2017 & A01 & MG873547 & MG886848 & & $25^{\circ} 51^{\prime} 15.12^{\prime \prime}$ & $88^{\circ} 22^{\prime} 0.12^{\prime \prime}$ \\
\hline L86 & $\begin{array}{l}\text { Debiganj bus } \\
\text { stand }\end{array}$ & {$[1]$} & Debiganj & Panchagar & Rangpur & 25 Dec. 2017 & A01 & MG873548 & MG886844 & & $26^{\circ} 07^{\prime} 9.89^{\prime \prime}$ & $88^{\circ} 45^{\prime} 33.47^{\prime \prime}$ \\
\hline L87 & $\begin{array}{l}\text { Atwari sadar } \\
\text { thana more }\end{array}$ & {$[1]$} & Atwari & Panchagar & Rangpur & 26 Dec. 2017 & A01 & MG873549 & & & $26^{\circ} 18^{\prime} 29.88^{\prime \prime}$ & $88^{\circ} 27^{\prime} 29.88^{\prime \prime}$ \\
\hline
\end{tabular}

